\title{
ENVIRONMENTAL ASSESSMENT Of Remedial Action AT the Naturita URANIUM Processing Site Near Naturita, Colorado
}

\section{October 1994}

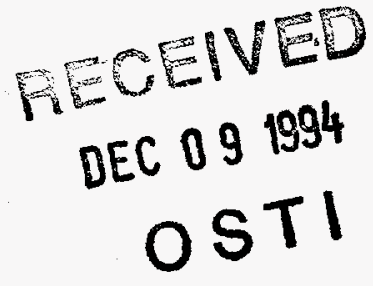

\section{DISCLAIMER}

This report was prepared as an account of work sponsored by an agency of the United States Government. Neither the United States Government nor any agency thereof, nor any of their employees, makes any warranty, express or implied, or assumes any legal liability or responsibility for the accuracy, completeness, or usefulness of any information, apparatus, product, or process disclosed, or represents that its use would not infringe privately owned rights. Reference herein to any specific commercial product, process, or service by trade name, trademark, manufacturer, or otherwise does not necessarily constitute or imply its endorsement, recommendation, or favoring by the United States Government or any agency thereof. The views and opinions of authors expressed herein do not necessarily state or reflect those of the United States Government or any agency thereof. 
This report has been reproduced from the best available copy. Available in paper copy and microfiche.

Number of pages in this report: 179

DOE and DOE contractors can obtain copies of this report from:

Office of Scientific and Technical Information

P.O. Box 62

Oak Ridge, TN 37831

(615) 576-8401

This report is publicly available from:

National Technical Information Service

Department of Commerce

5285 Port Royal Road

Springfield, VA 22161

(703) $487-4650$ 


\section{DISCLAIMER}

Portions of this document may be illegible in electronic image products. Images are produced from the best available original document. 


.




\section{ENVIRONMENTAL ASSESSMENT OF REMEDIAL ACTION} AT THE NATURITA URANIUM PROCESSING SITE NEAR NATURITA, COLORADO

October 1994

Prepared for

U.S. Department of Energy UMTRA Project Office Albuquerque, New Mexico

Prepared by Jacobs Engineering Group Inc. Albuquerque, New Mexico 


\section{TABLE OF CONTENTS}

Section

Page

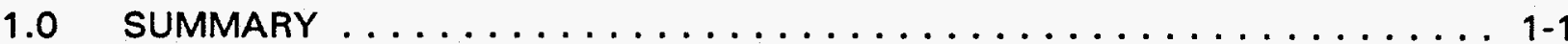

2.0 INTRODUCTION ........................... 2-1

2.1 Background .......................... $2-1$

2.2 Descriptions of the processing and disposal sites ... . . . . . . 2-2

2.2.1 Naturita processing site . . . . . . . . . . . . . 2-2

2.2.2 Uravan disposal site ................... 2-5

2.2.3 Dry Flats disposal site . . . . . . . . . . . . . . . . . 2-5

2.3 Comments on the draft environmental assessment . . . . . . . . . 2-5

2.4 Alternatives to the proposed action . . . . . . . . . . . . . . 2-9

2.4.1 No action ......................... 2.9

2.4.2 Alternatives no longer under consideration ........... 2-9

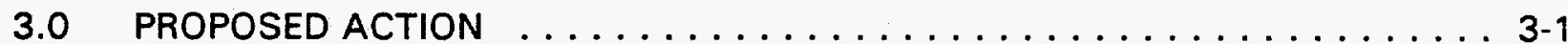

3.1 Description of the proposed action $\ldots \ldots \ldots \ldots \ldots \ldots \ldots \ldots \ldots$

3.1 .1 Uravan disposal alternative ................ 3-2

3.1.2 Dry Flats disposal alternative . . . . . . . . . . . . . 3-3

3.2 Borrow sites . . . . . . . . . . . . . . . . . . $3-6$

3.2.1 Uravan disposal alternative .............. 3-6

3.2.2 Dry Flats disposal alternative . . . . . . . . . . . . 3-6

3.3 Transportation routes . . . . . . . . . . . . . . . 3-7

3.3.1 Uravan disposal alternative ............... 3-7

3.3.2 Dry Flats disposal alternative . . . . . . . . . . . . . . 3-9

3.4 Conformance to land use plans and policies . . . . . . . . . . . 3-10

3.5 Compliance with EPA standards . . . . . . . . . . . . . . 3-10

4.0 AFFECTED ENVIRONMENT $\ldots \ldots \ldots \ldots \ldots \ldots \ldots \ldots \ldots \ldots \ldots \ldots \ldots$

4.1 Climate and air quality . . . . . . . . . . . . . . . 4-1

4.2 Geology and soils ......................... 4-2

4.3 Surface water and flood hazard . . . . . . . . . . . . . . . . . 4-4

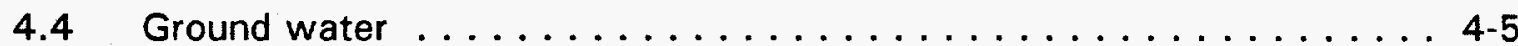

4.4.1 Naturita processing site . . . . . . . . . . . . 4 4-5

4.4.2 Uravan disposal site . . . . . . . . . . . . 4 4-7

4.4.3 Dry Flats disposal site . . . . . . . . . . . . . . 4-8

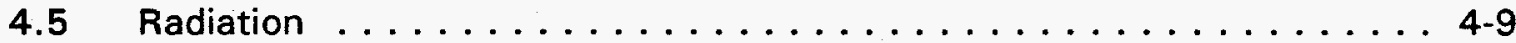

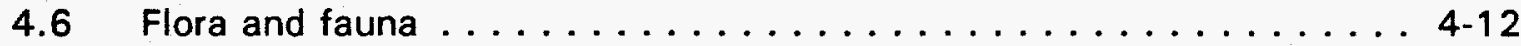

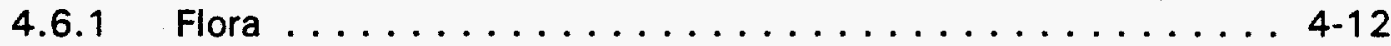

4.6 .2 Fauna .......................... 4.13

4.6.3 Threatened and endangered species . . . . . . . . . . . . 4-14

4.7 Land use . . . . . . . . . . . . . . . . . . . . . 4-15

4.8 Historical and cultural resources . . . . . . . . . . . . . 4-17

4.9 Socioeconomic characteristics .................. 4-18

4.10 Transportation .......................... 4-19 


\section{TABLE OF CONTENTS (Concluded)}

Section

Page

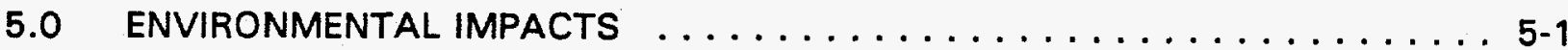

5.1 Introduction and assumptions ................. $5-1$

5.2 No action . . . . . . . . . . . . . . . . . . . $5-1$

5.3 General impact summary ...................... 5-2

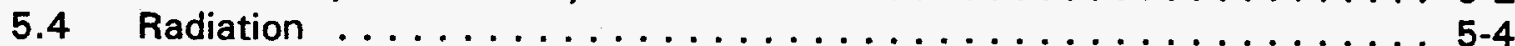

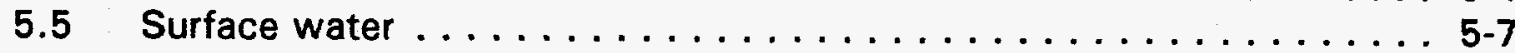

5.6 Ground water . . . . . . . . . . . . . . . . . . . $5-8$

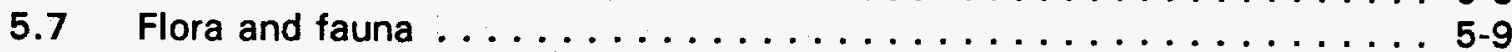

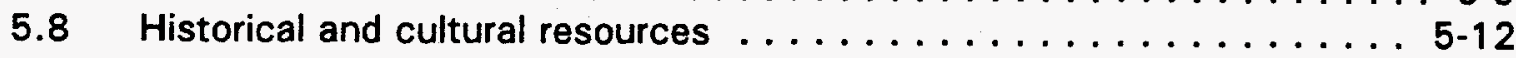

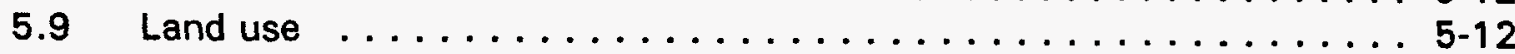

5.10 Socioeconomics ........................ 5-15

5.11 Transportation ........................ 5-17

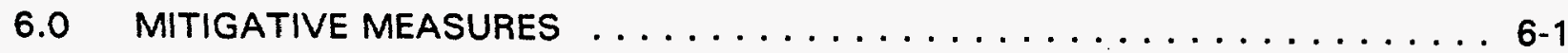

7.0 CONSULTATION AND COORDINATION $\ldots \ldots \ldots \ldots \ldots \ldots \ldots$

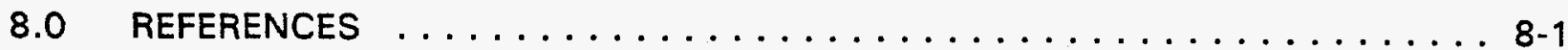

ATTACHMENT 1 FLOODPLAINS AND WETLANDS ASSESSMENT

ATTACHMENT 2 BIOLOGICAL ASSESSMENT 


\section{LIST OF FIGURES}

Figure

2.1 Location of the Naturita site, Colorado . . . . . . . . . . . . . . . . 2-3

2.2 Present conditions at the Naturita site, Colorado . . . . . . . . . . . . . 2-4

2.3 Uravan disposal facility map, Montrose County, Naturita site, Colorado . . . . . 2-6

2.4 Location of the Dry Flats disposal site, Colorado . . . . . . . . . . . . . . 2-7

3.1 Final conditions at the Dry Flats disposal site, Colorado . . . . . . . . . . 3-4

3.2 Typical cross section of the Dry Flats disposal site. Colorado . . . . . . . . . 3-5

4.1 Extent of contamination at the Naturita site, Colorado . . . . . . . . . . . 4-10

\section{LIST OF TABLES}

Table

Page

5.1 Excess health effects for the general public and remedial action workers ${ }^{a} \ldots$ 5-5 


\section{LIST OF ACRONYMS AND ABBREVIATIONS}

\section{Acronym Definition}

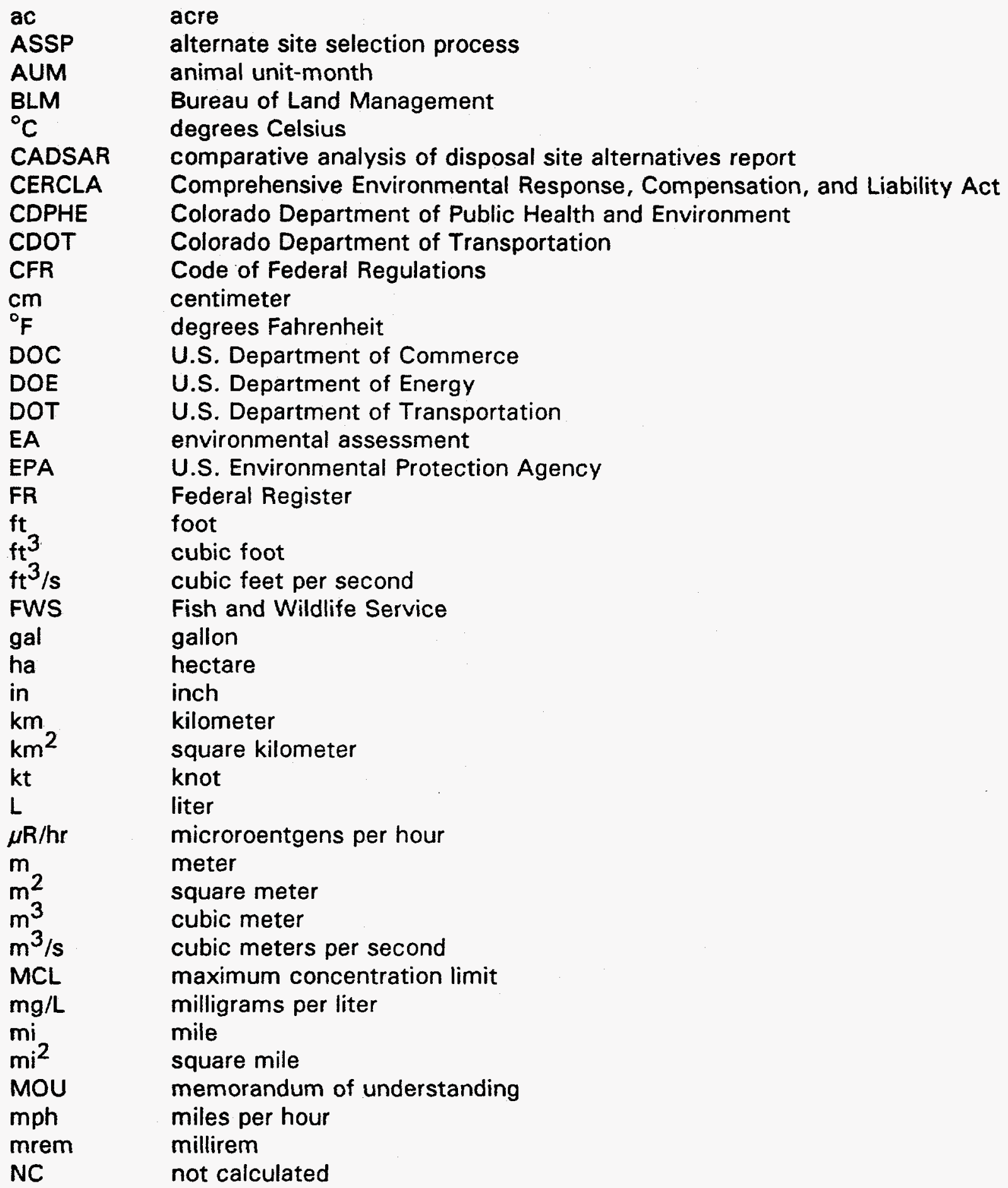


LIST OF ACRONYMS AND ABBREVIATIONS (Concluded)

\section{Acronym Definition}

$\begin{array}{ll}\text { NEPA } & \text { National Environmental Policy Act } \\ \text { NMPM } & \text { New Mexico Principal Meridian } \\ \text { NRC } & \text { U.S. Nuclear Regulatory Commission } \\ \text { NRHP } & \text { National Register of Historic Places } \\ \text { pCi } & \text { picocurie } \\ \text { pCi/g } & \text { picocuries per gram } \\ \text { pCi/m } 2 \text { s } & \text { picocuries per square meter per second } \\ \text { pCi/L } & \text { picocuries per liter } \\ \text { PL } & \text { public law } \\ \text { PMP } & \text { probable maximum precipitation } \\ \text { Ra-226 } & \text { radium-226 } \\ \text { RAC } & \text { Remedial Action Contractor } \\ \text { RCD } & \text { Radiation Control Division } \\ \text { REA } & \text { radiological and engineering assessment } \\ \text { ROW } & \text { right-of-way } \\ \text { RRM } & \text { residual radioactive materials } \\ \text { SHPO } & \text { State Historic Preservation Officer } \\ \text { TDS } & \text { total dissolved solids } \\ \text { Th-232 } & \text { thorium-232 } \\ \text { TSP } & \text { total suspended particulates } \\ \text { UMTRA } & \text { Uranium Mill Tailings Remedial Action } \\ \text { UMTRCA } & \text { Uranium Mill Tailings Radiation Control Act of 1978 } \\ \text { USACE } & \text { U.S. Army Corps of Engineers } \\ \text { USGS } & \text { U.S. Geological Survey } \\ \text { Yd } & \text { yard } \\ \text { Yd } & \text { cubic yard } \\ & \end{array}$




\subsection{SUMMARY}

Title I of the Uranium Mill Tailings Radiation Control Act (UMTRCA) of 1978, Public Law (PL) 95-604, authorized the U.S. Department of Energy (DOE) to perform remedial action at the inactive Naturita, Colorado, uranium processing site (as well as at many other inactive sites) to reduce the potential health effects from the radioactive materials at the site and at vicinity properties associated with the site. Title II of the UMTRCA authorized the U.S. Nuclear Regulatory Commission (NRC) or agreement state to regulate the operation and eventual reclamation of active uranium processing sites. The U.S. Environmental Protection Agency (EPA) promulgated standards for remedial actions at the inactive (Title I) and active (Title II) uranium processing sites in Title 40, Code of Federal Regulations, Part 192, Subparts A through E (40 CFR Part 192, Subparts A through E). Remedial action at the Naturita site must be performed in accordance with the EPA standards for inactive (Title I) processing sites (40 CFR Part 192, Subparts A, B, and C) and with the concurrence of the NRC and the state of Colorado.

Residual radioactive materials (RRM) at the Naturita processing site cover an estimated 50 acres (ac) [20 hectares (ha)] within the 53-ac (21-ha) designated site and approximately 194 ac $(79 \mathrm{ha})$ adjacent to the site. The uranium mill tailings at the site were removed and reprocessed from 1977 to 1979 . The contaminated areas include the former tailings area, the mill yard, the former ore storage area, and adjacent areas that were contaminated by uranium processing activities and wind and water erosion. The estimated volume of contaminated materials at and adjacent to the Naturita site is 534,000 cubic yards ( $\mathrm{yd}^{3}$ ) $\left[408,000\right.$ cubic meters $\left.\left(\mathrm{m}^{3}\right)\right]$, and there are approximately $8000 \mathrm{yd}^{3}\left(6100 \mathrm{~m}^{3}\right)$ of contaminated debris (e.g., buildings and mill equipment) at the site. In addition, there are approximately $400 \mathrm{yd}^{3}\left(310 \mathrm{~m}^{3}\right)$ of contaminated materials at 21 properties in nearby communities (vicinity properties).

The proposed remedial action for the Naturita processing site is relocation of the RRM to the Uravan disposal site, approximately 13 road miles (mi) [21 kilometers $(\mathrm{km})$ ] to the northwest. At the Uravan disposal site, the RRM would be stabilized and covered with layers of earth and rock. The Uravan site is currently licensed for the disposal of up to 900,000 dry tons $\left(750,000 \mathrm{yd}^{3}\right)$ of Naturita UMTRCA Title I material by the Colorado Department of Public Health and Environment (CDPHE). The DOE's Uranium Mill Tailings Remedial Action (UMTRA) Project would be responsible for transporting the RRM from the Naturita processing site to the Uravan site and for completing the remedial action at the processing site in accordance with the EPA standards for inactive uranium processing sites (40 CFR Part 192, Subparts A, B and C). The disposal at the Uravan site would be consistent with the EPA standards for active uranium processing sites (40 CFR Part 192) and other appropriate authorizations and would be performed in accordance with a disposal plan prepared by the owner and operator of the site and approved by the CDPHE Radiation Control Division (RCD).

An alternate disposal site, Dry Flats, located 6 road $\mathrm{mi}(10 \mathrm{~km})$ to the southeast, has been fully evaluated in this environmental assessment (EA) and will serve as a contingency option should legal, technical, or contractual issues preclude the DOE from disposing of the RRM at Uravan. The Dry Flats disposal site is on land administered by the Bureau of Land 
Management (BLM) and used primarily for livestock grazing. The final Dry Flats site would cover approximately 57 ac ( $23 \mathrm{ha}$ ), which would be permanently transferred from the BLM to the DOE and restricted from future uses. The remedial action would be conducted by the DOE's UMTRA Project and would be consistent with the EPA standards for inactive (Title I) uranium processing sites.

The Naturita remedial action would result in the loss of $133 \mathrm{ac}$ ( $55 \mathrm{ha}$ ) of contaminated soils at the processing site. If supplemental standards are approved by the NRC and the state of Colorado, approximately 112 ac ( $45 \mathrm{ha}$ ) of steeply sloped contaminated soils adjacent to the processing site would not be cleaned up. Cleanup of this contamination would have adverse environmental consequences and would be potentially hazardous to remedial action workers. Applying supplemental standards to other areas surrounding the site could also reduce other environmental impacts, such as the disturbance of cultural resources and riparian plant communities.

Removal of the contaminated materials at and adjacent to the Naturita processing site would slightly affect the 100-year floodplain of the San Miguel River and possibly along Dry Creek. Approximately 5 ac (2 ha) of the riparian plant communities meet the U.S. Army Corps of Engineers (USACE) definition of a wetland.

The southwestern willow flycatcher has been proposed as endangered. The willow flycatcher was present in the area of the processing site in 1986, but it has not been recorded at the site during surveys in 1990 through 1994. The use of water from the San Miguel River for the remedial action "may affect" the endangered Colorado squawfish, humpback chub, bonytail chub, and razorback sucker and may have an adverse effect on the critical habitat of these fish species.

The Uravan disposal site would not require construction of new roads, a new disposal cell, or the land use and cultural resource impacts associated with them. Use of the Uravan alternative would increase traffic and noise levels on Colorado State Highway 141 between the mill site and Uravan and could increase traffic and noise levels on other state highways and county roads based on the location of the borrow source selected to provide fill material for the remediated mill site.

The Dry Flats disposal site would result in approximately 57 ac (23 ha) of BLM land being permanently removed from livestock grazing and wildlife use. Another 220 ac (89 ha) of soils on BLM-administered lands would be temporarily disturbed during the remedial action. The Dry Flats disposal alternative could affect historical and cultural resources in the area and create a strain on local housing due to the influx of construction personnel and increase traffic and noise levels on Colorado State Highways 90 and 141 . There would also be land use impacts associated with the temporary disturbance of BLM grazing land at the Coke Oven borrow area

Measures for mitigating the adverse environmental impacts of the proposed remedial action are discussed in this EA. 
The environmental benefits associated with the proposed remedial action include a reduction in the risk of potential health effects related to the Naturita RRM; the availability of the processing site for productive future use; and a short-term increase in local expenditures and possibly employment.

Based on the analysis in this EA, the proposed remedial action of off-site disposal of contaminated materials at either the Uravan or the Dry Flats disposal sites does not constitute a major federal action significantly affecting the quality of the human environment, within the meaning of the National Environmental Policy Act (NEPA). However, the DOE favors use of the Uravan site because it would 1) result in fewer environmental impacts (i.e. eliminate the need to construct a new disposal cell and haul road and the need to borrow soil from the Coke Oven sitel; 2) create less strain on local housing; and 3 ) be implementable at a lower cost.

For more information, contact

\author{
Charles A. Cormier \\ Acting Project Manager \\ Uranium Mill Tailings Remedial Action Project \\ U.S. Department of Energy \\ UMTRA Project Office
}

2155 Louisiana Blvd. N.E. Suite 4000

Albuquerque, New Mexico 87110-5414

(505) $845-4628$ 


\subsection{INTRODUCTION}

\section{$2.1 \quad$ BACKGROUND}

In response to concern about the potential public health hazards related to uranium mill tailings and the associated contaminated materials left abandoned or otherwise uncontrolled at inactive processing sites throughout the United States, Congress passed the UMTRCA, PL 95-604, on November 8, 1978. In the UMTRCA, Congress acknowledged that potential health hazards are associated with uranium mill tailings and identified a number of sites that were in need of remedial actions. The inactive Naturita uranium processing site is one of these sites.

Uranium mill tailings are the residues of uranium ore processing operations. They consist of finely ground rock, similar to sand. The tailings were removed from the Naturita processing site between 1977 and 1979, but RRM remain at and adjacent to the site. The principal potential hazard associated with the RRM results from the production of radon, a radioactive gas formed from the radioactive decay of the radium contained in the RRM. Radon can move through the tailings into the air. Increased exposure to radon and its decay products over an extended time period increases the probability that health effects (i.e., cancers) may develop in persons living and working near the RRM. Another hazard is associated with radioactive and other hazardous constituents leaching out of the RRM through the underlying soils to contaminate ground water. Exposure to gamma radiation, the inhalation and ingestion of airborne radioactive particulates, the ingestion of food grown in contaminated soil in areas around the processing site, and the ingestion of surface waters and ground waters contaminated by the materials also pose potential hazards. If the RRM are not properly stabilized, natural processes such as wind and water erosion or removal of the materials by the general public could spread the contamination and increase the potential for public health hazards.

Title I of the UMTRCA authorized the DOE to perform remedial action at the inactive Naturita processing site (as well as at the 23 other inactive sites identified in the UMTRCA) to reduce the potential public health impacts from the RRM remaining at the site. Title II of the UMTRCA authorized the NRC or agreement state to regulate the operation of active uranium processing sites. An agreement state is a state that regulates the active processing sites within its boundaries in accordance with NRC regulations through a cooperative agreement with the NRC. Following the cessation of processing activities, remedial actions at the active (Title II) processing sites are the responsibilities of the site owners and operators pursuant to remedial action or disposal plans approved by the NRC or agreement states. All remedial actions at the inactive (Title I) and active (Title II) processing sites must be completed in accordance with standards promulgated by the EPA. 
The EPA promulgated standards for remedial actions at the inactive (Title I) and active (Title II) uranium processing sites in 40 CFR Part 192, Subparts $A$ through E. The standards for inactive sites in Subparts A, B, and C became effective March 3, 1983; the standards for active sites in Subparts $D$ and $E$ became effective December 6,1983 . The EPA standards are essentially the same for the inactive and active sites.

On September 3, 1985, the U.S. Court of Appeals for the Tenth Circuit remanded the EPA ground water protection standards for the inactive (Title I) uranium processing sites [40 CFR Part 192.20(a)(2) and (3)]. The EPA subsequently proposed new ground water standards [52 Federal Register (FR) 36000; September 24, 19871 that, although not final at the time of this writing, are nonetheless applicable to the remedial action at the Naturita site. Compliance with the proposed standards is considered in this EA; however, the need for ground water remediation at the processing site will be evaluated during the ground water restoration phase of the UMTRA Project.

\subsection{DESCRIPTIONS OF THE PROCESSING AND DISPOSAL SITES}

\subsubsection{Naturita processing site}

The Naturita processing site is in Sections 14 and 15, Township 46 North, Range 16 West (Secs. 14 and 15, T46N, R16W). New Mexico Principal Meridian (NMPM) in Montrose County, Colorado. The site is approximately 2 road $\mathrm{mi}(3 \mathrm{~km})$ northwest of the unincorporated town of Naturita (Figure 2.1). The site is on the west bank of the San Miguel River, a perennial tributary of the Dolores River. The majority of the designated site is privately owned, but a small portion of the site is on land administered by the BLM. The area around the designated site contains privately owned and BLM-administered lands.

The Naturita mill was built in 1930 and became operational in 1939 when it was modified for the recovery of vanadium. It was modified again in 1942 for the recovery of both uranium and vanadium. The mill was shut down from 1945 to 1947 . Uranium milling resumed in 1947 and continued until 1958; the mill was shut down again from 1958 to 1961 . An upgrader plant was operated at the site from late 1961 to early 1963. The mill was shut down and dismantled in 1963. Between 1977 and 1979, the tailings at the site were removed and reprocessed at a new facility approximately 3 air $\mathrm{mi}(5 \mathrm{~km})$ to the south. After being reprocessed, the tailings were stabilized at the new facility (FBDU, 1981).

The designated Naturita site covers 53 ac ( 21 ha) and contains the former tailings area, mill yard, and part of the former ore storage area (Figure 2.2). There are no tailings at the site, but there are $116,900 \mathrm{yd}^{3}\left(89,400 \mathrm{~m}^{3}\right)$ of contaminated materials in the $27-a c(11-$ ha) area of the former tailings pile. The 12 -ac (5-ha) mill yard contains $114,700 \mathrm{yd}^{3}\left(87,700 \mathrm{~m}^{3}\right)$ of contaminated soil, and the former ore storage area $\left[12 \mathrm{ac}\left(5\right.\right.$ ha)] contains $11,600 \mathrm{yd}^{3}\left(8900 \mathrm{~m}^{3}\right)$ of contaminated soil. Tailings have been dispersed by uranium processing 


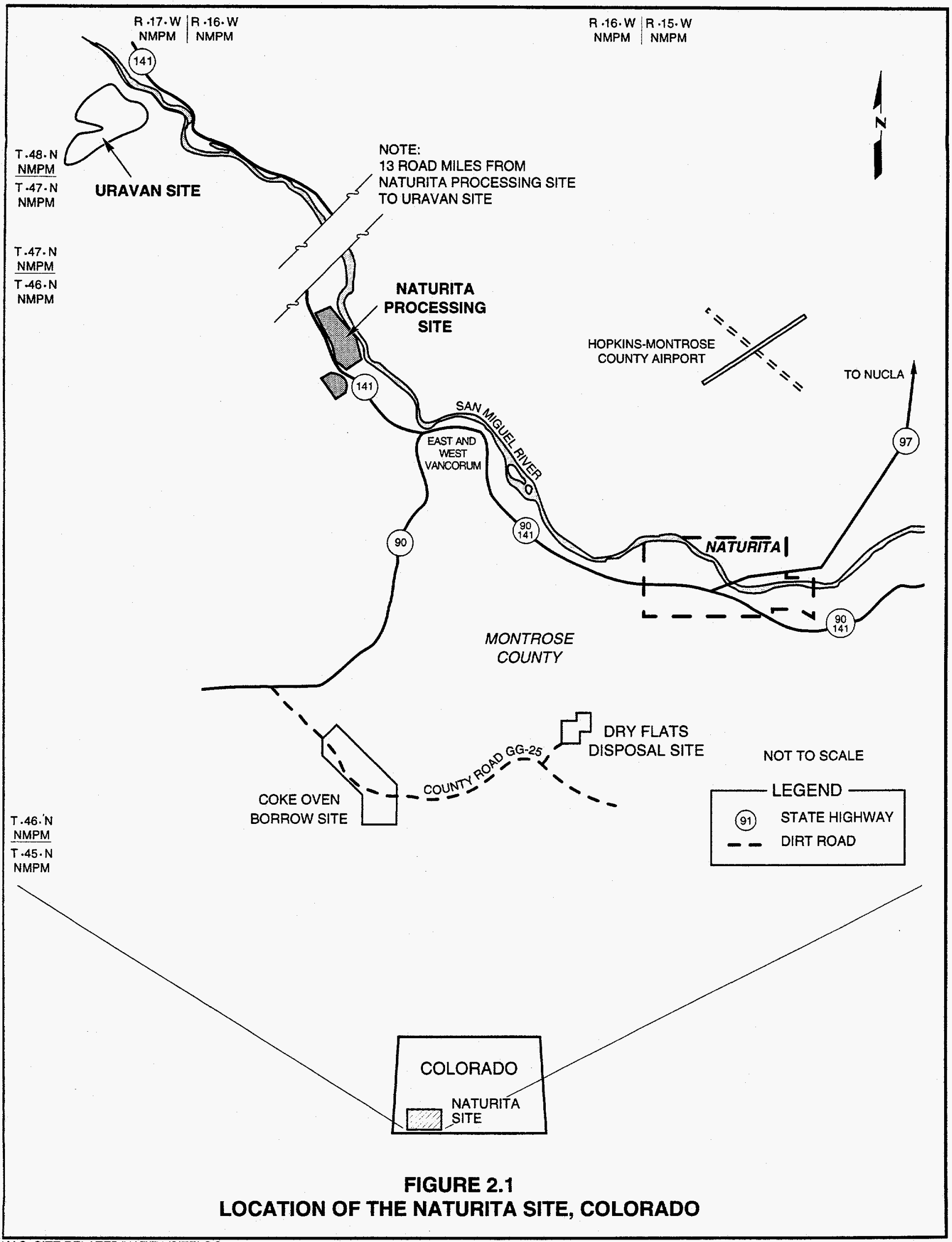




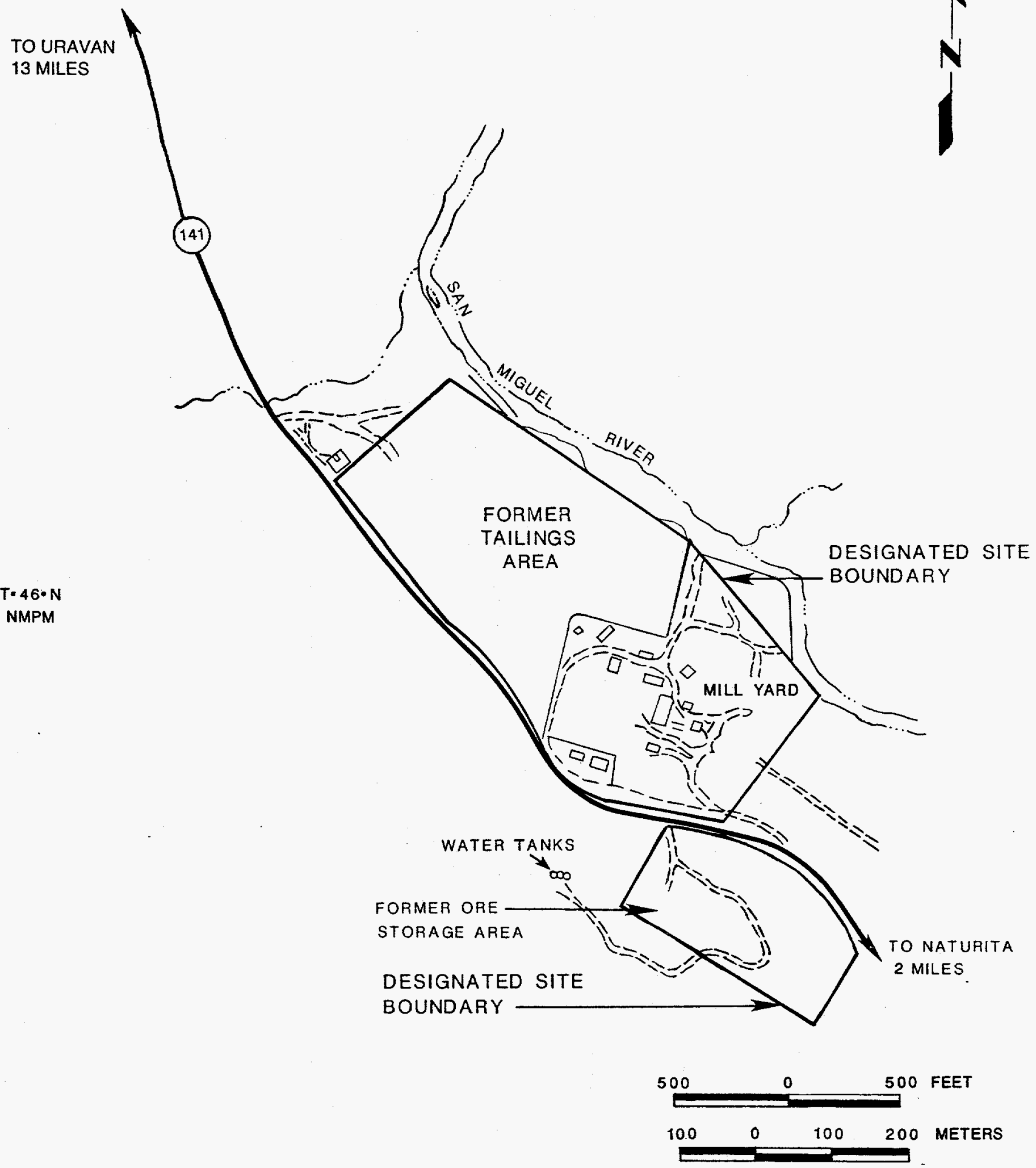

FIGURE 2.2

P.RESENT CONDITIONS AT THE NATURITA SITE, COLORADO 
activities and wind and water erosion and have contaminated $290,800 \mathrm{yd}^{3}$ $\left(222,300 \mathrm{~m}^{3}\right)$ of soil covering 194 ac (79 ha) adjacent to the designated site. The total estimated volume of contaminated materials is 534,000 $\mathrm{yd}^{3}$ $\left(408,300 \mathrm{~m}^{3}\right)$, and there are $8000 \mathrm{yd}^{3}\left(6100 \mathrm{~m}^{3}\right)$ of contaminated debris (buildings, foundations, and abandoned construction and mill equipment) at the site. In addition, there are approximately $400 \mathrm{yd}^{3}\left(310 \mathrm{~m}^{3}\right)$ of contaminated materials at 21 off-site vicinity properties in East Vancorum and Naturita (Figure 2.1). Vicinity properties are properties located outside the designated site boundary that have been contaminated by tailings. The tailings may have been dispersed by wind or water erosion or removed by people before the potential hazards of the tailings were known.

\subsubsection{Uravan disposal site}

The Uravan disposal site at Uravan, Colorado, is in Sec. 4, T47N, R17W, and Secs. $28,29,33$, and $34, T 48 N, R 17 W$. The Uravan site is approximately 13 road mi $(21 \mathrm{~km})$ northwest of the Naturita processing site via Colorado State Highway 141 (Figures 2.1 and 2.3). The site is situated on two benches of Club Mesa approximately 400 feet $(\mathrm{ft})$ [122 meters $(\mathrm{m})]$ above the San Miguel River. The Uravan site is currently licensed for the disposal of radioactive materials (Colorado Radioactive Material License \#660-02) by the CDPHE/RCD. The site is also a Superfund site and is being reclaimed under the Comprehensive Environmental Response, Compensation, and Liability Act (CERCLA) and a court decree between the site owner and the state of Colorado. Since operations began at the Uravan facility in the 1950 s, over 10 million tons (9.1 million tonnes) of tailings, millions of gallons of waste liquid raffinate, raffinate crystal residue, and other milling wastes containing radioactive materials, metals, and other inorganic contaminants have been produced and are scheduled to be placed in repositories currently under construction at the site.

\subsubsection{Dry Flats disposal site}

The Dry Flats disposal site is in Secs. 25 and 36, T46N, R16W, NMPM, on a broad mesa that dips gently to the northeast. The site is 6 road mi $(10 \mathrm{~km})$ southeast of the Naturita processing site via Colorado State Highways 141 and 90 and County Road GG-25 (Figures 2.1 and 2.4). The Dry Flats site and surrounding land are administered by the BLM and are used primarily for livestock grazing. Section 4.7, Land Use, provides details on land use at and around the Dry Flats disposal site. The Dry Flats disposal site will serve as a contingency option should legal, technical, or contractual issues preclude the DOE from disposing of the RRM at Uravan.

\subsection{COMMENTS ON THE DRAFT ENVIRONMENTAL ASSESSMENT}

An EA of the proposed remedial action at the Naturita processing site was prepared in 1990. Comments on the EA were received from the EPA, BLM, CDPHE, Fish and Wildlife Service (FWS), UMTRA Project Naturita Citizens Advisory Committee, and Office of Environmental Management of the DOE. 


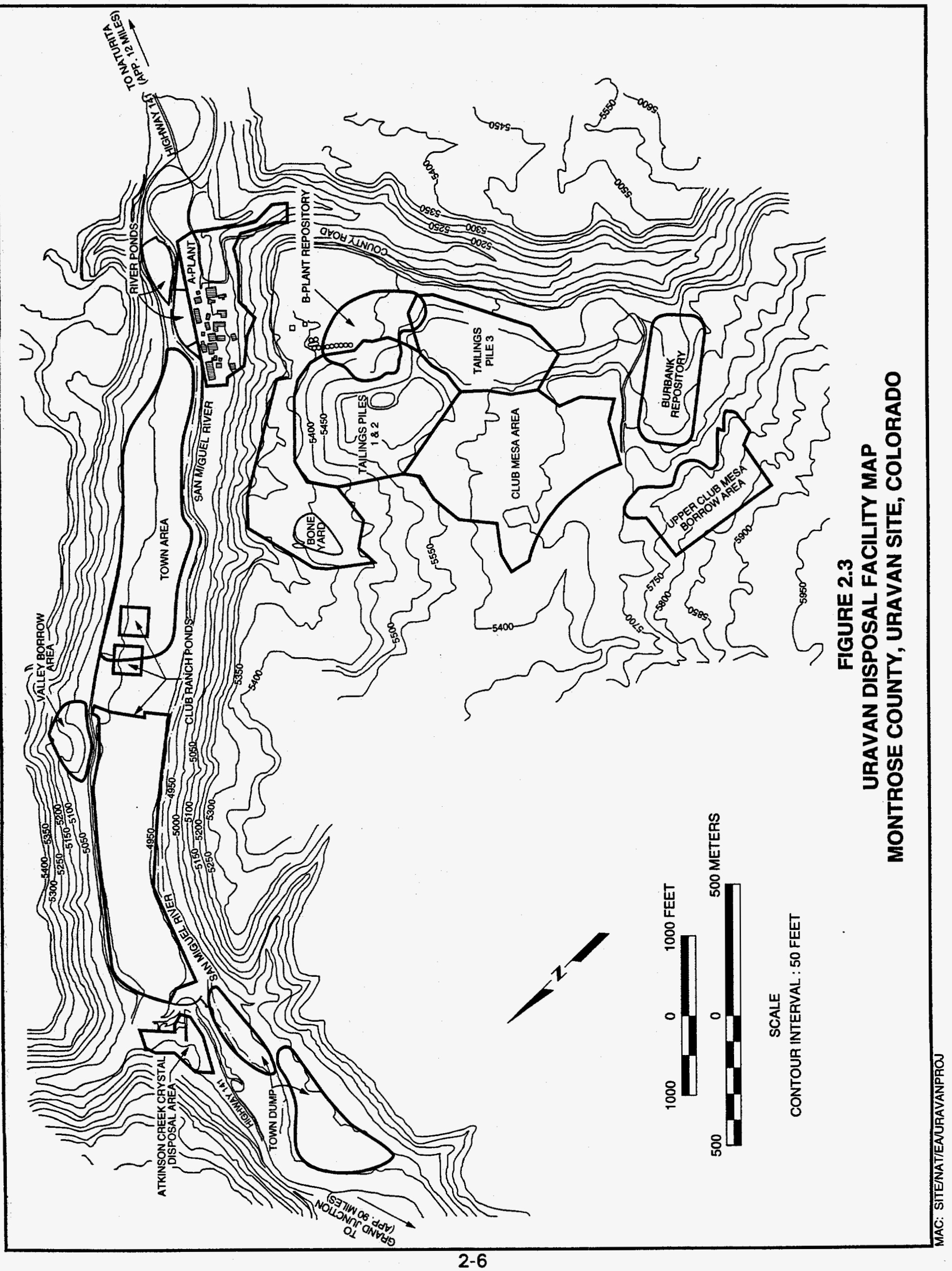




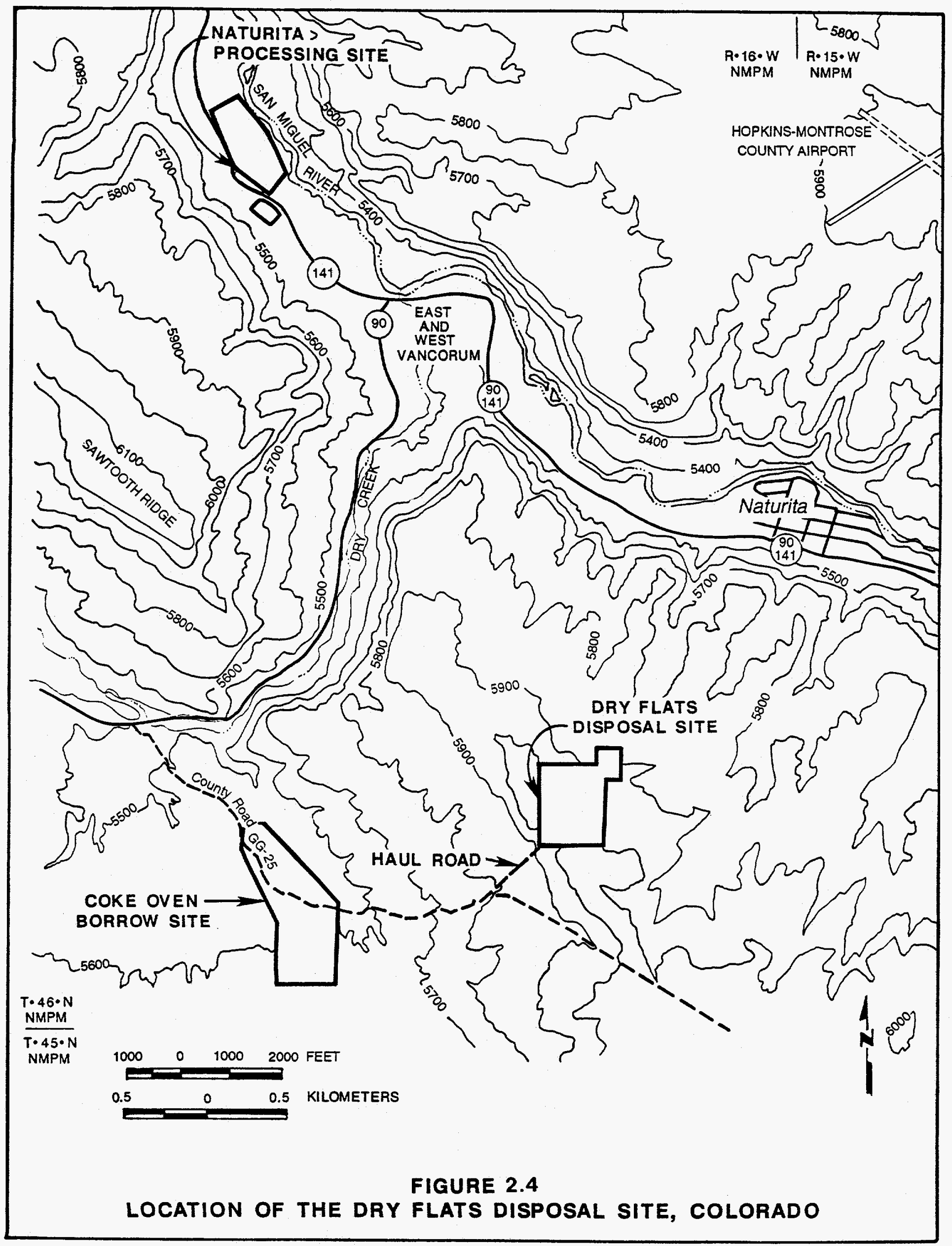


The major concerns expressed in those comments are summarized below.

- The EA should include the relocation of the Naturita RRM to an existing mill tailings site at Uravan, Colorado, as another remedial action alternative.

- A better characterization of existing ground water and geochemical conditions at the Dry Flats disposal site should be provided in the EA. Potential ground water contamination due to the proposed remedial action should be fully addressed in the EA.

- Updated and/or additional information on flora and fauna and threatened and endangered species should be included in the EA.

- Details in the EA should be verified (e.g., the total volume of contaminated materials), and additional details on various subjects (e.g., permanent withdrawal of the disposal site and land use) should be included in the EA.

- The EA should include a section on cumulative environmental impacts for other projects in the Naturita area.

The EA of the proposed Naturita remedial action was revised in August 1993. All of the comments received on the 1990 EA were considered in the revision of the EA, and changes in the design of the Dry Flats disposal alternative were incorporated in the EA. In addition, the revised EA contained a more concise and focused evaluation of the environmental impacts, and the discussions of issues related to remedial action activities on BLM-administered lands were closely coordinated with the BLM. Comments on the revised EA were received from the EPA, BLM, FWS, CDPHE, UMTRA Project Naturita Citizens Advisory Committee, and DOE. The major concerns expressed in these comments are summarized below.

- The EA should provide a better description of the process used to evaluate and reject remedial action alternatives.

- Additional support for the absence of mineral resources at the Dry Flats disposal site should be provided in the EA.

- The difference between the terms "riparian habitat" and "wetlands" should be specified in the EA. The mitigation of impacts to wetlands through the USACE 404 Permit process should be clarified in the EA.

- The EA should more adequately address the socioeconomic impacts of the proposed remedial action (e.g., impacts to housing and schools in the Naturita areal.

- An Air Pollution Emissions Notice and Emission Permit from the state of Colorado would require that a dust control plan be implemented before the start of the remedial action. 
- The EA should specify that there would be an appreciable increase in traffic during the remedial action, but the increase would be for a short duration.

- Impacts to the southwestern willow flycatcher, prairie dogs, and endangered fish species should be clarified in the EA.

- Land ownership at the Naturita processing site should be clarified in the EA, and the process for implementing supplemental standards should be included in the EA.

- The EA should describe the various rights-of-way (ROW) that would be required for the remedial action activities at the Dry Flats disposal site. The amounts of surface disturbance caused by specific remedial action activities (e.g., road improvement and disposal cell construction) should be clarified in the EA.

In early 1994, the CDPHE submitted additional comments on the revised EA, and the DOE decided to consider the disposal of the Naturita RRM at the Uravan disposal site at Uravan, Colorado. All of the comments received on the August 1993 revised EA were considered in another revision of the EA, and the disposal of the Naturita RRM at the Uravan site was included as a disposal alternative. In addition, the DOE has maintained close communication with the involved parties through an established public information program and the remedial action process.

\subsection{ALTERNATIVES TO THE PROPOSED ACTION}

\subsubsection{No action}

The no action alternative consists of taking no steps toward the remediation of the Naturita processing site. The BLM could deny approval for the Dry Flats disposal alternative and could deny all permits associated with using the identified sites and roads on BLM-administered land; thus, no public lands would be disturbed. The owner of the Uravan site may withdraw its acceptance of the Naturita RRM or the Uravan site may not be selected by the DOE. The Naturita RRM would remain where they are currently located until the DOE could identify another suitable disposal site. The selection of this alternative would not be consistent with the intent of Congress in the UMTRCA and would not result in compliance with the EPA standards.

\subsubsection{Alternatives no longer under consideration}

The DOE performed two comparative analyses of disposal site alternatives to select a preferred remedial action for the Naturita processing site. These analyses included the evaluation of technical, environmental, and cost factors as well as the risks associated with each disposal site alternative. Technical factors included disposal site stability and ground water conditions, and environmental factors included the presence of threatened and endangered 
species and the proximity of residences and population centers. Cost factors included special design features (e.g., costs of special erosion protection measures) and haulage distances for both contaminated materials and borrow materials. Risks were evaluated for each alternative by probability and included disposal site stability, erosion potential, and ground water conditions. The state of Colorado and NRC were consulted during these analyses, and the results of the analyses are provided in the draft and final comparative analysis of disposal site alternatives reports (CADSAR) for the Naturita site (DOE, 1986; 1988a).

\section{First comparative analysis of disposal site alternatives}

During the first comparative analysis of disposal site alternatives (DOE, 1986), four alternatives for the disposal of the Naturita RRM were identified. The first alternative was to stabilize the RRM at the Naturita processing site. Two other alternatives were to relocate the RRM to the Coke Oven site or to the adjacent Durita Facility, a Title II uranium processing facility that has ceased operations. These sites are approximately 5 road mi $(8 \mathrm{~km})$ south of the Naturita site. The fourth alternative was to consolidate and stabilize the Naturita RRM with the tailings and contaminated materials at the Slick Rock UMTRA Project site approximately 45 road $\mathrm{mi}(72 \mathrm{~km})$ southwest of the Naturita site.

Two conceptual designs for the disposal of the RRM at the Naturita processing site were evaluated. While these design alternatives might be cheaper and quicker than relocating all of the RRM, they were found to be technically and environmentally unsuitable. Therefore, disposal at the Naturita processing site was not considered to be a viable remedial action alternative. The conceptual designs for disposal at the Coke Oven site. Durita Facility, and Slick Rock, Colorado, UMTRA Project site were similar to the conceptual designs for disposal at the Naturita site, except that all of the RRM would be relocated from the processing site to a more remote disposal site. At each disposal site, the RRM would be stabilized in a disposal cell that would be designed for long-term stability and radiation protection in accordance with the EPA standards. The Durita Facility alternative would be more expensive than the Coke Oven alternative but cheaper than the Slick Rock alternative. However, the comparative analysis showed that these alternatives would not be technically and environmentally suitable. The first comparative analysis of disposal site alternatives resulted in various recommendations for activities that should be undertaken to prepare the final CADSAR and to provide the information necessary to select a preferred remedial action for the Naturita processing site.

Subsequent to the first comparative analysis, a remote disposal site, the Burro Canyon site, was selected for the disposal of the Slick Rock UMTRA Project site tailings and contaminated materials. The Burro Canyon disposal site does not have the capacity to accept both the Slick Rock and Naturita contaminated materials. In addition, a review of the cost of codisposal of the Naturita RRM at the Burro Canyon site indicated that this alternative was more costly than disposal of the Naturita RRM at either the Dry Flats disposal site or a privately owned, non-DOE disposal facility. Based on these evaluations, codisposal of the 
Naturita and Slick Rock contaminated materials in the Slick Rock area was not considered further.

\section{Second comparative analysis of disposal site alternatives}

After the first comparative analysis, a formal, three-phase alternate site selection process (ASSP) (DOE, 1988b) was initiated to identify more viable disposal sites for the Naturita RRM. This process resulted in the selection of the Third Park, Dry Flats, and Bitter Basin alternate disposal sites. The Third Park site is approximately $15 \mathrm{road} \mathrm{mi}(24 \mathrm{~km})$ northeast of the Naturita site, and the Dry Flats site is approximately 6 road $\mathrm{mi}(10 \mathrm{~km})$ southeast of the processing site. The Bitter Basin site is approximately $9 \mathrm{road} \mathrm{mi}(14 \mathrm{~km})$ northwest of the Naturita site. The ASSP gave the Dry Flats site the highest ranking, followed by the Bitter Basin and Third Park sites. The Third Park site was dropped from further consideration because local residents and county officials expressed strong opposition to using this site.

After the ASSP was completed, a second comparative analysis of disposal site alternatives was performed (DOE, 1988a). It evaluated relocation of the Naturita RRM to the Coke Oven, Dry Flats, and Bitter Basin disposal sites. The Coke Oven alternative was retained from the first comparative analysis for comparative purposes because the Third Park alternate disposal site had been eliminated during the ASSP. The second comparative analysis also evaluated another conceptual design for disposal of the RRM at the Naturita processing site.

The additional conceptual design for disposal at the Naturita processing site was found to be the least expensive and quickest disposal alternative, but it was again the least favorable alternative in terms of technical and environmental factors and risks. As in the first comparative analysis, disposal at the Naturita site was not considered to be a viable remedial action alternative. The conceptual designs for disposal at the Coke Oven, Dry Flats, and Bitter Basin sites were similar to the conceptual design for disposal at the Naturita site, except that all of the RRM would be relocated from the processing site to a more remote disposal site. At each disposal site, the RRM would be stabilized in a disposal cell that would be designed for long-term stability and radiation protection in accordance with the EPA standards. The Coke Oven alternative would be the cheapest of the three relocation alternatives, but the Dry Flats alternative would be the most favorable of the relocation alternatives in terms of technical and environmental factors and risks. The Bitter Basin alternative would not be technically and environmentally suitable and would be the most expensive of the three relocation alternatives. Based on the two comparative analyses of disposal site alternatives, the DOE selected disposal at the Dry Flats site as a remedial action alternative for the Naturita RRM. The state of Colorado concurred in this selection. Based on the draft and final CADSARs for the Naturita site, the NRC has determined that the EPA standards could be satisfied at the Dry Flats disposal site. 



\subsection{PROPOSED ACTION}

\subsection{DESCRIPTION OF THE PROPOSED ACTION}

The proposed action is to relocate the RRM from the Naturita site to the currently licensed Title II site at Uravan or, in the case the Uravan site is determined to be unimplementable, to the alternate disposal site at Dry Flats. The RRM would consist of $243,200 \mathrm{yd}^{3}\left(186,000 \mathrm{~m}^{3}\right)$ of contaminated materials from the former tailings area, mill yard, and former ore storage area; $177,900 \mathrm{yd}^{3}\left(136,000 \mathrm{~m}^{3}\right)$ of contaminated materials from areas adjacent to the designated site; $8000 \mathrm{yd}^{3}\left(6100 \mathrm{~m}^{3}\right)$ of contaminated debris (e.g., buildings and foundations); and $400 \mathrm{yd}^{3}\left(310 \mathrm{~m}^{3}\right)$ of contaminated materials from vicinity properties. The total estimated volume of RRM to be relocated to the disposal site would be $429,500 \mathrm{yd}^{3}\left(328,400 \mathrm{~m}^{3}\right)$. Approximately $112,900 \mathrm{yd}^{3}$ $\left(86,300 \mathrm{~m}^{3}\right)$ of contaminated materials adjacent to the processing site and west of Colorado State Highway 141 would not be cleaned up with the application of supplemental standards, as discussed later in this section (also see Sections $4.5,5.1,5.4$, and 5.9).

Approximately 6 ac ( 2 ha) of the former ore storage area [12 ac (5 ha)] and the contamination west of Colorado State Highway 141 [112 ac (45 ha)] are on lands administered by the BLM. The rest of the contamination on and adjacent to the designated processing site is on privately owned lands. The cleanup of contamination on BLM-administered lands would be authorized by a memorandum of understanding (MOU) or other agreement between the BLM and DOE. The cleanup of contamination on privately owned lands would be authorized by remedial action agreements between individual land owners and the DOE.

After the remedial action, the Naturita processing site would be backfilled with clean fill material, recontoured to promote surface drainage, and revegetated. The site would then be released for development or other productive uses. The cleanup and/or control of existing ground water contamination beneath the processing site will be evaluated during the ground water restoration phase of the UMTRA Project.

Approximately 112 ac (45 ha) of steeply sloped, BLM-administered land adjacent to the Naturita processing site and west of Colorado State Highway 141 contain $112,900 \mathrm{yd}^{3}\left(86,300 \mathrm{~m}^{3}\right)$ of contaminated materials exceeding the EPA's surface cleanup standards. The cleanup of this contamination would have adverse environmental consequences and would be costly and potentially hazardous to remedial action workers. An application for implementing supplemental standards for this contamination would be submitted to the NRC and the state of Colorado. If this application were approved, this area would not be included in the remedial action. Other areas at and adjacent to the processing site may be considered for supplemental standards. If supplemental standards were implemented for additional areas, these areas would also not be 
cleaned up. Supplemental standards are discussed further in Sections 4.5, 5.1, 5.4 , and 5.9 .

Background levels of total suspended particulates (TSP), radionuclides, and noise would be established prior to any surface-disturbing activities associated with the remedial action. Monitoring programs would be developed and implemented by the Remedial Action Contractor (RAC) to ensure compliance with applicable standards or regulations. All remedial action vehicles that leave contaminated areas and enter public roadways would be monitored for contamination and decontaminated if necessary.

The proposed action includes the incorporation of the contaminated materials recovered from 21 vicinity properties associated with the Naturita processing site. The impacts associated with the vicinity property cleanup were evaluated in a separate document (DOE, 1985) and are not discussed further in this EA.

\subsubsection{Uravan disposal alternative}

The RRM would be moved from the Naturita processing site to the Uravan disposal site at Uravan, Colorado, where the RRM would be stabilized. The DOE would be responsible for transporting the Naturita RRM from the processing site to the Uravan site and for completing the remedial action at the processing site in accordance with the EPA standards for inactive (Title I) uranium processing sites (40 CFR Part 192, Subparts A, B, and C). A remedial action plan for the processing site would be prepared by the DOE for approval by the NRC and the state of Colorado.

Disposal at the Uravan site would be consistent with the EPA standards for active (Title II) uranium processing sites (40 CFR Part 192) and other appropriate authorizations and would be performed in accordance with a disposal plan prepared by the owner and operator of the site and approved by the CDPHE. At the Uravan site, the trucks hauling the Naturita RRM would be directed to the disposal area within the site and unloaded. The haulage trucks would then be decontaminated at a location within the Uravan site before returning to the Naturita processing site. The owner and operator of the Uravan site would be responsible for completing the Naturita RRM disposal area in accordance with the approved disposal plan. The selection of the Uravan disposal alternative would be predicated on the ability of the owner and operator of the Uravan site to provide a decontamination area within the site for the haulage trucks, the ability to begin receiving the Naturita RRM in March 1995 , and the ability to reach a fair and reasonable price for the disposal of the Naturita RRM. Selection of this alternative would also depend on the ability of the owner and operator of the Uravan site to provide an acceptable degree of indemnification for the DOE and state of Colorado and the ability to segregate, as much as possible, the Naturita RRM (Title I) from the Title II uranium mill tailings and other contaminated materials currently located at the site.

The Uravan disposal alternative would take approximately 24 months with two winter shutdown periods of 4 months each (December through March). The 
first 4 months of remedial action would consist of demolishing the structures at the Naturita processing site and preparing the necessary work areas and facilities. After the winter shutdown, the RRM would be relocated to the Uravan site for 8 months. The second winter shutdown would be followed by the final 4 months of remedial action, during which relocation of the RRM would be completed and the processing site would be restored. The Uravan disposal alternative would require less time than the Dry Flats disposal alternative because it would not be necessary to prepare the Dry Flats disposal site and the road to the disposal site.

\subsubsection{Dry Flats disposal alternative}

Construction of the Dry Flats disposal site would require a temporary withdrawal of approximately 105 ac (42 ha) of land, which would consist of the final disposal site [57 ac (23 ha)] and a 48-ac (19-ha) area around the final disposal site. The 48-ac (19-ha) temporary area would be used for a staging area (e.g., equipment washing and fuel storage facilities) and a stockpile area for uncontaminated earthen and rock materials. The DOE has obtained a 2-year segregation or temporary land withdrawal for the temporary Dry Flats disposal site from the BLM. Prior to any activity at this disposal site, a permanent jurisdiction transfer or permanent land withdrawal would be obtained from the BLM to transfer administration of the final disposal site to the DOE. The DOE would also obtain an ROW for the 48-ac (19-ha) temporary area around the final disposal site from the BLM. After the remedial action, the temporary area would be reclaimed in accordance with the ROW.

At the Dry Flats disposal site, the Naturita RRM would be placed in a disposal cell that would be excavated approximately $3 \mathrm{ft}(0.9 \mathrm{~m})$ below the ground surface (Figures 3.1 and 3.2). The debris from the processing site would be placed in the bottom of the disposal cell, then covered with the most highly contaminated materials followed by less-contaminated materials. All of the RRM would then be covered with a $1.5-\mathrm{ft}(0.5-\mathrm{m})$ thick layer of fine-grained earthen materials (radon barrier) to prevent radon emanation. Successive cover layers would consist of a $3-\mathrm{ft}(0.9-\mathrm{m})$ thick frost protection layer, a $0.5-\mathrm{ft}$ $(0.2-\mathrm{m})$ thick sand and gravel bedding layer, and a $1-\mathrm{ft}(0.3-\mathrm{m})$ thick layer of riprap. The disposal cell would cover approximately 21 ac $(9 \mathrm{ha})$. The final restricted disposal site would encompass 57 ac (23 ha), and the perimeter of the final disposal site would be fenced with a five-strand barbed wire fence $4.5 \mathrm{ft}(1.4 \mathrm{~m})$ high and signed with a warning specifying restricted access. A detailed description of the engineering design for the final Dry Flats disposal site will be provided in the remedial action plan (DOE, 1993a).

The Dry Flats disposal alternative would take approximately 36 months with three winter shutdown periods of 4 months each (December through March). The first 4 months of remedial action would consist of preparing the necessary work areas and facilities and demolishing the structures and other debris at the processing site. After the first winter shutdown, the disposal site and necessary roads would be prepared, and the relocation of the RRM would begin. The second winter shutdown would be followed by the relocation of the 


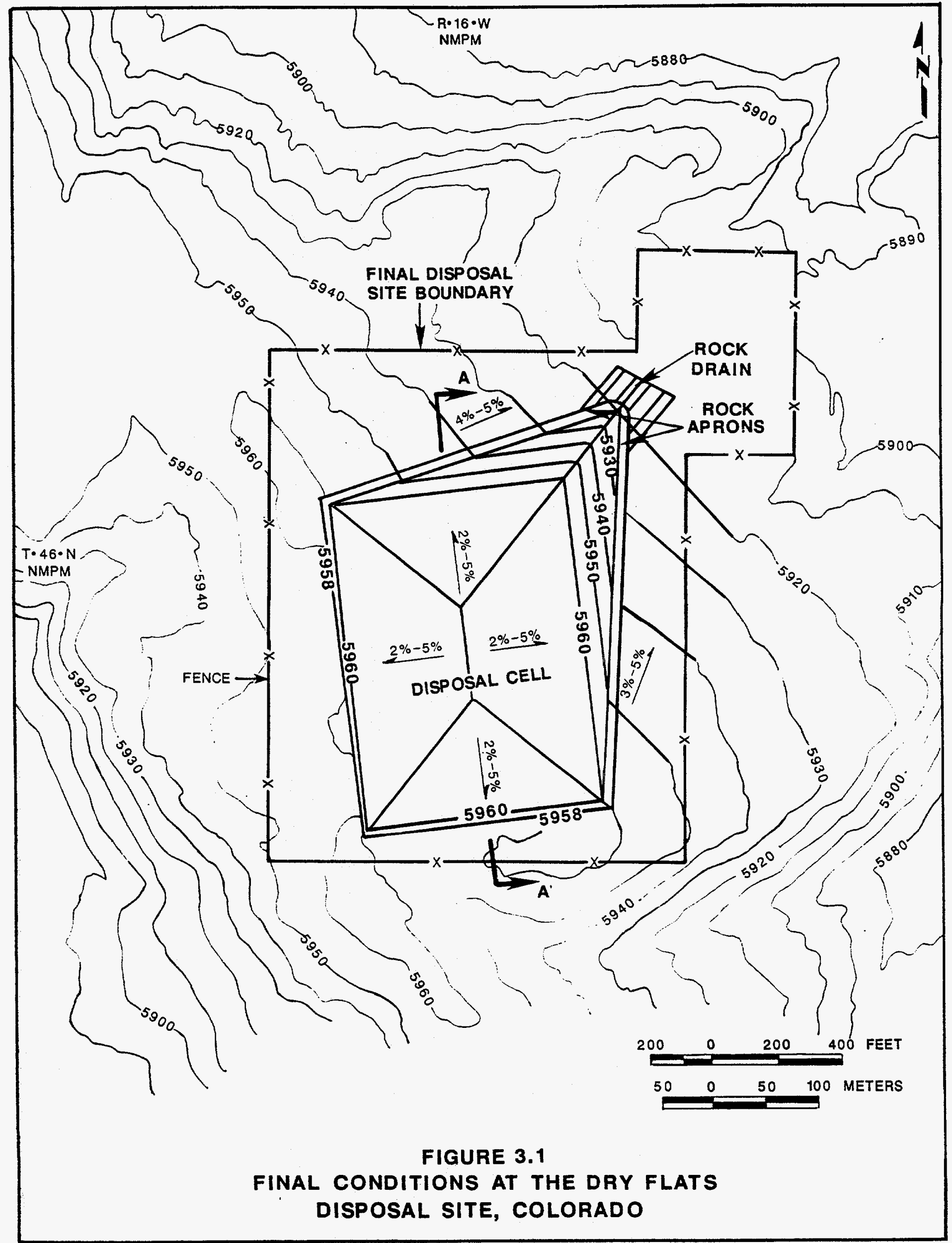




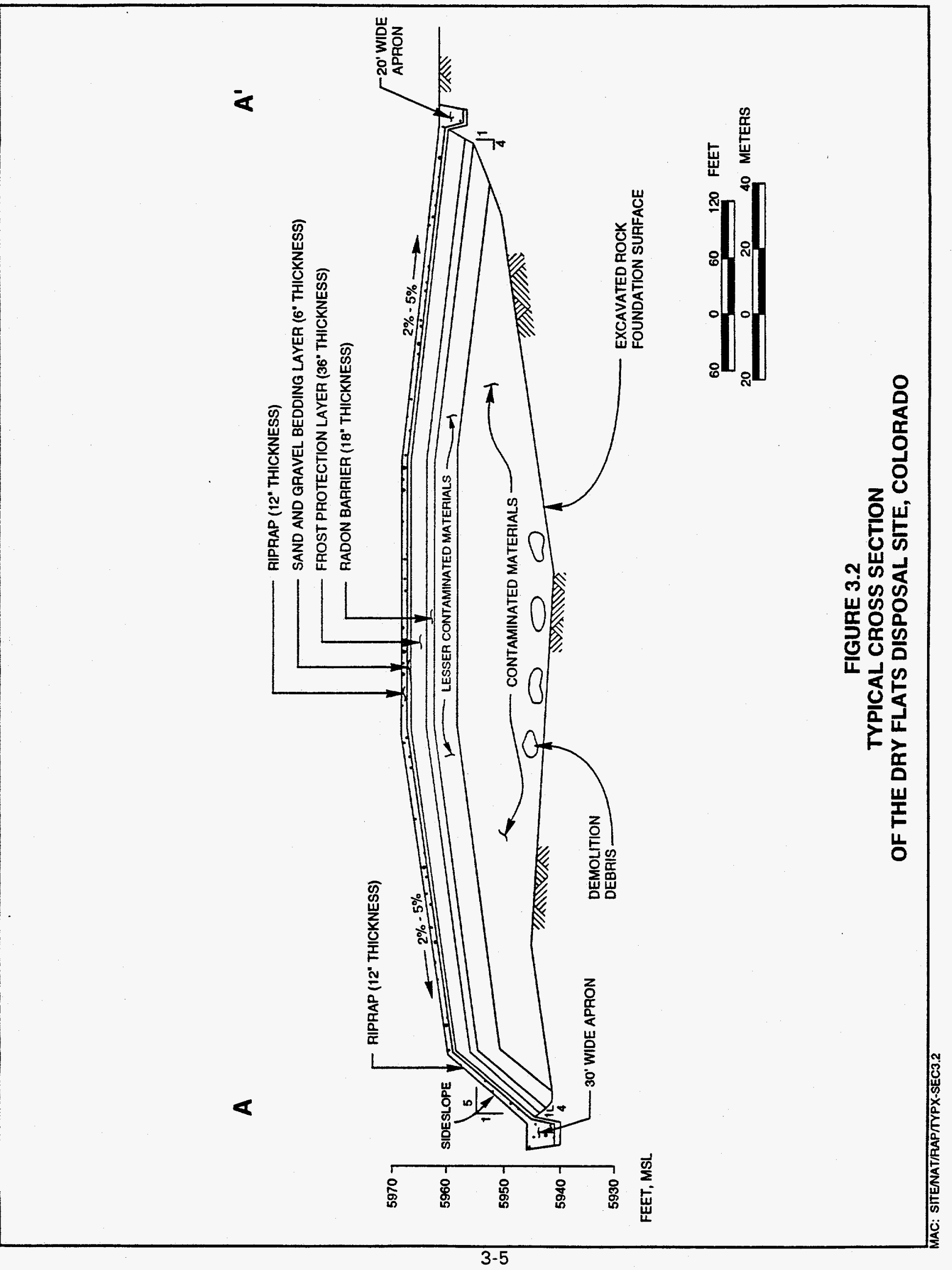


remaining RRM and the completion of the final disposal site. The final 4 months of remedial action would follow the third winter shutdown and would consist of the restoration of all disturbed areas. It is estimated that the remedial action would require from 13 to 76 workers, with an average work force of 54 workers. The estimated cost of the Dry Flats disposal alternative is $\$ 9.8$ million.

A detailed, site-specific, long-term surveillance program for the final Dry Flats disposal site would be developed jointly by the DOE and NRC to ensure the disposal site's continued compliance with the EPA standards. This program may include site inspections, aerial photography, ground water monitoring, surveillance reports, custodial maintenance, and contingency plans in case of severe natural events or unusual human intrusion.

\section{$3.2 \quad$ BORROW SITES}

\subsubsection{Uravan disposal alternative}

Approximately $236,800 \mathrm{yd}^{3}\left(181,100 \mathrm{~m}^{3}\right)$ of earthen materials would be required for the restoration of the Naturita processing site after completion of the Uravan disposal alternative. It is anticipated that these earthen materials would be obtained from existing, privately owned, commercial borrow sites in the vicinity of the processing site. This would preclude the use of the Coke Oven borrow site. Gravel and rock would not be required for the remedial action because the road to the Coke Oven borrow site and Dry Flats disposal site would not be prepared and the Dry Flats disposal cell would not be constructed.

It is possible that the earthen materials for the restoration of the Naturita processing site would be obtained from the Coke Oven borrow site. The use of the Coke Oven borrow site would require a Free Use Permit issued by the BLM and a Mined Land Reclamation Permit from the Colorado Division of Minerals and Geology; the operation and restoration of the borrow site would be performed in accordance with these permits. If the Coke Oven borrow site were used, approximately $1 \mathrm{mi}(2 \mathrm{~km})$ of County Road GG-25 from Colorado State Highway 90 to the borrow site would be improved. This would require approximately $6000 \mathrm{yd}^{3}\left(4600 \mathrm{~m}^{3}\right)$ of gravel, which would be obtained from existing, commercial quarry sites (described in Section 3.2.2).

\subsubsection{Dry Flats disposal alternative}

The Dry Flats disposal alternative would require the use of earthen materials, gravel, and rock. Earthen materials for restoration of the Naturita processing site would be excavated from the Coke Oven borrow site (Figure 2.41. Earthen materials would also be excavated from this borrow site for construction of the Dry Flats disposal cell and for restoration of the final Dry Flats disposal site. Some of the earthen materials for restoration of the processing site would also be obtained from the excavation of the Dry Flats disposal cell. The Coke Oven borrow site is in Sec. 35, T46N, R16W, NMPM, approximately 5 road mi $(8 \mathrm{~km})$ 
south of the processing site and 1 road mi $(2 \mathrm{~km})$ west of the Dry Flats disposal site. The borrow site is on BLM-administered land that is used for livestock grazing, and the proposed use of the borrow site would have to be authorized by a Free Use Permit issued by the BLM. As part of this authorization, no surface disturbance could occur at the borrow site until a mining and reclamation plan was approved by the BLM. In addition, a Mined Land Reclamation Permit would have to be obtained from the state of Colorado's Division of Minerals and Geology prior to any surface disturbance.

The Coke Oven borrow site would cover a maximum area of 175 ac ( 71 ha). Of this area, 40 ac (16 ha) contain cultural resource sites (Section 4.8) and would not be disturbed by the borrow activities. A maximum of 80 ac ( 32 ha) would be disturbed by the excavation of approximately $431,100 \mathrm{yd}^{3}\left(329,600 \mathrm{~m}^{3}\right)$ of earthen materials, and a maximum of 55 ac ( 22 ha) would be used for material stockpiling, equipment parking, and other purposes. Surface soil at the borrow site would be removed and stockpiled for restoration of the site. The earthen materials for the remedial action would be excavated to depths ranging from 4 to $10 \mathrm{ft}(1$ to $3 \mathrm{~m})$. After completion of the remedial action, the borrow site would be recontoured to resemble the surrounding land surface and to promote surface drainage. All disturbed areas would then be revegetated according to the approved mining and reclamation plan.

The proposed sources of gravel and rock for the construction of access roads and the Dry Flats disposal cell are existing, privately owned, commercial quarry sites 22 road mi $(35 \mathrm{~km})$ northwest of the Naturita processing site.

Approximately $86,600 \mathrm{yd}^{3}\left(66,200 \mathrm{~m}^{3}\right)$ of gravel and rock would be required.

\subsection{TRANSPORTATION ROUTES}

\subsubsection{Uravan disposal alternative}

The Naturita RRM would be transported by truck from the former processing site to the Uravan disposal site along Colorado State Highway 141. All of the Naturita RRM would be transported in accordance with applicable U.S.

Department of Transportation (DOT) and Colorado Department of Transportation (CDOT) regulations and any MOUs or other agreements between the DOE, DOT. CDOT, and the owner and operator of the Uravan site.

The use of Colorado State Highway 141 to transport the Naturita RRM would involve crossing a bridge over the San Miguel River from Colorado State Highway 141 to the Uravan site. Should this bridge not have sufficient weight capacity for haulage trucks loaded with RRM, the bridge would be improved to provide the necessary weight capacity. It is possible that the haul trucks could use County Road EE-22, a dirt road that intersects Colorado Highway 141 approximately $11 \mathrm{mi}(18 \mathrm{~km})$ northeast of the processing site; however, some improvements and more frequent maintenance would be required. In the latter case, the RRM would be transported on Colorado State Highway 141 for approximately $11 \mathrm{road} \mathrm{mi}(18 \mathrm{~km})$, then approximately 2 road $\mathrm{mi}(3 \mathrm{~km})$ via the 
county road to the Uravan site. Any improvement of County Road EE-22 would be coordinated with the Montrose County Road Commission, the owners of lands crossed by the county road (e.g., BLM), and the owner and operator of the Uravan site. It is anticipated that widening County Road EE-22 would not be necessary because empty haulage trucks could use the bridge over the San Miguel River and Colorado State Highway 141 to return from the Uravan site to the processing site. This would avoid two-way haulage truck traffic on the narrow county road.

After completion of the remedial action, earthen materials would be transported to the Naturita processing site for restoration of the site. It is anticipated that these earthen materials would be obtained from existing, privately owned, commercial borrow sites in the vicinity of the processing site. In this case, the majority of the transportation of the earthen materials would take place on Colorado State Highways 90,141 , and $90 / 141$ and county roads. If the Coke Oven borrow site were used to provide the earthen materials, the materials would be transported by truck from the borrow site to the processing site on Colorado State Highways 90 and 141 and County Road GG-25. Gravel for the improvement of County Road GG-25 would be transported by truck from existing, commercial quarry sites to the Coke Oven borrow site along Colorado State Highways 141 and 90 , County Road GG-25, and possibly other county roads. All of the borrow materials would be transported in accordance with applicable DOT and CDOT regulations and any MOUs or other agreements between the DOE, DOT, CDOT, and the owners and operators of any selected commercial borrow sites.

If the Coke Oven borrow site were used to provide earthen materials for the restoration of the Naturita processing site, approximately $1 \mathrm{mi}(2 \mathrm{~km})$ of County Road GG-25 from Colorado State Highway 90 to the borrow site would be improved as described below for the Dry Flats disposal alternative. The improved county road would cover approximately 4 ac ( $2 \mathrm{ha}$ ). A ROW $100 \mathrm{ft}$ $(30 \mathrm{~m})$ wide for the road improvement would be obtained from the BLM by the Montrose County Road Commission and would cover approximately 12 ac (5 ha). If the improved county road crossed any private lands, the DOE would negotiate land-use agreements for the road improvement with the land owners. After completion of the remedial action, the improved County Road GG-25 would be left intact except that the culvert crossing would be removed and replaced with another concrete, low water crossing as requested by the Montrose County Road Commission.

It is unlikely that temporary utilities would be extended to the Coke Oven borrow site. However, if temporary utilities were extended to the borrow site, the installation and removal of the utilities would be performed as described below for the Dry Flats disposal alternative. The installation and removal of the utilities and the reclamation of any associated land disturbance would be subject to an appropriate ROW issued by the BLM and to land-use agreements negotiated with the land owners of any private lands crossed by the improved County Road GG-25. It is estimated that the ROW for the utilities [30 $\mathrm{ft}(9 \mathrm{~m})$ wide and $1 \mathrm{mi}(2 \mathrm{~km})$ long] would cover approximately $4 \mathrm{ac}(2 \mathrm{ha})$. 


\subsubsection{Dry Flats disposal alternative}

The Naturita RRM would be transported by truck from the processing site to the Dry Flats disposal site along Colorado State Highways 141 and 90, County Road GG-25, and a new haul road from County Road GG-25 to the disposal site (Figure 2.4). The Coke Oven borrow site would be adjacent to County Road GG-25, and no haul road to the borrow site would be necessary. Gravel and rock would be trucked from existing, commercial quarry sites to the disposal site along Colorado State Highways 141 and 90, County Road GG-25, and the new haul road. All of the materials would be transported in accordance with applicable DOT and CDOT regulations and any MOUs or other agreements between the DOE, DOT, and CDOT.

County Road GG-25 is approximately $10 \mathrm{ft}(3 \mathrm{~m})$ wide and has a concrete, low-water crossing at Dry Creek. The county road now covers approximately $3 \mathrm{ac}(1 \mathrm{ha})$ over the $2.5 \mathrm{mi}(4 \mathrm{~km})$ to the Dry Flats disposal site. The county road would be widened to a maximum of $32 \mathrm{ft}(10 \mathrm{~m})$ and improved, and a culvert crossing would be installed at Dry Creek. The improved county road would cover approximately 10 ac (4 ha). Approximately $0.25 \mathrm{mi}(0.4 \mathrm{~km})$ of new haul road would be constructed from County Road GG-25 to the disposal site. This haul road would be $32 \mathrm{ft}(10 \mathrm{~m})$ wide and would cover approximately 1 ac $(0.4$ ha).

County Road GG-25 crosses land administered by the BLM and a small tract of private land. The new haul road to the disposal site crosses only BLM-administered land. A ROW $100 \mathrm{ft}(30 \mathrm{~m})$ wide for the improvement of County Road GG-25 would be obtained from the BLM by the Montrose County Road Commission. This ROW would cover approximately 30 ac (12 ha). The DOE would negotiate a land-use agreement for the road improvement with the owner of the small tract of private land crossed by the county road. Another $100-\mathrm{ft}(30-\mathrm{m})$ wide ROW for the construction of the new haul road would be obtained from the BLM by the DOE; this ROW would cover approximately 3 ac (1 ha). After completion of the remedial action, the improved County Road GG-25 would be left intact except that the culvert crossing at Dry Creek would be removed and replaced with another concrete, low-water crossing. This action was requested by the Montrose County Road Commission. The new haul road would be reduced to minimum BLM standards [e.g., $16 \mathrm{ft}(5 \mathrm{~m})$ wide], and the excess road width [approximately 0.5 ac $(0.2 \mathrm{ha})]$ would be reclaimed in accordance with the ROW issued by the BLM.

If temporary utilities such as water and telephone service were extended to the Dry Flats disposal site, they would be placed immediately adjacent to improved County Road GG-25 and the new haul road. The utilities would be placed above or below the ground surface as required and would be removed upon completion of the remedial action. The appropriate ROW for these utilities would be obtained from the BLM, and this ROW would probably be $30 \mathrm{ft}(9 \mathrm{~m})$ wide and $2.75 \mathrm{mi}(4.4 \mathrm{~km}$ ) long [10 ac (4 ha)]. Any land disturbed by the installation and removal of the utilities would be reclaimed in accordance with the requirements 
of the ROW. The temporary utilities would also cross the small tract of private land along County Road GG-25. The installation and removal of the utilities and reclamation of any land disturbance on this private land would be performed in accordance with the land use agreement negotiated with the owner for the county road improvements.

\subsection{CONFORMANCE TO LAND USE PLANS AND POLICIES}

Areas at and adjacent to the Naturita processing site, the Dry Flats disposal site, and the Coke Oven borrow site are on lands administered by the BLM's Uncompahgre Basin Resource Area. These lands are subject to the BLM resource management plan as well as the applicable BLM permits. For the Uncompahgre Basin Resource Area, the emphasized resources are wildlife, grazing, minerals, cultural resources, and recreation (BLM, 1985; Pfifer, 1993). The BLM's administration of the lands to be affected by the remedial action and the authorization of the applicable permits would reflect the resources emphasized in the resource management plan.

Montrose County does not have a land use master plan for the west end of the county, which includes the Naturita area. The Naturita area is zoned for general agriculture, and there are no restrictions on any development that is not restricted in other areas as long as all applicable permits are obtained. There are no land use or zoning restrictions that would prohibit the proposed remedial action for the Naturita processing site (Warren, 1993). There is a local desire to develop the processing site as a golf course (Showalter, 1993). The proposed remedial action would allow the processing site to be released for any use consistent with existing land use controls. However, certain use restrictions may be imposed at the federal and state levels to protect human health and the environment and to prevent the use of potentially contaminated ground water at the site. Certain use restrictions may also be imposed at the federal and state levels to allow future cleanup and/or control of existing ground water contamination beneath the processing site during the ground water restoration phase of the UMTRA Project.

If the Naturita RRM were removed to the existing Uravan disposal site, the owner and operator of the Uravan site would be responsible for complying with the applicable land use plans, policies, and regulations.

\subsection{COMPLIANCE WITH EPA STANDARDS}

The purpose of the proposed remedial action is to stabilize and control all contaminated materials associated with the Naturita processing site in a manner that complies with the EPA standards in 40 CFR Part 192. As stated in Section 2.1, the EPA standards for active (Title II) uranium processing sites are also contained in 40 CFR Part 192. These standards are essentially the same as those for inactive sites. Whether the Uravan site is selected for the disposal of the Naturita RRM or not, the owner and operator of the Uravan site would be responsible for complying with all Title II regulations, including the appropriate 
EPA standards. The disposal of Naturita RRM at the Uravan site would be performed pursuant to a disposal plan approved by the CDPHE/RCD. The DOE would still be responsible for completing the remedial action at the Naturita processing site in accordance with the EPA standards for inactive uranium processing sites.

Consistent with this purpose and the EPA standards, the following major design objectives were established for the Dry Flats disposal alternative:

- Levels of radium-226 (Ra-226) would be reduced to levels consistent with the EPA standards in areas released for unrestricted use. The concentration of Ra-226 in soil averaged over any area of 100 square meters $\left(\mathrm{m}^{2}\right)$ would not exceed the background level by more than 5 picocuries per gram $(\mathrm{pCi} / \mathrm{g})$ averaged over the first 15 centimeters $(\mathrm{cm})$ of soil below the surface, and $15 \mathrm{pCi} / \mathrm{g}$ averaged over $15 \mathrm{-cm}$-thick layers of soil more than $15 \mathrm{~cm}$ below the surface. If residual radionuclides other than $\mathrm{Ra}-226$ and its decay products are present in sufficient quantities and concentrations to pose a significant radiation hazard, supplemental standards would be developed and applied with NRC concurrence. Remedial action would reduce other residual radioactivity to levels that are as low as reasonably achievable.

- The engineering design controls would be effective for up to 1000 years to the extent reasonably achievable and, in any case, for at least 200 years.

In addition, the design for the Dry Flats disposal site must comply with the proposed EPA ground water protection standards for inactive uranium mill sites, in Subparts A and C of 40 CFR Part 192 (52 FR 36000; September 24, 1987). The DOE has designed a multicomponent cover system that would meet the radiation protection standard, reduce the amount of infiltration from precipitation, and protect the radon barrier from frost and biointrusion. The cover system for the Dry Flats disposal site would achieve compliance with the proposed EPA standards.

When final ground water protection standards are promulgated, the DOE would evaluate ground water protection requirements and would undertake any action necessary to ensure that the final standards are met. The need for and extent of ground water remediation at the Naturita processing site will be evaluated during the ground water restoration phase of the UMTRA Project. 


\subsection{AFFECTED ENVIRONMENT}

The existing environmental conditions at the Naturita processing site, Dry Flats disposal site, and Coke Oven borrow site are described in this section. The Uravan disposal site at Uravan, Colorado, is approximately 13 road mi $(21 \mathrm{~km})$ northwest of the Naturita processing site. The existing environmental conditions at the Uravan site would be expected to be very similar to those described for the Naturita processing site.

\subsection{CLIMATE AND AIR QUALITY}

The Naturita region has a semiarid continental climate with low precipitation and humidity, large temperature variations, and high evaporation. The annual mean maximum temperature is 65 degrees Fahrenheit $\left({ }^{\circ} \mathrm{F}\right)\left[18\right.$ degrees Celsius $\left.\left({ }^{\circ} \mathrm{C}\right)\right]$, and the annual mean minimum temperature is $36^{\circ} \mathrm{F}\left(2^{\circ} \mathrm{C}\right)$. The annual mean precipitation is probably between 9 and 16.5 inches (in) $(23$ and $42 \mathrm{~cm}$ ), with most precipitation occurring from July through October. The average annual snowfall is expected to be 30 to 32 in $(76$ to $81 \mathrm{~cm}$ ) (NOAA, 1986, 1984). The topography at the Naturita site indicates that north-northwest, down-valley and south-southwest, up-valley winds would prevail at the processing site. The estimated average annual wind speed at the Dry Flats disposal site is expected to be 7 miles per hour (mph) [6 knots ( $k t)]$ (Pioneer, 1979), and the average wind speed at the Naturita site would be expected to be somewhat less given the protected nature of the San Miguel River Valley.

Weather observations at the Uravan site have been performed by the site owner and operator since August 1972. Data records include daily maximum and minimum temperatures, daily precipitation, and continuous records of wind direction and wind speed. The annual mean maximum temperature was $68^{\circ} \mathrm{F}$ $\left(20^{\circ} \mathrm{C}\right)$, and the annual mean minimum was $36^{\circ} \mathrm{F}\left(2^{\circ} \mathrm{C}\right)$. The annual average total precipitation received at the Uravan site from 1973 through 1977 was 10.1 in $(25.6 \mathrm{~cm})$. Winds at the Uravan site are strongly influenced by the San Miguel River Valley. The highest frequency wind directions generally parallel the river valley and are from the southeast and northwest. These winds represent the drainage flow of air that occurs generally during the night and early morning hours. The annual mean wind speed is approximately $4 \mathrm{mph}$ (3 kt) (State of Colorado, 1983).

The closest Colorado air quality monitoring station is in Montrose. Only TSP are monitored at this station (CDPHE, 1985). In addition, 9 months of ambient TSP data are available for Disappointment Valley, approximately 15 air mi $(24 \mathrm{~km})$ southwest of the Naturita site. The Disappointment Valley data reveal no violations of federal (40 CFR Part 50) and state (CAOCC, 1979) primary and secondary standards for TSP (Pioneer, 1979). None of the remaining EPA priority air pollutants (sulfur dioxide, carbon monoxide, ozone, nitrogen dioxide, and lead) are measured at or near Naturita. However, the levels of these pollutants are expected to be very low due to the remote nature of the site. The Naturita area is considered to be in attainment for TSP and the other EPA priority air pollutants. 


\subsection{GEOLOGY AND SOILS}

The Naturita site is underlain by unconsolidated alluvial floodplain deposits of the San Miguel River and fill material. The fill material was placed during construction of the site to divert the river and increase the area of the existing alluvial terrace. The alluvium consists of rounded river gravel and cobbles in a silty to clayey-sand matrix and is underlain by the Brushy Basin and Salt Wash Members of the Jurassic Morrison Formation. The Brushy Basin Member consists of interbedded shale, sandstone, and conglomerate lenses; the Salt Wash Member is composed of sandstones with some shales.

Uravan is in the eastern part of the Canyonland section of the Colorado Plateau physiographic province. The topography of this region is primarily canyons and mesas. Resistant sandstone units that cap the mesas in the area are the Dakota and Burro Canyon Formations and the Salt Wash Member of the Morrison Formation. Principal streams in the immediate area of Uravan have formed the mesa and canyon topography and include the San Miguel River, Spring Creek, Atkinson Creek, and Tebeguache Creek.

Approximately $18,400 \mathrm{ft}(5610 \mathrm{~m})$ of relatively flat-lying Paleozoic and Mesozoic-age sedimentary rock underlie the Uravan area. This sedimentary section consists of about $1700 \mathrm{ft}(520 \mathrm{~m})$ of Mesozoic rock that consists primarily of sandstone, mudstone, and shale of continental origins. The Mesozoic rocks are underlain by approximately $16,700 \mathrm{ft}(5090 \mathrm{~m})$ of Paleozoic rocks consisting of non-marine sandstones and marine carbonates, evaporites, and shales. This thick sedimentary section rests on Precambrian-age crystalline rocks. Surficial deposits are usually thin and are primarily colluvial, residual, and eolian deposits interspersed with bedrock outcrops along the canyon sides and on the mesa tops.

Uravan is located on the southwest limb of the northwest-trending Nucla syncline. This syncline is a relatively simple structure downwarp that lies between the structurally more complex Uncomphagre Uplift and the Paradox Valley anticline. Club Mesa is directly southwest of Uravan and is approximately $400 \mathrm{ft}(122 \mathrm{~m})$ above the San Miguel River. Bedrock units in the area are, from youngest to oldest, the Brushy Basin and Salt Wash Members of the Morrison Formation, Summerville, Entrada/Carmel, Navajo, and Kayenta Formations.

Most of these formations are dominated by thick sandstone sequences. Two of these units are predominantly shale units: the Brushy Basin Member and the Summerville Formation. Surface materials are very thin on Club Mesa, generally less than $10 \mathrm{ft}(3 \mathrm{~m})$ thick and are composed of residuum, colluvium, and alluvium.

The existing tailings piles are likely underlain by a thin veneer of surficial materials that is less than $10 \mathrm{ft}(3 \mathrm{~m})$ thick and sandstone bedrock. This bedrock is the Salt Wash Member; it is about $100 \mathrm{ft}(30 \mathrm{~m})$ thick and is 
composed of thick sandstone with interstratified lenses of claystone and siltstone. Beneath the Salt Wash is the shaley Summerville Formation and sandstones of the Entrada/Carmel, Navajo, and Kayenta Formations. The sandstone units beneath the tailings piles have both primary and secondary permeability.

The alternate Dry Flats disposal site is on a broad mesa that dips gently to the northeast. Soils at the disposal site consist mostly of silty clay that is underlain by claystone-shale along the crest of the site and by sandstone over the rest of the area. These are the uppermost strata of the Cretaceous Dakota Sandstone. Resistant sandstone is exposed on drainage divides and in drainages in about 20 percent of the site area. A broad joint pattern with three sets of trends influences the drainage and erosional patterns. The local drainages become increasingly more incised downslope as they approach the canyon of the San Miguel River. Over most of the site, sandstone lies within $2 \mathrm{ft}(0.6 \mathrm{~m})$ of the surface and apparently represents a previously exposed surface. Some of the lower slopes at the disposal site range from 3 to 4 percent, and the soil cover has been eroded to expose resistant sandstone in the flat-bottomed drainages. There are no significant incisions in the channels, and gullying has not developed on any sandstone surfaces.

Mineral resources in the region with potential economic value are uranium, potash, coal, and oil and gas. Uranium does not occur in the area of the Dry Flats disposal site. The nearest uranium deposits are within the Colorado Uranium Belt several miles to the west. Potash has been associated with the Paradox Valley salt core structure adjacent to the Dry Flats site, but the only known potash production has been near Moab, Utah, more than $40 \mathrm{mi}(64 \mathrm{~km})$ to the west. Coal seams occur within the Dakota Sandstone at the Dry Flats site, but only a few of the boreholes drilled at the site encountered coal. These shaley and discontinuous coal seams were less than $2 \mathrm{ft}(0.6 \mathrm{~m})$ thick and up to $20 \mathrm{ft}(6 \mathrm{~m})$ deep. Coal seams less than $3 \mathrm{ft}(1 \mathrm{~m})$ thick are generally not economical at that depth. The nearest coal mine is approximately $3 \mathrm{mi}(5 \mathrm{~km})$ east of the Dry Flats site.

Several natural gas deposits have been developed in the region, but oil production has been relatively minor. The production has been mostly from formations of Permian and Pennsylvanian age at depths on the order of $2200 \mathrm{ft}$ $(671 \mathrm{~m})$. Reports indicate that these formations have been intensely mapped by geophysical surveys for potential petroleum resources, but there has been no oil and gas development near the Dry Flats disposal site. The nearest active gas field is at Andy's Mesa, approximately $10 \mathrm{mi}(16 \mathrm{~km})$ south of the Dry Flats site. The Montrose Dome gas field was $3 \mathrm{mi}(5 \mathrm{~km})$ southwest of the Dry Flats site on the south side of Coke Oven Valley near Dry Creek. This field was last operated in 1958. The oil and gas leases on BLM-administered lands near the Coke Oven borrow site are adjacent to the Montrose Dome gas field.

The site region lies entirely within the Colorado Plateau Interior seismotectonic province. Most of the recorded earthquakes that affect the Colorado Plateau in 
this province are at the boundary of the plateau. Within a $40-\mathrm{mi}(64-\mathrm{km})$ radius of the Dry Flats disposal site, only one earthquake of magnitude 4.0 has been recorded (NGDC/NOAA, 1989).

\subsection{SURFACE WATER AND FLOOD HAZARD}

The Naturita processing site is on the west bank of the San Miguel River, which flows in a northwesterly direction through San Miguel Canyon. The San Miguel River originates in the San Juan Mountains near Telluride, Colorado, and joins the Dolores River $20 \mathrm{mi}(32 \mathrm{~km}$ ) downstream from the town of Naturita. In the vicinity of the processing site, the San Miguel River has a drainage area of 1209 square miles $\left(\mathrm{mi}^{2}\right)$ [3131 square kilometers $\left.\left(\mathrm{km}^{2}\right)\right]$.

A U.S. Geological Survey (USGS) gaging station on the San Miguel River near the town of Naturita is $3 \mathrm{mi}(5 \mathrm{~km}$ ) upstream of the processing site. The recorded average maximum and average mean monthly flows were 2000 and 330 cubic feet per second $\left(\mathrm{ft}^{3} / \mathrm{s}\right)\left[57\right.$ and 9 cubic meters per second $\left.\left(\mathrm{m}^{3} / \mathrm{s}\right)\right]$, respectively; however, on April 15, 1942, a peak flow of $7100 \mathrm{ft}^{3} / \mathrm{s}\left(201 \mathrm{~m}^{3} / \mathrm{s}\right)$ was recorded (USGS, 1979). Approximately 31 ac (13 ha) of the former tailings area and mill yard are within the 100-year floodplain of the San Miguel River (Attachment 1, Floodplains and Wetlands Assessment).

There are no current uses of the water in the San Miguel River in the vicinity of the processing site. The town of Naturita currently withdraws water from the San Miguel River upstream of the processing site for municipal use. Withdrawal of water downstream of the processing site is minimal (Trachsler, 1989).

Surface water quality for the San Miguel River depends on the flow rate of the river. The concentration of total dissolved solids (TDS) upstream from the Naturita site varies inversely with flow rate; the suspended sediment concentrations vary widely and are directly proportional to the flow rate. All trace metal concentrations reported from the river upstream from the processing site have been below the levels specified by the EPA in the National Interim Primary Drinking Water Regulations (40 CFR Part 141). There were substantial increases in dissolved Ra-226 concentrations in the river between sampling points upstream and downstream of the processing site before the tailings were removed (ORNL, 1980). Since the removal of the tailings in 1979, the DOE's sampling of the river water has not revealed any contamination attributable to the processing site.

The Uravan disposal site is on the west bank of the San Miguel River on a mesa approximately $400 \mathrm{ft}(122 \mathrm{~m})$ above the river valley. The San Miguel is the primary drainage in the area of the disposal site. Headwaters of the San Miguel originate in the San Juan Mountains; from there, the river flows northwest to its confluence with the Dolores River, approximately $4 \mathrm{mi}(6 \mathrm{~km})$ downstream from Uravan. Although the San Miguel River is perennial, its hydrograph exhibits pronounced seasonal fluctuations. This streamflow pattern is characteristic of rivers having flows derived primarily from snowmelt runoff. Peak discharges on 
the San Miguel generally occur in late spring or early summer. Three creeks join the San Miguel in the Uravan area: a small intermittent creek drains Hieroglyphic Canyon along the southeast edge of Club Mesa; Atkinson Creek borders Spring Creek Mesa on the northwest; and Spring Creek borders the southeast side of the mesa. The two latter creeks also flow intermittently.

Discharge in Hieroglyphic Canyon, Atkinson Creek, and Spring Creek is related to rainstorm runoff. Creek flows tend to be greatest during the spring and summer and lowest during winter and fall. During the low flow season, discharge from these creeks may be reduced to zero. Numerous unnamed small ephemeral channels drain to the San Miguel River from the mesas surrounding the canyon. Because of their relatively small drainage areas and the arid climate, these channels carry water only during rainstorm events.

The Dry Flats disposal site is approximately 1 air $\mathrm{mi}(2 \mathrm{~km})$ south of and $500 \mathrm{ft}$ $(152 \mathrm{~m})$ above the San Miguel River, which is the nearest perennial stream. A topographic drainage divide runs across the Dry Flats site from northwest to southeast, and the disposal cell would be located principally on the northeast side of the divide. Ephemeral surface water flow on the northeast side follows a number of drainages toward the San Miguel River. Ephemeral surface water flow on the southwest side follows drainages toward Dry Creek. Flooding is not considered to be a hazard at the Dry Flats disposal site because of the location near a drainage divide and the distance from, and elevation above, the closest perennial stream channel (the San Miguel River).

\subsection{GROUND WATER}

\subsubsection{Naturita processing site}

Ground water beneath the Naturita processing site occurs in unconsolidated alluvial floodplain deposits of the San Miguel River and in sandstones of the Salt Wash Member of the Jurassic Morrison Formation. The alluvium is considered to be the uppermost aquifer at the site. Ground water depths in the alluvium range from 2.5 to $18 \mathrm{ft}(0.8$ to $5 \mathrm{~m})$ below the land surface. The occurrence of shallow ground water in the alluvial aquifer is limited by the lateral extent of the alluvium in the vicinity of the site. The alluvial aquifer is recharged principally by seepage from the San Miguel River southeast of the site and by the infiltration of precipitation. The ground water flow direction in the alluvium is approximately parallel to the river. Ground water is discharged from the alluvial aquifer by seepage into the river northwest of the site where the river valley narrows.

In the Salt Wash Member, ground water is confined with a potentiometric surface that is higher in elevation than the water table in the alluvium. The alluvium and the Salt Wash Member are separated by a regional aquitard (Brushy Basin Member of the Jurassic Morrison Formation) consisting of thick, laterally extensive, interbedded shales with some sandstones. There is no observed hydraulic interconnection between the alluvium and the Salt Wash Member in 
the vicinity of the site. The Salt Wash Member is a major regional ground water system in the Naturita area. The recharge area for the Salt Wash aquifer consists of the upturned edge of this formation on the southwestern flank of the Uncompahgre Uplift. The potential area of natural discharge from the Salt Wash aquifer is the San Miguel River northwest of the Naturita site before reaching Uravan, Colorado.

Background ground water quality is defined as the quality of ground water at the site if contamination had not occurred from uranium processing activities. In the alluvial aquifer, the ground water has $\mathrm{pH}$ values that range from 6.7 to 7.3, and the ground water is characterized as a mixed cation (sodiumpotassium-magnesium-calcium/sulfate bicarbonate) type. The average TDS content is approximately 1100 milligrams per liter $(\mathrm{mg} / \mathrm{L})$. Analyses of ground water samples indicated that background concentrations of molybdenum, nitrate, selenium, and uranium have exceeded the proposed EPA maximum concentration limits $(\mathrm{MCL})$ at some time; all other hazardous constituent concentrations were below the proposed EPA MCLs. Nitrate exceeded the proposed EPA MCL only once and could have been the result of laboratory contamination or improper sampling. Also, uranium was slightly above the proposed $\mathrm{MCL}$ only once, and all other uranium concentrations were below the proposed $\mathrm{MCL}$.

Background ground water quality in the Salt Wash aquifer is affected by the presence of naturally occurring uranium mineralization underlying the Naturita site. Ground water in the Salt Wash Member has not been affected by uranium processing activities at the site due to the Brushy Basin Member aquitard separating the Salt Wash Member from the alluvium. The $\mathrm{pH}$ values range from 7.0 to 7.4 , and the ground water is characterized as a sodium-sulfate-chloride type. The average TDS concentration is $5684 \mathrm{mg} / \mathrm{L}$. Ground water analyses indicated that background concentrations of molybdenum, selenium, and uranium and activities of net gross alpha and Ra-226 and Ra-228 have exceeded the proposed EPA MCLs. All other hazardous constituents have been below the proposed EPA MCLs.

Ground water from several wells within $2 \mathrm{mi}(3 \mathrm{~km})$ of the Naturita processing site is used for domestic purposes. These wells are located in the San Miguel River valley upgradient of the processing site and adjacent to the valley north of the river. Ground water is drawn from the alluvial and Salt Wash aquifers. There is no potential for contamination of these wells, because the Salt Wash aquifer is not hydraulically interconnected with the alluvium and the river is a discharge point for the alluvial ground water. No future use of the alluvial aquifer is expected, because the alluvium has a finite lateral extent in the vicinity of the site and a limited ability to supply ground water. Alternative supplies of good quality water are available from the town of Naturita. Naturita's primary and secondary water supplies are the San Miguel River and a deep well in the Salt Wash aquifer, respectively. 


\subsubsection{Uravan disposal site}

Aquifers in the Uravan area are generally limited to the hydrostratigraphic units that have sufficient permeability to transmit ground water. The units that are capable of transmitting water in economic amounts include the Dakota Sandstone, the Burro Canyon Formation, the Salt Wash Member of the Morrison Formation, and the Entrada, Kayenta, and Wingate Sandstones. The strata that are not capable of transmitting water in economic amounts and that are therefore considered aquitards include the Brushy Basin Member of the Morrison Formation and the Summerville, Chinle, and Moenkopi Formations. The Chinle Formation underlies the Kayenta-Wingate aquifer and is the first hydrogeologic unit of concern in the Uravan area. All of the geologic units below this aquitard, which underlies the deepest water-bearing zone of concern, should not be affected by the migration of contaminated liquids (State of Colorado, 1983).

The Kayenta-Wingate sequence beneath Club Mesa includes a $400-\mathrm{ft}(122-\mathrm{m})$ sequence of sandstones with interbeds of shales. The lower part of this sequence is saturated, and observed water level elevations indicate that the ground water system in the Kayenta-Wingate is hydrologically connected to the San Miguel River. Data would also suggest that the gradient beneath Club Mesa is low. The direction of ground water flow is projected to be to the north and northeast.

Little is known about the Summerville and Entrada zones beneath Club Mesa; there appear to be some seasonal fluctuations and there are high concentrations of sulfate, chloride, and nitrate and a high level of TDS, but low water levels have made analysis extremely difficult.

There is no direct evidence of the presence of a saturated zone in the Salt Wash prior to the mining and disposal activities on Club Mesa. Waste disposal activities have contaminated the Salt Wash sandstone and formed a perched zone within this unit. If a saturated zone did exist prior to milling, it must have been extremely thin and perched above the Summerville aquitard. Cyclical variations in water levels have also been recorded in this unit. Water quality data indicate that most of the Salt Wash Member is contaminated beneath the tailings piles. For the most part, this contamination is in the form of high concentrations of sulfate, chloride, ammonia, and nitrate. In addition, thorium-230 and uranium have been found at elevated levels in several shallow monitoring sites. The present water surface is relatively shallow and parallels the surface topography, discharging from the canyon wall.

The regional ground water hydrogeology of the Uravan area has been described by Dames and Moore (1978) and International Engineering Company (1981). These reports may be referred to for additional discussions. 


\subsubsection{Dry Flats disposal site}

Ground water can occur in sandstone zones in the bedrock units beneath the Dry Flats disposal site. The bedrock units include (from the surface down) the Dakota Sandstone and Burro Canyon Formation of Cretaceous age and the Brushy Basin and Salt Wash Members of the Jurassic Morrison Formation. It is difficult to determine actual thicknesses and contacts between formations in the area because of similarities between the lithologies and gradational contact zones between the units. Near the disposal cell area, detectable ground water occurs initially (unconfined) as basal saturation in sandstones of the Burro Canyon Formation, which overlie the regional Brushy Basin aquitard at depths ranging from 185 to $200 \mathrm{ft}(56$ to $61 \mathrm{~m}$ ). The next occurrence of ground water (confined) is in sandstones in the lower part of the Brushy Basin Member at depths of approximately $500 \mathrm{ft}(152 \mathrm{~m})$. Based on the estimated thicknesses of units in the area, it appears that the top of the Salt Wash Member is approximately $700 \mathrm{ft}(213 \mathrm{~m})$ below the surface.

The shallower saturated sandstone zone in the basal portion of the Burro Canyon Formation is designated as the uppermost aquifer at the Dry Flats disposal site. Although this unit does not represent an aquifer from a water resource perspective, it could be classified as an aquifer from a regulatory perspective because it is the first zone of saturation on top of a regional aquitard and would be the first ground water affected by any potential seepage of leachate from the disposal cell.

Recharge to the sandstone zones beneath the Dry Flats disposal site is restricted to infiltration from precipitation. Downward migration of water is inhibited, particularly beneath the Burro Canyon Formation, by the thick mudstone in the Brushy Basin aquitard. There is no evidence of discharge of ground water from the shallower. Burro Canyon Formation along the contact with the Brushy Basin Member in the downslope drainages northeast of the site or in the cliff faces along the San Miguel River canyon.

Two seeps/springs in the Coke Oven Valley were observed within a 1-mi $(2-\mathrm{km})$ radius of the Dry Flats disposal site on the southwest side of the drainage divide. The origins of these discharges are most likely deep percolation from precipitation events and discharge of ground water from the Dakota Sandstone. Ground water in the Dakota on the southwest side of the drainage divide is relatively shallow in the Coke Oven Valley and has an upward gradient resulting in discharge to the surface drainage. A third seep/spring was observed within a $1-\mathrm{mi}(2-\mathrm{km})$ radius of the disposal cell. This perched water discharge is on the northeast side of the drainage divide. On this side, the Dakota Sandstone is unsaturated with the exception of localized occurrences of perched water. Some perched water from deep percolation may accumulate in near-surface sandstone units overlying more impermeable shale layers or in localized colluvial materials in the drainages. The origins of the discharge are most likely deep percolation from precipitation events and discharge of localized shallow perched water in the upper sandstone units. 
The direction of ground water flow in the shallower saturated zone of the Burro Canyon Formation is to the northeast, and the average hydraulic conductivity is relatively low. The potential yield of ground water from this zone is very low, less than 150 gallons (gal) [568 liters (L)] per day. The direction of ground water flow in the lower part of the Brushy Basin Member was not determined. Based on information from two deep monitor wells, there is an upward vertical gradient from the confined ground water in sandstones of the Brushy Basin Member.

Ground water quality in the shallower saturated zone of the Burro Canyon Formation was determined by analyzing samples taken during six sampling periods from August 1989 through July 1992. Ground water quality is characterized by activities of net gross alpha exceeding the MCL, with a mean activity of 37 picocuries per liter $(\mathrm{pCi} / \mathrm{L})$. The average concentration of TDS is $3203 \mathrm{mg} / \mathrm{L}$.

Within a $2-\mathrm{mi}(3-\mathrm{km})$ radius of the Dry Flats disposal site, there are several domestic water wells in the Coke Oven valley to the west and in the San Miguel River valley to the north. Of the three domestic wells in the Coke Oven valley, two are associated with a uranium leaching operation and one is for a private residence. The wells obtain ground water from the Dakota Sandstone. Ground water in the Dakota Sandstone in the Coke Oven valley is on the other side of a hydrologic divide from the Dry Flats disposal site, and no impacts from the disposal site would occur at these three wells. The wells in the San Miguel River valley tap the shallow alluvial and Salt Wash aquifers. There is no existing or potential use of the ground water in the uppermost aquifer (Burro Canyon Formation) in the immediate vicinity of the Dry Flats site because sustainable amounts of ground water are not available from the aquifer. However, the shallow perched water discharging from the observed seeps/springs within a $1-\mathrm{mi}(2-\mathrm{km})$ radius of the Dry Flats site is of beneficial use to livestock and wildlife.

\subsection{RADIATION}

The natural background gamma exposure rate at the Naturita processing site ranges from 11.8 to 15.1 microröentgens per hour $(\mu R / h r)$ and averages 13.5 $\mu \mathrm{R} / \mathrm{hr}$. Background surface soil samples collected within a few miles of the processing site indicated mean concentrations of $2.3 \pm 1.0 \mathrm{pCi} / \mathrm{g}$ for $\mathrm{Ra}-226$; $6.7 \pm 1.6$ parts per million for thorium-232 (Th-232); and $1.9 \pm 0.2$ percent for potassium-40 (K-40) (BFEC, 1985). Baseline radon concentrations averaged $2.0 \mathrm{pCi} / \mathrm{L}$ for the Naturita area and ranged from 1.0 to $3.2 \mathrm{pCi} / \mathrm{L}$ (FBDU, 1981).

Radiometric and soil sample analyses were made at and in the vicinity of the processing site to establish the extent and depth of contamination (Figure 4.1) (TAC, 1989; BFEC, 1985). The gamma exposure rate ranged from 8 to $369 \mu \mathrm{R} / \mathrm{hr}$ in the contaminated areas, with an area-weighted average of $39.1 \mu \mathrm{R} / \mathrm{hr}$ (ORNL, 1980). Ra-226 concentrations in soil ranged from 0.5 to $822 \mathrm{pCi} / \mathrm{g}$ in various areas around the site and had a volume-weighted average of $68.8 \mathrm{pCi} / \mathrm{g}$ (TAC, 1989; BFEC, 1985). In addition, eight buildings and 


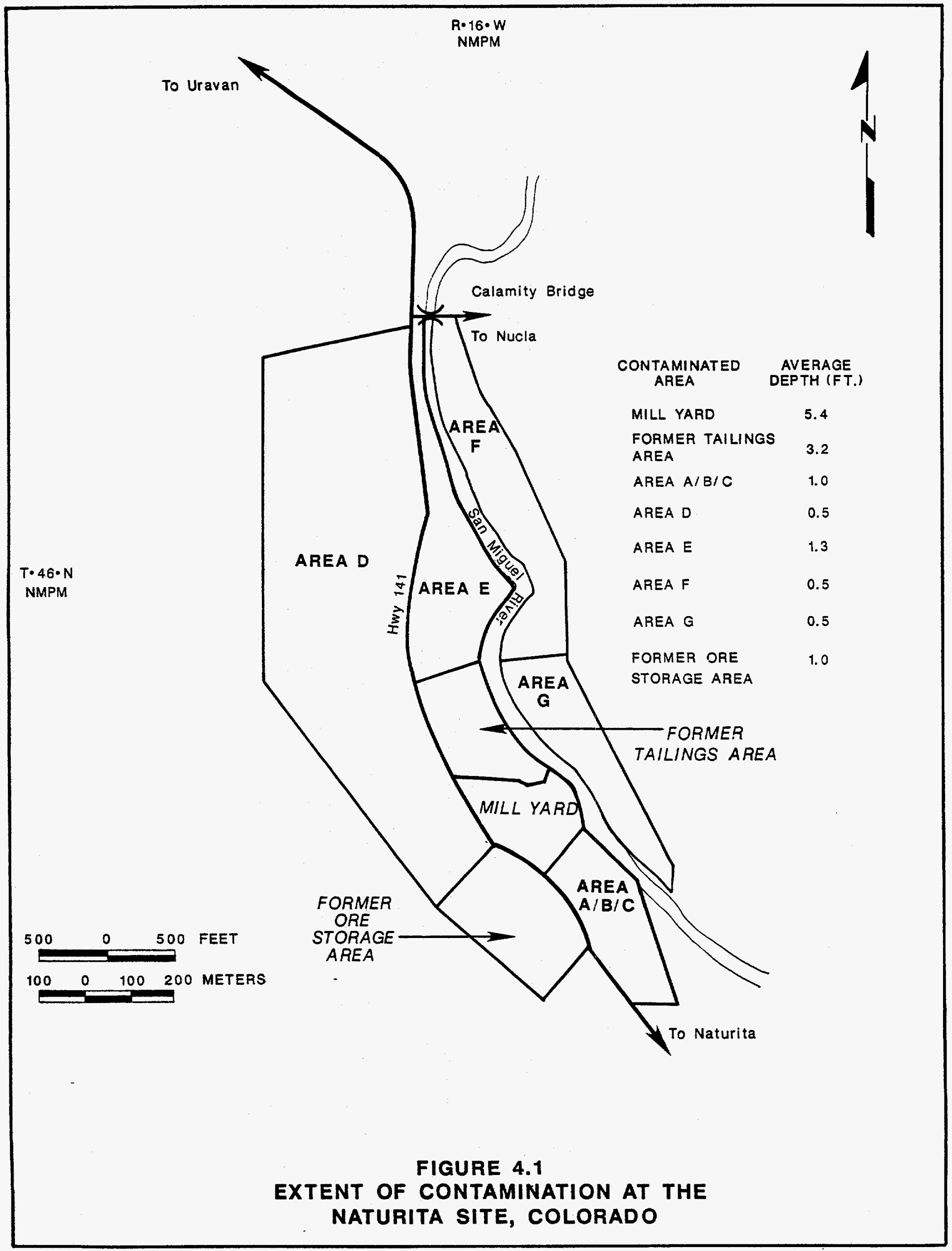


abandoned construction and mill equipment remain at the site. All of the buildings exhibit some alpha contamination, and gamma exposure rates are above the EPA standard of $20 \mu \mathrm{R} / \mathrm{hr}$ above background (BFEC, 1985).

Radon concentrations were measured at the site boundary from April 26, 1989, to March 12, 1990, using integrating Track-Etch ${ }^{\circledast}$ detectors (TAC, 1990). Concentrations ranged from 0.6 to $5.6 \mathrm{pCi} / \mathrm{L}$ and averaged $2.5 \mathrm{pCi} / \mathrm{L}$. Radon flux measurements were made at the site in 1981 using the charcoal canister technique (FBDU, 1981). Fluxes ranged from 0.5 to 124 picocuries per square meter per second $\left(\mathrm{pCi} / \mathrm{m}^{2} \mathrm{~s}\right.$ ) and had an area-weighted average of $20.2 \mathrm{pCi} / \mathrm{m}^{2} \mathrm{~s}$ for the mill yard and former tailings and ore storage areas.

Supplemental standards are defined under 40 CFR 192.22(a) as "coming as close to meeting the otherwise applicable standards as is reasonable under the circumstances." The bases for applying supplemental standards are 1) limited long-term health impacts; 2) unlikely human habitation of the area; 3) probable long-term environmental harm; 4) potential risk of injury to workers if remedial action were undertaken; and 5) unrealistically high remedial action costs relative to the benefits. Area $D$, west of the processing site and Colorado State Highway 141 (Figure 4.1), is considered for exclusion from remedial action by the application of supplemental standards. The rationale for applying supplemental standards to Area $D$ is based on a combination of radiological, ecological, geomorphological, and engineering considerations.

Radiological characterization of Area D identified 112 ac (45 ha) of land contaminated by Ra-226 that exceeded the EPA's surface cleanup criteria of $5 \mathrm{pCi} / \mathrm{g}$ above background $(2.3 \mathrm{pCi} / \mathrm{g})$. Ra- 226 concentrations ranged from 2 to $96 \mathrm{pCi} / \mathrm{g}$, with an average of $21 \mathrm{pCi} / \mathrm{g}$. Gamma exposure rate measurements ranged from 13 to $55 \mu R / h r$ and averaged $24 \mu R / h r$. If Area $D$ is not cleaned up, radiological impacts to individuals and the general population residing on or in the vicinity of the area could result from direct gamma exposure and the inhalation of radon decay products or resuspended radioactive particulates. The steep terrain of the area would rule out the likelihood of anyone permanently inhabiting or constructing a residence in the area; therefore, long-term health impacts due to on-site exposures are not a serious consideration. The radiological impacts to individuals and the general population residing in the vicinity of Area D would be negligible and are discussed in Section 5.4.

The terrain in Area D consists of steep, sparsely vegetated slopes cut by erosion gullies. Removing the contaminated materials from these slopes would require the removal of most, if not all, of the shallow soil and all associated vegetation. The vegetation in the area is considered to be rare by the state of Colorado (O'Kane, 1987, 1986; Voight, 1984), and removal of the upper few inches of soil would make the slopes sensitive to erosion. Successful revegetation of the disturbed area would be difficult, and severe erosion could bring mud and debris onto Colorado State Highway 141 unless the slopes were restabilized after remedial action. Furthermore, the steepness of the contaminated terrain would prevent the use of conventional excavation equipment normally used on the 
UMTRA Project and would present hazardous working conditions for the remedial action workers. The cleanup could cost three to five times the amount anticipated for other areas of the Naturita site.

It is evident from the above analysis that all the criteria for applying supplemental standards to Area $D$ have been met. The long-term health effects for an individual or the potentially exposed population would be negligible, and costly measures would be required to remove the contamination and restore the area to promote nonerosive drainage and reestablish rare plant communities. Finally, any construction activities on the steep terrain would be hazardous to remedial action workers. Therefore, an application for implementing supplemental standards in Area D would be submitted to the NRC and the state of Colorado for approval. If the application were approved, Area $D$ would not be included in the remedial action at the Naturita site.

Additional areas may be considered for the application of supplemental standards. These areas might include steep slopes where conventional cleanup techniques cannot be employed and where disturbances would likely cause future erosion problems and areas containing protected vegetation, wildlife habitat, or cultural resources.

\subsection{FLORA AND FAUNA}

This section describes the flora and fauna at and near the sites that could be affected by remedial action. Additional information on riparian plant communities and wetlands is provided in Attachment 1. Floodplains and Wetlands Assessment. Additional information on the flora and fauna and threatened and endangered species is provided in Attachment 2, Biological Assessment.

\subsubsection{Flora}

The San Miguel River Valley contains riparian areas surrounded by steep juniper-covered hillsides. Approximately 47 ac (19 ha) of riparian habitat along the San Miguel River have been contaminated at and adjacent to the Naturita processing site. The plant communities in this habitat are immature and mature cottonwood trees, cottonwood and willow seedlings and saplings, degraded cottonwood and willow saplings, upper riparian shrub, and willow. Other plant species in the riparian habitat include salt cedar, yellow sweet-clover, horsetail, sedges, rushes, Russian olive, squawbush, wild rose, grasses and herbs, rabbitbrush, and big sagebrush. Only the riparian areas containing the cottonwood and willow seedlings [approximately 4 ac (2 ha)] meet the USACE definition of a wetland (Jacobsen, 1992).

Vegetation in the area surrounding the Uravan site consists of three major community types: pinon-juniper woodland; sagebrush-grass community; and riparian zone. Small areas of mountain brush vegetation also occur where slopes are very steep and rocky (State of Colorado, 1983). 
The pinon-juniper woodland is a very widespread plant community type in the area around the Uravan site. It occurs on canyon slopes, on mesa tops, and at higher elevations on ridges than the sagebrush-grass community. The major canopy species in the pinon-juniper woodland are pinon pine and two species of juniper. Shrub species expected to be a part of the potential vegetation in this area include serviceberry, four-wing saltbrush, snowberry, mountain mahogany, bitterbrush, cliffrose, and Mormon tea. Understory species are primary grasses with a few forbs present (State of Colorado, 1983).

Riparian vegetation along Dry Creek near the Coke Oven borrow site generally grows in a thin band along the creek and is dominated by willow and salt cedar. Scattered clumps of mature cottonwood trees are also found along the creek.

Upland plant community types occur in elevated areas next to the San Miguel River riparian habitat and at the Dry Flats disposal and Coke Oven borrow sites. The upland plant community near the river is dominated by black greasewood, big sagebrush, rabbitbrush, and widely scattered juniper, pinon pine, and Gambels oak. Big sagebrush is the dominant plant species at the Dry Flats and Coke Oven sites. The pinon-juniper woods with an understory of big sagebrush grow near the Dry Flats site, and much of the haul road to the Dry Flats disposal site would traverse this plant community type. There are also areas of cleared sagebrush in the vicinity of the Dry Flats and Coke Oven sites. Big sagebrush has begun to reinvade these sites and is typically the most common species.

The sagebrush-grass community is found in canyon bottoms, on mesa tops, and on gentle, lower slopes of ridges. It often occurs as open parks within pinonjuniper vegetation where the two vegetation types intergrade. Big sagebrush, fringed sagebrush, and winterfat are the major shrub species (State of Colorado, 1983).

The riparian zone dominates in canyon bottoms near the San Miguel River. The species include tamarisk, narrowleaf cottonwood, willows, alders, and birch. Understory vegetation includes sedges and rushes. Small areas of mountain brush vegetation occur on steep and rocky slopes. Shrub species include serviceberry, four-wing saltbrush, skunkbush sumac, mountain mahogany, bitterbrush, snowberry, chokecherry, and elderberry (State of Colorado, 1983).

Small areas of mountain brush occur on very steep and rocky areas. Shrub species in this vegetation type include serviceberry, four-wing saltbrush, skunkbush sumac, mountain mahogany, bitterbrush, snowberry, cokecherry, and elderberry.

\subsubsection{Fauna}

Limited fish sampling in the San Miguel River indicates that the flannelmouth sucker and rainbow trout are the most common species. At least 11 species of reptiles and amphibians occur in the riparian habitat along the San Miguel River, while 14 species occur in the upland habitats. The Woodhouse toad, western 
whiptail, plateau striped whiptail, fence and sagebrush lizards, bull snake, and western terrestrial garter snake were observed.

A total of 78 species of birds were recorded at the Naturita site. Sixty-four species were observed in the riparian habitat, and 29 species were observed in the upland habitats. Of the 78 bird species, 16 were observed in both the riparian and upland habitats. Nesting bird surveys along the San Miguel River have shown that the yellow warbler is the most common species in the riparian habitat. Other common nesting species are the spotted sandpiper along the river, the western wood pewee and northern oriole in cottonwood stands, and the yellow-breasted chat in shrubby areas. Waterbirds such as the great blue heron, mallard, and belted kingfisher were frequently observed along the river but are not known to nest in the area. Nesting raptors were not observed in the site area. Turkey vultures have been roosting for a number of years in a cottonwood stand across the river from the processing site.

A total of 27 species of birds are known to nest in the riparian habitat along Dry Creek. The northern oriole, western kingbird, ash-throated flycatcher, and northern mockingbird were the most common species and were most frequently associated with the small stands of cottonwood trees along Dry Creek. The western meadowlark and rock wren were common in the big sagebrush habitat, while the blue-gray gnatcatcher and black-throated gray warbler were observed in the pinon-pine woods. No nesting raptors were observed in the area of the Dry Flats disposal and Coke Oven borrow sites, but the red-tailed hawk, American kestrel, and Cooper's hawk were observed. The prairie falcon, golden eagle, common barn owl, long-eared owl, great horned owl, western screech owl, and burrowing owl could occur in the areas of the Naturita, Dry Flats, and Coke Oven sites.

At least 19 species of mammals may occur in the riparian habitat along the San Miguel River, and 26 species may occur in the upland habitats. Beaver sign is common along the river and Dry Creek, and the mule deer is common along the river. Two small Gunnison prairie dog towns occur at the Dry Flats disposal and Coke Oven borrow sites. Mule deer sign was observed throughout the Dry Flats area, and the area may serve as winter range. There is no critical deer winter range in the area. A small number of elk may winter in the pinon-juniper woods in the area of the Dry Flats and Coke Oven sites.

The habitat types at the Uravan disposal site are very similar to those found at the Naturita processing, Dry Flats disposal, and Coke Oven borrow sites. Therefore, the fauna at the Uravan site would also be expected to be very similar.

\subsubsection{Threatened and endangered species}

Consultations with the FWS revealed that six federally listed threatened and endangered species, one federally proposed species, and nine federal candidate species may occur in the area of the Naturita processing. Dry Flats disposal, and Coke Oven borrow sites. The federally listed Colorado squawfish, bonytail 
chub, humpback chub, and razorback sucker were determined not to occur in the San Miguel River at the Naturita site. The federal candidate ferruginous hawk, loggerhead shrike, northern goshawk, Columbian sharp-tailed grouse, white-faced ibis, and Paradox lupine were also determined not to occur at or near the Naturita, Dry Flats, and Coke Oven sites.

The endangered bald eagle winters in small numbers along the San Miguel River in the processing site area but does not nest in the area. The endangered black-footed ferret is closely associated with prairie dog towns. However, due to the very limited number and size of prairie dog towns in the area, the black-footed ferret would not be expected to occur at or in the area of the Naturita, Dry Flats, and Coke Oven sites. The federal candidate flannelmouth sucker and roundtail chub reside in the San Miguel River in the area of the processing site. The willow flycatcher (subspecies not determined) was heard calling near the processing site in 1986. Subsequently, the southwestern willow flycatcher became a federal candidate species and is now proposed as endangered. The willow flycatcher was not observed or heard calling during surveys for the species in 1990 through 1994. This species does not currently nest in the processing site area, but potential habitat for the species does occur at the site.

Several threatened, endangered, and sensitive plant species are found or have potential habitat in the area around the Uravan site. The black-footed ferret has not been definitely sighted in the Uravan vicinity, but its habitat is present. Peregrine falcons may hunt waterfowl along the San Miguel River but more probably occur as migrants along the Dolores River, where prey such as waterfowl, shore birds, and passerine birds are more numerous. Sightings indicate that an aerie occurs in the area, but its location is unknown. The southern bald eagle hunts fish and feeds upon carrion along the rivers of the Dolores River basin. The northern bald eagle winters in the basin (State of Colorado, 1983).

\subsection{LAND USE}

Most of the land surrounding the Naturita processing site, Dry Flats disposal site, and Coke Oven borrow site is administered by the BLM and used primarily for livestock grazing. The closest residences to the processing site are 15 homes in East and West Vancorum (Latta, 1993) approximately 1 road mi $(2 \mathrm{~km})$ southeast of the site. The town of Naturita is approximately 1 air mi $(2 \mathrm{~km})$ northeast of the Dry Flats site, and there is one residence, the Coke Oven Ranch, approximately 2 air mi $(3 \mathrm{~km})$ west of the Dry Flats site.

Grazing by livestock and big game is the major land use in the vicinity of the Uravan site. The sagebrush and grass vegetation is very heavily grazed. A difference is grazing intensities between mesas on the north and south sides of the San Miguel River has been observed. Different livestock operators lease the grazing allotments of the two sides of the river and use different management 
practices. Mesa and bench vegetation on the north side of the river was more heavily used than that on the south side of the river (State of Colorado, 1983).

The former tailings area and mill yard are on private lands and are not being used at the present time. The former ore storage area is on private land and land administered by the BLM. The BLM-administered land is within the 23,236-ac (9403-ha) Sawtooth grazing allotment that is permitted for a total of 488 animal unit-months (AUM) between January 1 and April 30 of each year. (One AUM will meet the grazing needs of one mature cow and calf for one month.) The portion of the former ore storage area that is within the grazing allotment has steep slopes and probably does not receive much, if any, grazing use (Sazama, 1993). The portion of the former ore storage area that is on BLM-administered land is also within an active oil and gas lease (Lewis, 1993), but the steep slopes in this area probably preclude oil and gas exploration and development activities.

All of the contaminated areas adjacent to the processing site (Figure 4.1) except the area west of Colorado State Highway 141 (Area D) are on private lands. None of these private lands are being used except for one parcel south of the site, which is being used for the storage of surplus uranium processing equipment. The area west of Colorado State Highway 141 is on land administered by the BLM and is also within the Sawtooth grazing allotment and an active oil and gas lease. This area also has steep slopes and probably does not receive much if any grazing use or oil and gas exploration and development. The BLM-administered lands around the processing site are also a power site withdrawal (Sazama, 1993; Lewis, 1993).

The Dry Flats disposal site is on and surrounded by land administered by the $B L M$ and used primarily for livestock grazing. The site is within the 2387 -ac (966-ha) Lillylands-West grazing allotment, which is permitted for 224 AUMs of use between January 15 and March 31 of each year. The Dry Flats site is within a portion of the grazing allotment that was vegetatively treated by the BLM to improve forage production; this portion of the allotment probably produces 5 to 10 percent of the allotment's total forage production. There are two small earthen water tanks for livestock at the site. There are also private lands around the site. These private lands are used primarily for livestock grazing, and the inactive Durita uranium processing facility is on private land approximately 2 air mi $(3 \mathrm{~km})$ west of the Dry Flats site (Sazama, 1993). The Dry Flats site is also within two active oil and gas leases (Lewis, 1993).

The Coke Oven borrow site is also on land administered by the BLM and used primarily for livestock grazing. The site is within the 7660-ac (3100-ha) Coke Ovens grazing allotment, which is permitted for 224 AUMs between February 15 and April 15 of each year. There have been no vegetative treatments to improve forage production in the area of the site (Sazama, 1993). The Coke Oven site is within three active oil and gas leases and eight active lode mining claims (Lewis, 1993). 
County Road GG-25 crosses the Lillylands-West and Coke Oven grazing allotments and a very small corner of the East Paradox grazing allotment. The East Paradox grazing allotment is very large and is permitted for approximately 1200 to 1300 AUMs of use from December 15 to March 1 of each year. The corner of the East Paradox grazing allotment crossed by County Road GG-25 is probably not grazed or is grazed very infrequently (Sazama, 1994).

The Naturita area was evaluated for the presence of areas of critical environmental concern, prime and unique farmlands, wild and scenic rivers, and wilderness. None of these critical elements are present in the area (Pfifer, 1993).

\subsection{HISTORICAL AND CULTURAL RESOURCES}

The BLM has evaluated the potential for historical features (e.g., buildings and their contents) at the processing site, and certain features at the site have been recommended as eligible for nomination to the National Register of Historic Places (NRHP) (Kesterke, 1993). The Colorado State Historic Preservation Officer (SHPO) declared the Naturita processing site (former Vanadium Corporation of America mill site) eligible for listing in the NRHP (Hartmann, 1994). The SHPO determined that 9 of 13 individual structures at the site represent a unique type and method of construction and illustrate a particular manufacturing process for uranium ore.

Cultural resource surveys of the Naturita processing site and most of the adjacent contaminated areas were conducted from 1987 to 1993. Thirteen prehistoric sites and four isolated artifacts were recorded during these surveys. The sites consist of three rock shelters, several lithic scatters, and a petroglyph panel. Five of the sites are considered eligible for nomination to the NRHP, and additional data are required to determine the eligibility of four sites. The remaining four sites are not considered eligible for nomination to the NRHP (CASA, 1989a; 1993a). Additional cultural resource surveys will be conducted in the rest of the contaminated areas adjacent to the processing site.

Cultural resource surveys of the Dry Flats disposal site and haul road [County Road GG-25 and new $0.25-\mathrm{mi}(0.4-\mathrm{km})$ haul road] were conducted between 1987 and 1993. During these surveys, 11 prehistoric (or protohistoric) and historic sites and 14 isolated artifacts were located. The sites are one historic homestead, a possible wickiup, three rock shelters with lithic materials, two hearth sites with lithic materials, and four lithic scatters. Five of the sites are considered eligible for nomination to the NRHP, and additional data are required to determine the eligibility of one site. The remaining five sites are not considered eligible for nomination to the NRHP. Only one isolated artifact was found in the area of the haul road (CASA, 1990a; 1989b).

Cultural resource surveys of the Coke Oven borrow site were conducted in 1989,1990 , and 1993. Seven prehistoric sites and 19 isolated artifacts were located during these surveys. The sites are two rock shelters with lithic 
materials and five lithic scatters. Four of the sites are considered eligible for nomination to the NRHP, and one of the sites is not considered eligible for nomination to the NRHP. Additional data are required to determine the eligibility of the other two sites (CASA, 1993b; 1990a; 1990b; 1989b).

There are no known areas of religious significance to Native Americans in the Naturita area (Fike, 1993).

\subsection{SOCIOECONOMIC CHARACTERISTICS}

The Naturita processing site is in the western portion of Montrose County, which is characterized by smaller, rural communities. In 1990, the population of Montrose County was 24,423 . Most of this population ( 72 percent) resides in the eastern portion of the county, which is called the Montrose census subdivision. The Nucla census subdivision represents the western portion of the county and includes the Naturita site. Nucla is approximately 3 road mi $(5 \mathrm{~km})$ north of Naturita. In 1990, the Nucla census subdivision had a population of 2289, and Naturita and Nucla had populations of 434 and 656, respectively (DOC, 1991a). Recent estimates indicate that the populations of these communities have remained stable. The 1992 estimated populations of Naturita and Nucla were 461 and 699, respectively (Reynolds, 1993). Based on 1990 data, Montrose County had an average household size of 2.55 persons and a population density of 10.9 persons per square mile. The 1990 average household size for the Nucla census subdivision was 2.5 persons (DOC, 1991b).

The 1990 total civilian labor force in Montrose County was 11,170 persons with a 6.1 percent unemployment rate. For the Nucla census subdivision, the 1990 civilian labor force was 957 persons, and the unemployment rate was 6.5 percent. The 1990 civilian labor forces in Naturita and Nucla were 184 and 278 persons, with unemployment rates of 3.8 and 9.4 percent, respectively. The 1990 unemployment rate for the state of Colorado was 5.7 percent (DOC, 1991c). A coal-fired electric power plant and supporting coal mine recently went into full production in the Nucla area, and there has been increased construction in the nearby Telluride area (Latta, 1993). Correspondingly, labor trends indicate that unemployment is decreasing in Montrose County. In July of 1993, the county had a total civilian labor force of 12,254 persons with a 5.3 percent unemployment rate (Holiday, 1993; Larson, 1993).

In 1990, Montrose County had 10,353 housing units, and 9405 of these units were occupied. Owner-occupied units made up 72 percent of the housing units. Vacancy rates in Montrose County were 1.8 percent for homeowner units and 8 percent for rental units. These rates were below the state's vacancy rates of 3.3 percent for homeowner units and 11.4 percent for rental units, reflecting a tighter housing market for both types of units. The Nucla census subdivision had 1195 housing units in 1990, and 915 of these units were occupied. Of the 280 vacant units, 57 were for seasonal, recreational, or occasional use. In 1990, Naturita had 230 housing units, of which 43 were renter-occupied and 
50 were vacant. Nucla had 338 housing units in 1990. Of these units, 83 were renter-occupied and 63 were vacant (DOC, 1991a, 1991d).

Recent activities in the Nucla and Telluride areas have caused a shortage of available housing, both owner-occupied and rental, in Naturita and Nucla. In fact, almost all of the rental housing in Naturita is rented or has been purchased for permanent housing. People working in the Telluride area tend to seek housing in Naturita and Nucla because housing in Telluride and Norwood is expensive. Telluride and Norwood are approximately 60 and $20 \mathrm{road} \mathrm{mi} 197$ and $32 \mathrm{~km}$ ) southeast of Naturita, respectively. Two trailer parks in Naturita and Nucla have approximately 20 vacant trailer spaces, and one recreational vehicle park in Naturita has 10 to 12 spaces (Crane, 1993; Latta, 1993). Two motels in Naturita have a total of 62 rooms (Hall, 1993; Hopkins, 1993).

Naturita and Nucla make up the West End School District. The Naturita Middle School (grades 7 and 8 ) is in Naturita and has a current enrollment of 89 students. The elementary (preschool through grade 6) and high schools are in Nucla. The Nucla Elementary School has a current enrollment of 350 students, and the Nucla High School has a current enrollment of 125 students. The Naturita Middle School and Nucla Elementary School could accommodate a maximum of 15 and 50 additional students, respectively, without providing additional facilities and personnel. The Nucla High School has sufficient classroom space to accommodate additional students, but the teacher-tostudent ratio is at or very near capacity. Depending on the number and grades of additional high school students, at least one part-time teacher might have to be hired (Hopewell, 1993; Mahaney, 1993; Harrison and Kelly, 1993).

Three Montrose County deputy sheriffs stationed in Naturita patrol the NaturitaNucla area. There is an auxiliary sheriff's office in Nucla, and there is also a volunteer sheriff's posse. The town of Nucla has just hired a police officer. The Colorado State Patrol passes through the area at least once a day. Naturita and Nucla share a combined volunteer fire department with approximately 40 firefighters. There is a fire station in each town, and the fire department has three ambulances (Thomson, 1993; Vodopich, 1993).

Emergency medical care and outpatient services are available from clinics in Naturita and in Norwood, approximately 20 road mi $(32 \mathrm{~km})$ southeast of Naturita. Emergency medical calls are dispatched through the sheriff's office in Naturita. For extensive medical care, patients may be taken to Montrose, Grand Junction, or, if necessary, to Denver, Colorado (Kettle, 1993). Montrose Memorial Hospital has a capacity of 75 beds with an average occupancy rate of approximately 50 percent (Holman, 1993).

\subsection{TRANSPORTATION}

The Naturita processing site is accessible from Naturita on Colorado State Highways $90 / 141$ and 141 ; from the Uravan disposal site on Colorado State Highway 141; and from the Dry Flats disposal site on Colorado State Highways 
90 and 141 and County Road GG-25. Colorado State Highways 90, 141, and 90/141 are paved, two-lane roads; County Road GG-25 is a dirt road. The 1994 average daily traffic on Colorado State Highways 90 and 141 at their intersection is projected to be 360 and 281 vehicles, respectively. The capacities of Colorado State Highways 90 and 141 at level of service "A" are 45 and 39 vehicles per hour, respectively. From 1987 to 1992, there were two injury accidents and four property-damage only accidents on Colorado State Highways 90 and 141 at their intersection. There were no fatal accidents at this location during this period (Langoni, 1993). 


\subsection{ENVIRONMENTAL IMPACTS}

\subsection{INTRODUCTION AND ASSUMPTIONS}

The environmental impacts of the proposed action and no action are discussed in this section. The environmental impacts are generally based on conservative assumptions and impact assessment procedures and thereby represent a realistic upper limit on the severity of the impacts that may occur. The actual impacts that would occur would probably be less severe than those identified here.

The impacts presented here are also based on the assumption that an application for supplemental standards would be approved for Area D adjacent to the Naturita processing site (Sections 3.1, 4.5, 5.4, and 5.9); this approval would preclude performing remedial action for Area $D$. If the application were not approved, the public health impacts after remedial action would decrease very slightly. However, health impacts to remedial action workers could increase substantially, primarily due to the potential physical hazards associated with conducting remedial action in this area. Other environmental impacts (e.g., erosion and the destruction of vegetation) could also increase substantially if the cleanup of Area D were required. Appropriate analysis prior to the start of remediation would be conducted to ensure that no unacceptable impacts occur as a result of these activities.

Additional areas at and adjacent to the Naturita processing site may be considered for the application of supplemental standards. These areas might include steep slopes and areas containing protected vegetation, wildlife habitat, or cultural resources. Remedial action in these areas could be costly and hazardous to remedial action workers and could result in long-term environmental impacts such as increased erosion. If supplemental standards were applied to additional areas, the public health impacts after remedial action would increase slightly, but the health impacts to remedial action workers could decrease substantially. Other environmental impacts of the remedial action, such as the disturbance of riparian plant communities and cultural resources, could be reduced if supplemental standards were applied to additional areas.

\subsection{NO ACTION}

Without any remedial action at the Naturita processing site, the RRM would remain where they are. The RRM would continue to be exposed to erosion from surface runoff and flood flows from the San Miguel River, and eventual erosion of the RRM could result in the transport of contaminants into the river. The Naturita site and adjacent areas would remain unusable and would continue to decrease the value of adjacent lands. The RRM would be susceptible to unauthorized removal and use by humans, which could cause more widespread contamination and increased public health hazards. The contamination of ground water at the processing site would continue for an indefinite period of 
time. The Dry Flats disposal site would not be transferred to the DOE, and the public lands within the Dry Flats site would continue to be administered by the BLM. Finally, without remedial action at the Naturita processing site, the requirements of PL 95-604 would not be met.

\subsection{GENERAL IMPACT SUMMARY}

The impacts identified for the Uravan disposal alternative are the impacts of remedial action at the Naturita processing site and, when appropriate, the impacts along the transportation route to the Uravan site (Colorado State Highway 1411.

Disposal at the Uravan site would be consistent with the EPA standards for active (Title II) uranium processing sites (40 CFR Part 192) and other appropriate authorizations. The disposal action would be performed in accordance with a disposal plan prepared by the owner and operator of the Uravan site and approved by the CDPHE.

In August 1978, an environmental report was submitted to the CDPHE/RCD. The environmental report was undertaken to comply with the NEPA requirements at that time. As part of the radioactive materials license evaluation, a final licensing statement was issued by CDPHE/RCD in December 1986. Portions of the final licensing statement (FLS) contained CDPHE/RCD's evaluation of the environmental information consistent with the NEPA process. In 1992, an application was submitted to CDPHE/RCD to amend the existing radioactive materials license. In support of the proposed license amendment, the original environmental report was updated and submitted for review on December 21, 1992. Analogous to the original procedure, CDPHE/RCD issued its licensing statement for the amended license on January $28,1993$.

The proposed remedial action would have no effect on the climate or geology of the affected areas, although it is recognized that both of these elements could affect the longevity of the proposed engineering design for either the Uravan or the Dry Flats disposal alternative's compliance with the proposed EPA ground water protection standards for inactive (Title I) uranium processing sites. The engineering design elements that would mitigate erosion for the Dry Flats disposal alternative include the 2- to 5-percent slopes of the Dry Flats disposal cell (Figure 3.1 ) and the riprap [ 1.5 to 3.5 in $(3.8$ to $8.9 \mathrm{~cm})$ in diameter] covering the disposal cell. The Dry Flats disposal site was selected as a candidate disposal site because it is in an area of geologic stability and would not be subject to natural processes that could jeopardize the integrity of the disposal cell.

It is highly unlikely that any usable minerals (e.g., oil, gas, and coal) are present beneath the Dry Flats disposal site (Section 4.2). The UMTRCA, PL 95-604, also authorizes the Secretary of the Interior, with the concurrence of the Secretary of Energy and the NRC, to dispose "of any subsurface mineral rights by sale or lease...if the Secretary of the interior takes such action as the 
Commission deems necessary pursuant to the license issued by the Commission to assure that the residual radioactive materials will not be disturbed by reason of any activity carried on following such disposition." The transfer of the mineral rights for the Dry Flats site to the federal government would be subject to any valid existing mineral rights (e.g., oil and gas leases).

There would be no significant deterioration of air quality during the proposed remedial action. The most important air pollutant of concern would be uncontrolled fugitive dust, and much of the fugitive dust would be produced along the unpaved portions of the haul road to the Uravan or the Dry Flats disposal sites. It is assumed that using water, chemical additives, or a combination of water and additives as a dust suppressant would effectively reduce emissions by at least 50 percent. Covering the haul trucks or using surfactants on their contents would also reduce fugitive dust. An Air Pollution Emissions Notice and Emission Permit would be obtained from the state of Colorado prior to beginning the remedial action. This permit would require implementation of a dust control plan that would include measures such as covering haul trucks, treating haul roads, limiting speeds on unpaved haul roads, and stopping work during windy periods. A monitoring plan to ensure that air quality standards are not exceeded would be developed by the RAC and must be approved by the state of Colorado and Montrose County before any grounddisturbing activities are initiated.

For the Uravan or the Dry Flats disposal alternative, remedial action at the Naturita processing site would remove soils from approximately 133 ac (55 ha). These soils are contaminated and cannot be used for agricultural, commercial, or other purposes. Disturbed areas at and adjacent to the processing site would be reclaimed with uncontaminated soils.

During the Dry Flats disposal alternative, activities at the Dry Flats disposal site would permanently disturb approximately 28.5 ac (11.2 ha) of soils for the excavation of the disposal cell [21 ac ( 8 ha)], improvement of County Road GG25 [ 7 ac ( $3 \mathrm{ha})$ ], and construction of the new haul road from the county road to the disposal site [0.5 ac (0.2 ha)]. This disturbance would constitute a permanent loss of soils, but these soils would be used for part of the disposal cell cover or for restoration of the Naturita processing site. Approximately 84.5 ac (34.2 ha) of soils would be temporarily disturbed at the Dry Flats disposal site by the construction of the disposal cell [48 ac (19 ha) within the temporary disposal site and 36 ac (15 ha) within the final disposal sitel and construction of the new haul road [0.5 ac (0.2 ha)]. A maximum of 135 ac (55 ha) of soils would be temporarily disturbed at the Coke Oven borrow site. Surface soils in areas to be temporarily disturbed would be scraped, stockpiled, and used to reclaim the sites after completion of the remedial action. A total of approximately 380 ac (153 ha) of soils would be permanently and temporarily disturbed by the Dry Flats disposal alternative.

The disturbed areas at and adjacent to the processing site would be reclaimed with uncontaminated soils, and it is anticipated that these uncontaminated soils 
would be obtained from existing, privately owned, commercial borrow sites in the vicinity of the processing site. This would preclude the surface disturbance associated with using the Coke Oven borrow site. If the Coke Oven borrow site were used as a source of uncontaminated soils for reclamation of the processing site, the amount of surface disturbance could be less than that for the Dry Flats disposal alternative due to the lesser amount of borrow materials required. Approximately 3 ac ( 1 ha) of soils would be permanently disturbed by the improvement of County Road GG-25 to the Coke Oven borrow site if this borrow site were used. The use of the Uravan site would preclude the surface disturbance associated with construction of the Dry Flats disposal site.

\subsection{RADIATION}

The principal pathways by which individuals could be exposed to radiological hazards during the remedial action include the inhalation of radon decay products and airborne radioactive particulates, direct exposure to gamma radiation, ingestion of contaminated surface water and ground water, and ingestion of foods produced in contaminated areas. The ingestion of contaminated water and food is not of major concern at the Naturita site, as no water supply wells or agricultural areas have been or would be adversely affected. Calculations of excess health effects from the ingestion of contaminated water from a hypothetical well were considered and shown to be low relative to those from the inhalation and direct exposure pathways. Therefore, excess health effects to the general population were calculated only for the inhalation of radon and radon decay products, direct exposure to gamma radiation, and the inhalation of airborne particulates. The excess health effects during remedial action were calculated only for the Dry Flats disposal alternative. However, these calculations are also representative for the Uravan disposal alternative. The assumptions and detailed calculations for the radiological health impacts are available for review in the UMTRA Project Office in Albuquerque, New Mexico.

Excess health effects are the number of fatal cancers that are estimated to occur in a population due only to the exposure to radiological contaminants associated with the processing and disposal sites and remedial action activities. To put the excess health effects in perspective, an individual in the United States has a 16 percent lifetime chance of contracting a fatal cancer, or one chance in six, due to all other causes in society (NAS, 1980).

During the implementation of the proposed action, the exposure to the general population from the radiological pathways would decrease as the RRM are removed to the selected disposal site. Remedial action workers would be exposed to contamination during remedial action. However, mitigative measures such as wetting the work areas or stopping work during high winds would be implemented during remedial action to keep airborne radioactive particulate concentrations at a nonhazardous level. No credit was allowed in the excess health effects calculations for the effectiveness of mitigative measures. 
As shown in Table 5.1, the increase in general population excess health effects due to radon released from the Naturita RRM during remedial action would be smaller than the number of excess health effects without remedial action. This is because radon is currently emanating from the processing site. During remedial action, increases in gamma exposure rates and airborne radioactive particulates would be confined to the close vicinities of the Naturita processing and Dry Flats disposal sites. Since the general population densities at the sites are low, these increases would mainly affect remedial action workers. Also, as shown in Table 5.1, the excess health effects to the general population due to gamma radiation exposure and particulate releases would be nearly two orders of magnitude less than those caused by radon decay products. For an individual in the exposed population of 1501 persons within $6 \mathrm{mi}(10 \mathrm{~km})$ of the processing site, the total risk for the proposed remedial action would correspond to 1 chance in 5.2 million of an individual contracting a fatal cancer per year of exposure, or 1 chance in 74,000 over a 70-year lifetime. This would be a small increase compared with the natural lifetime incidence of cancer in the United States. However, the increased risk of excess health effects would continue for thousands of years without remedial action.

Table 5.1 Excess health effects for the general public and remedial action workers ${ }^{a}$

\begin{tabular}{ccccc}
\hline & $\begin{array}{c}\text { Radon decay } \\
\text { products } \\
\text { exposure } \\
\left(\times 10^{-4}\right)\end{array}$ & $\begin{array}{c}\text { Gamma } \\
\text { exposure } \\
\left(\times 10^{-4}\right)\end{array}$ & $\begin{array}{c}\text { Airborne } \\
\text { radioactive } \\
\text { particulates } \\
\left(\times 10^{-4}\right)\end{array}$ & $\begin{array}{c}\text { Total excess } \\
\text { health effects } \\
\left(\times 10^{-4}\right)\end{array}$ \\
\hline $\begin{array}{c}\text { General public } \\
\text { Proposed action }\end{array}$ & 2.8 & 0.021 & 0.049 & 2.9 \\
No action $^{b}$ & 3.9 & 0.065 & NC & 4.0 \\
$\begin{array}{c}\text { Remedial action workers } \\
\text { Proposed action }\end{array}$ & 12 & 4.9 & 6.3 & 23 \\
No action & 0 & 0 & 0 & 0 \\
\hline
\end{tabular}

${ }^{a}$ An excess health effect of $10^{-4}$ or 0.0001 corresponds to 1 chance in 10,000 of an individual contracting a fatal cancer per year of exposure. The excess health effects for the general public are based on a population of 1501 persons within $6 \mathrm{mi}(10 \mathrm{~km})$ of the processing and Dry Flats disposal sites. The excess health effects due to the proposed action were calculated for a typical remedial action scenario (e.g., typical sequence for the excavation of RRM and restoration of disturbed areas) and schedule. A different remedial action scenario and/or schedule would result in a different but very similar number of excess health effects.

${ }^{b}$ The excess health effects for no action are for a 36-month period to allow a direct comparison with the excess health effects due to 36 months of remedial action. The 36-month remedial action period includes two 4-month winter shutdowns. The excess health effects for no action do not include the health effects due to no action at the off-site vicinity properties.

'The excess health effects from airborne radioactive particulates for no action were not calculated (NC). Previous calculations of these health effects have shown them to be orders of magnitude less than those from radon decay products and gamma radiation. 
Due to their proximity to the Naturita RRM, remedial action workers would also be exposed to radon decay products, gamma radiation, and airborne radioactive particulates. During remedial action, individual workers would receive whole-body doses of approximately 40 millirems (mrem) from gamma exposure at the processing site and approximately $30 \mathrm{mrem}$ at the Dry Flats disposal site. The excess worker health effects from gamma exposure during remedial action would be $4.9 \times 10^{-4}$.

Remedial action workers would also receive radiation doses from the inhalation of airborne radioactive particulates. Individual workers at the processing and disposal sites would receive 50 -year effective whole-body dose commitments of approximately $50 \mathrm{mrem}$ and $130 \mathrm{mrem}$, respectively. The excess health effects to workers from exposure to airborne radioactive particulates during remedial action would be $6.3 \times 10^{-4}$. The combined dose from gamma radiation and airborne radioactive particulates exposure for a worker at each site would be approximately 80 mrem for the processing site and 160 mrem for the Dry Flats disposal site. Both of these doses are less than 4 percent of the standard established by DOE Order 5480.11, Radiation Protection for Occupational Workers. In addition, dust control and the use of respirators could greatly reduce workers' inhalation of airborne radioactive particulates.

Exposure to radon decay products would contribute the greatest number of excess health effects (about 52 percent) to remedial action workers. Workers at the processing and Dry Flats disposal sites would be exposed to an average radon concentration of approximately $0.4 \mathrm{pCi} / \mathrm{L}$. This value is well below the EPA's recommended annual average radon action level of $4 \mathrm{pCi} / \mathrm{L}$ for an occupied dwelling. The lifetime risk for remedial action workers would be four times greater than that for an individual member of the general public exposed to radon decay products during the 33-month remedial action.

Following remedial action, radon releases from the processing site would be reduced because the RRM would be removed to either the Uravan disposal site or the Dry Flats site and covered with the compacted radon barrier and frost protection layer. The post-remedial-action radon releases from the Dry Flats disposal site would be no greater than the $20 \mathrm{pCi} / \mathrm{m}^{2} \mathrm{~s}$ limit allowed by the EPA standards (40 CFR Part 192). The Dry Flats disposal cell cover would essentially eliminate excess health effects to the general public from gamma radiation and airborne radioactive particulates. In addition to the exposure of . the general public to low radon concentrations from the Dry Flats disposal site, radon would emanate at a rate of $4.3 \mathrm{pCi} / \mathrm{m}^{2}$ s from Area $D$ near the processing site; this radon would be atmospherically dispersed to the population. The total excess health effects to the general public from the Dry Flats disposal site and Area D would be $3.9 \times 10^{-5}$ per year $\left(2.0 \times 10^{-5}\right.$ excess health effects per year from Area D). No action would result in $24 \times 10^{-5}$ excess health effects per year. 


\subsection{SURFACE WATER}

During the Uravan or Dry Flats disposal alternative, the cleanup of the RRM at the Naturita processing site would result in surface disturbance, and surface water runoff from disturbed areas could be contaminated. In addition, contaminated wastewater would be generated by activities such as equipment washing. The remedial action design includes the construction of drainage and erosion controls, including lined wastewater retention ponds, to prevent the discharge of contaminated water from the site. These control measures would be constructed according to applicable regulations. The contaminated water would be retained for evaporation or for use in compacting the contaminated materials if the Dry Flats disposal alternative were selected. Any sediments from the wastewater retention ponds would be consolidated with the other RRM at the selected disposal site. Appropriate drainage and erosion controls, including lined wastewater retention ponds, would also be used at the Dry Flats disposal and Coke Oven borrow sites to prevent or minimize erosion and any associated surface water impacts.

The removal of RRM from the former tailings area and mill yard would disturb approximately 31 ac (13 ha) within the 100-year floodplain of the San Miguel River. Clean fill material would be placed in the disturbed areas concurrently with the removal of the RRM to minimize any increase in the width of the 100 year floodplain. The man-made terraces in the mill yard would be replaced with a gentle slope that would slightly increase the width of the 100-year floodplain, and approximately 38 ac (15 ha) of the processing site would be within the 100-year floodplain after the remedial action. In the vicinity of the processing site, migration of the eastern bank of the San Miguel River is constrained by a resistant mudstone, and the western bank would be restored to a gentle slope with clean fill material after the remedial action. The gentle slope would not restrict the river's flow, and the clean fill material would not be expected to be more susceptible to erosion than naturally deposited river sediments. Therefore, the remedial action would not affect the path or flow regime of the San Miguel River in the vicinity of the Naturita site.

Disposal of the Naturita RRM at the Uravan disposal site would be consistent with the EPA standards for active (Title II) uranium processing sites (40 CFR Part 192) and other appropriate authorizations. The disposal action would be performed in accordance with a disposal plan prepared by the owner and operator of the Uravan site and approved by the CDPHE. Compliance with the applicable floodplain regulations at the Uravan site would be the responsibility of the owner and operator of the site. If County Road EE-22 were improved for the transportation of the Naturita RRM to the Uravan site, the DOE would comply with the applicable floodplain regulations for the improvement and use of this road.

After completion of the Dry Flats disposal alternative, surface water runoff would not cause erosion of the Dry Flats disposal cell and transport contaminants into local surface waters because of the erosion control features incorporated into the remedial action design (Figures 3.1 and 3.2). The topslope 
and sideslopes of the Dry Flats disposal cell would be limited to 5 percent and 5 horizontal to 1 vertical, respectively, to promote drainage from the cell at nonerosive flow velocities. The topslope and sideslopes would be covered with riprap to resist the erosive forces of the local probable maximum precipitation (PMP) storm, which is a severe rainfall event. To protect against erosion due to runoff from the Dry Flats disposal cell, rock aprons (rock-filled trenches) would be placed at the bottom of the sideslopes (Figure 3.1) to provide protection against undercutting during the local PMP storm. The ground surface adjacent to the bottom of the Dry Flats disposal cell would be graded to direct runoff evenly away from the cell to downgradient areas and to reduce the velocity of the runoff to minimize potential erosion.

The Uravan and Dry Flats disposal alternatives could both require the removal of earthen materials at the Coke Oven borrow site. Removal of this material could disturb the Mancos Shale or soils that are derived from the Mancos Shale. The Mancos Shale is saline, and this disturbance could cause increased salt concentrations in surface water runoff from the disturbed areas (Jackson and Julander, 1982). Appropriate drainage and erosion controls would be implemented at the borrow site to prevent or minimize erosion and any associated surface water impacts during remedial action. The borrow site would then be restored in accordance with the Free Use Permit issued by the BLM and the Mined Land Reclamation Permit issued by the Colorado Department of Natural Resources, Division of Minerals and Geology. The restoration would include measures to control erosion and to promote sheet flow drainage, which would prevent or minimize increased salt concentrations in surface water runoff from the borrow site.

\subsection{GROUND WATER}

The disposal cell at the Dry Flats site has been designed to control radioactive materials and nonradioactive contaminants in compliance with the proposed EPA ground water protection standards in 40 CFR 192.01(a)(3). The proposed compliance strategy for the protection of ground water resources would be a supplemental standard for ground water in the uppermost aquifer (Burro Canyon Formation), based on limited-use ground water (Class III) because of low yield [40 CFR 192.11(e)]. The potential yield of ground water from the uppermost aquifer is low [less than $150 \mathrm{gal}(568 \mathrm{~L})$ per day], and the average hydraulic conductivity is relatively low. There is minimal recharge to ground water in this aquifer and no evidence of discharge of ground water from the uppermost aquifer anywhere in the site vicinity. There is no existing or potential use of the ground water in the uppermost aquifer in the immediate vicinity of the Dry Flats site because sustainable amounts of ground water are not available from the aquifer. Localized occurrences of shallow perched water in the Dakota Sandstone are not considered a part of the uppermost aquifer.

Disposal of the Naturita RRM at the Uravan disposal site would be consistent with the EPA standards for active (Title II) uranium processing sites (40 CFR Part 192). These standards are essentially the same as those for inactive sites. 
Disposal at the Uravan site would be performed pursuant to a disposal plan prepared by the owner and operator of the site and approved by the CDPHE.

The protection of human health and the environment at the Dry Flats disposal site would be ensured by a combination of design features and advantageous hydrogeologic conditions. The low rate of infiltration through the multilayered disposal cell cover and the low transient drainage from the RRM would result in unsaturated flow that would be accepted into storage in the unsaturated zone in the underlying Dakota Sandstone and Burro Canyon Formation. Any ground water resource at depth in the Salt Wash Member would be adequately protected from the migration of any potential site-related contamination in the Burro Canyon Formation by the hydrogeologic isolation afforded by the thickness of mudstone (low-permeability aquitard) in the upper part of the Brushy Basin Member and the upward ground water gradient from the lower Brushy Basin sandstones. The appropriate method for ground water compliance monitoring of the Dry Flats disposal site would be determined and described in the long-term surveillance plan.

Removal of the Naturita RRM would eliminate the source of any future ground water contamination at the processing site. The cleanup and/or control of existing ground water contamination at the processing site will be evaluated during the ground water restoration phase of the UMTRA Project and will be a part of a separate NEPA review process. The proposed remedial action would not preclude or interfere with ground water remediation, should it be required, because the RRM would be relocated to either the Dry Flats disposal site or the Uravan site.

\subsection{FLORA AND FAUNA}

Flora and fauna would be affected directly and indirectly by the proposed remedial action. Direct effects would include the loss of habitat, loss of less mobile wildlife species, and displacement of other wildlife species. Indirect effects would arise from increased fugitive dust, noise levels, and human activity. The duration of the direct effects would depend on the level of restoration, and indirect effects would be for the duration of the remedial action or less.

Remedial action at the Naturita processing site with disposal at the Uravan facility would disturb approximately 87 ac ( $35 \mathrm{ha}$ ) of land. The majority of this land consists of riparian vegetation [47.5 ac (19.2 ha)] and previously disturbed ground with little vegetation [40 ac (16 ha)]. The riparian plant communities along the river are dominated by cottonwood and willow. Impact at the Uravan facility would be minimal, because the area designated for disposal of the Naturita RRM is currently licensed for the disposal of mill ores, milling residues, tailings, and refuse by the CDPHE.

Remedial action at the Naturita processing site with disposal at the Dry Flats site would disturb approximately 380 ac (153 ha) of land. The majority of this 
land consists of upland sagebrush and pinon-juniper plant communities [ 292.5 ac (118.4 ha)], followed by riparian vegetation [47.5 ac (19.2 ha)] and previously disturbed ground with little vegetation [40 ac (16 ha)]. The riparian plant communities along the river are dominated by cottonwood and willow. These plant communities are productive in terms of flora and fauna and are relatively scarce in the region. Consultation with the USACE indicated that only the 4 ac (2 ha) of cottonwood/willow seedlings meet the USACE definition of a wetland (Attachment 1). The remaining riparian plant community types do not meet the USACE definition of a wetland because they lack the proper hydrological conditions or moist soils (Jacobsen, 1992). The 292.5 ac (118.4 ha)] of sagebrush and pinon-juniper plant communities represent the second most productive habitat types that would be disturbed. These habitat types are common in the area, and the land to be affected is not in any important wildlife habitat (e.g., critical deer winter range). The USACE has not inspected the riparian plant communities along Dry Creek. It was assumed that the 0.5 ac $(0.2 \mathrm{ha})$ of riparian plant communities that could be disturbed by improving the Dry Creek crossing of County Road GG-25 would meet the USACE definition of a wetland.

The clearing of vegetation from the riparian areas would temporarily reduce or prohibit wildlife use. The duration of this effect would depend on the level of restoration undertaken. Remedial action at the Naturita processing site would remove not only the vegetation but also some of the soil. This soil could not be stockpiled because it is contaminated and must be removed to the selected disposal site. Prior to any surface disturbance, plans for the restoration of excavated areas would be developed by the RAC and the DOE in consultation with the appropriate regulatory agency or other authority. In general, these plans would involve backfilling, recontouring, and revegetation. Effects would be mitigated by performing restoration as soon as possible after the completion of surface-disturbing activities. The DOE would mitigate remedial action impacts to wetlands as determined by the USACE Section 404 Permit process. This permit process usually includes review by the EPA and FWS and may include mitigation of remedial action impacts to riparian plant communities that do not meet the USACE definition of a wetland.

The effects on game species at the Naturita site are expected to be minimal. The mule deer is a year-round resident at the Naturita, Uravan, Dry Flats, and Coke Oven sites; however, habitat features such as critical winter range do not occur at or near the sites that could be disturbed during remedial action. Parts of the small prairie dog towns at the Dry Flats disposal and Coke Oven borrow sites could be temporarily disturbed by remedial action activities. A limited amount of waterfowl production occurs along the San Miguel River in the processing site area, but remedial action activities would be expected to have a minimal effect on waterfowl production. The effects on birds of prey at the site would also be expected to be minimal to nonexistent. No large hawks are known to nest in the cottonwood stands that may be affected. The American kestrel and certain species of small owls may nest in these areas and be affected. The Cooper's hawk may nest along Dry Creek, but potential nesting 
sites are well removed from the area of Dry Creek that could be affected by remedial action.

An analysis of possible effects on threatened and endangered species is presented in Attachment 2, Biological Assessment. This analysis indicates that there would be no direct effects on threatened and endangered species and other species of concern except possibly the flannelmouth sucker and roundtail chub. The willow flycatcher was heard calling along the San Miguel River in 1986 but was not observed or heard calling in 1990 through 1994. Surveys for the southwestern willow flycatcher would be conducted during remedial action. If these surveys revealed that the southwestern willow flycatcher nests in riparian areas that may be affected, formal conferencing with the FWS would be initiated, and a mitigation plan would be prepared. One possible mitigation measure would be to limit remedial action activities in the habitat of the southwestern willow flycatcher.

Remedial action activities at the Naturita processing site would take place in the 100-year floodplain of the San Miguel River and would have the potential to directly affect the flannelmouth sucker and roundtail chub through alteration of the San Miguel River. However, negative impacts would be minimized by not performing remedial action in the river, recontouring and revegetating disturbed ground as soon as possible, using erosion control measures such as mulch and berms where needed, and possibly implementing supplemental standards to exclude as much area as possible along the river from cleanup activities. It is anticipated that implementation of these measures would result in little, if any, negative impact to these fish. In addition, the removal of contaminated materials that pose a potential ecological risk to the terrestrial and aquatic ecosystems may have a positive impact on the species, along with other species in the terrestrial and aquatic ecosystems.

Using water from the San Miguel River for either the Dry Flats or Uravan disposal alternative would cause a net depletion of water in the upper Colorado River basin, which would result in a "may affect" determination for the Colorado squawfish, humpback chub, bonytail chub, and razorback sucker. This net depletion of water would also adversely affect critical habitat of these species. These determinations would require formal conferencing with the FWS, which would likely result in the payment of a dollar amount per acre-foot of water used for remedial action. The average annual water withdrawal for the Dry Flats disposal alternative is estimated to be 86 acre-feet.

At the Uravan site, compliance with the applicable regulations for the protection of wetlands and threatened and endangered species would be the responsibility of the owner and operator of the Uravan site. If County Road EE-22 were improved for the transportation of the Naturita RRM to the Uravan site, the DOE would comply with the applicable regulations for the protection of wetlands and threatened and endangered species. 


\subsection{HISTORICAL AND CULTURAL RESOURCES}

The BLM has evaluated the potential for historical resources (e.g., buildings and their contents) at the Naturita processing site, and certain features at the site have been recommended as eligible for nomination to the NRHP (Kesterke, 1993). The DOE consulted with the SHPO, who declared the Naturita processing site (former Vanadium Corporation of America mill site) eligible for listing in the NRHP (Hartmann, 1994). The proposed remedial action includes the demolition of the structures at the processing site. This action would adversely affect the NRHP-eligible structures. The DOE will have the appropriate Historic American Engineering Record documentation completed for the NRHP-eligible structures and the overall processing site.

The Office of Historic Preservation for the state of Colorado has indicated that the only site within $50 \mathrm{mi}(80 \mathrm{~km})$ of the Uravan facility nominated for the National Register of Historic Places is the Hanging Flume, approximately $5 \mathrm{mi}$ $(8 \mathrm{~km})$ northwest of the facility along Colorado State Highway 141 . This site is not affected by the Uravan facility's operations. An effort to save several buildings associated with the mill site has been made by the Rimrock Historical Society, and discussions among the mill owner/operator, the historical society, and the state are under way. These buildings are not affected by the disposal of Naturita RRM at the disposal facility, located approximately $400 \mathrm{ft}(122 \mathrm{~m})$ above the former town site.

Cultural resources at the Naturita processing site, Dry Flats disposal site, and Coke Oven borrow site could be affected by remedial action activities. Prior to any surface-disturbing activities at any of the sites, the DOE would compile the results of all of the cultural resource surveys and prepare an evaluation of the cultural resource sites that could be affected by remedial action. This evaluation would include NRHP-eligibility determinations and mitigative measures (e.g., avoidance or data recovery plans) for the cultural resource sites that could be affected. The evaluation would be submitted to the BLM and SHPO for concurrence, and any data recovery plans deemed necessary would be implemented in accordance with the requirements of the National Historical Preservation Act. If required by the BLM and SHPO, a qualified archaeologist would monitor all surface-disturbing activities to detect any cultural resources that were not located during the cultural resource surveys.

\subsection{LAND USE}

During either the Uravan or Dry Flats disposal alternative, approximately 133 ac ( 55 ha) would be disturbed within and adjacent to the designated Naturita processing site. Almost all of this acreage is privately owned land that is not currently being used. The BLM-administered land in the former ore storage area would be disturbed during the remedial action, but the BLM-administered land west of Colorado State Highway 141 (Area D in Figure 4.1) would not be disturbed by remedial action due to the application of supplemental standards. Both of these areas have steep slopes and probably do not receive much if any 
of the grazing in the Sawtooth grazing allotment (Sazama, 1993) or any oil and gas exploration and development (Lewis, 1993). Therefore, the remedial action would not affect the grazing capacity of the Sawtooth grazing allotment or the active oil and gas leases that contain these BLM-administered lands. After remedial action, all of the disturbed areas would be backfilled, recontoured to promote surface drainage, revegetated, and eventually released for any use consistent with existing land use controls. However, certain use restrictions may be imposed at the federal and state levels to protect human health and the environment and to prevent the use of potentially contaminated ground water at the processing site. Certain use restrictions may also be imposed at the federal and state levels to allow future cleanup and/or control of existing ground water contamination beneath the processing site during the ground water restoration phase of the UMTRA Project.

With the Dry Flats disposal alternative, approximately 84.5 ac (34.2 ha) would be disturbed at the Dry Flats disposal site for the construction of the disposal cell. This would result in the temporary loss of 4 percent of the 2387-ac 1966ha) Lillylands-West grazing allotment, which is permitted for 224 AUMs per year. This acreage loss would represent a temporary loss of 15 to 16 AUMs per year for almost 3 years of remedial action. Construction of the disposal cell would also result in the loss of the two livestock water tanks at the disposal site. After the remedial action, the final restricted disposal site would encompass 57 ac (23 ha), and any future use of this area would be precluded. This would result in a permanent loss of 2 percent of the Lillylands-West grazing allotment, which would represent a permanent loss of 7 AUMs per grazing year (Sazama, 1993). The DOE would mitigate both the temporary and permanent losses of grazing forage and the livestock water tanks according to the terms of a land use agreement negotiated between the DOE and the grazing lessee.

The improvement of County Road GG-25 for the Dry Flats disposal alternative would disturb approximately 7 ac ( 3 ha) that is not already covered by the road [ 3 ac (1 ha)]. The improved road would remain intact after the remedial action as requested by the Montrose County Road Commission. This would represent a permanent loss of approximately 1 AUM per grazing-year in the LillylandsWest and Coke Oven grazing allotments. The improvement of County Road GG-25 would not have any effect on the grazing capacity of the East Paradox grazing allotment, because the portion of the grazing allotment that is crossed by the road is not grazed or is grazed very infrequently (Sazama, 1994). Construction of the new haul road from County Road GG-25 to the Dry Flats disposal site would-disturb approximately 1 ac $(0.4 \mathrm{ha})$. After the remedial action, this haul road would be reduced to minimum BLM standards le.g., $16 \mathrm{ft}$ $(5 \mathrm{~m})$ wide], and the excess road width [approximately 0.5 ac $(0.2$ ha)] would be reclaimed in accordance with the ROW issued by the BLM. With the permanent loss of the disposal site and road acreage lapproximately 64.5 ac $(26.1$ ha) $)$, a total of 8 AUMs per grazing year would be permanently lost in the Lillylands-West and Coke Ovens grazing allotments. These grazing allotments are permitted for a total of 448 AUMs per grazing year. During each year of remedial action, 2 to 3 AUMs in these grazing allotments would be temporarily 
lost along the road to the disposal site (Sazama, 1993). The DOE would mitigate both the temporary and permanent losses of grazing forage in accordance with land use agreements negotiated between the DOE and the grazing lessees and the owner of the private land that is crossed by County Road GG-25.

A maximum of 135 ac ( 55 ha) would be temporarily disturbed at the Coke Oven borrow site during the Dry Flats disposal alternative. This would result in the temporary loss of 2 percent of the 7660-ac (3100-ha) Coke Ovens grazing allotment, which is permitted for 224 AUMs per year. This acreage loss would represent a temporary loss of 16 to 17 AUMs per year for almost 2 years of the remedial action. The DOE would mitigate the temporary loss of grazing forage in accordance with the land use agreement negotiated between the DOE and the grazing lessee. The land disturbed at the borrow site would be restored according to the terms of the Free Use Permit issued by the BLM and the Mined Land Reclamation Permit issued by the Colorado Department of Natural Resources, Division of Minerals and Geology.

The remedial action activities at the Dry Flats disposal site and the Coke Oven borrow site would not affect the active oil and gas leases at these sites. It is unlikely that any oil and gas exploration or development would occur at or immediately adjacent to the disposal or borrow site. If such activities were proposed, the DOE would negotiate an agreement(s) with the lessee(s) to avoid any interference between the activities and the remedial action. Prior to any surface disturbance at the Coke Oven borrow site, a Free Use Permit would be obtained from the BLM subject to any existing oil and gas leases and the validity of any existing lode mining claims.

The Uravan disposal alternative would preclude the use of the Dry Flats disposal site; consequently, the land use impacts associated with the use of that site would not occur. It is anticipated that earthen materials for restoration of the Naturita processing site would be obtained from existing, privately owned, commercial borrow sites in the vicinity of the processing site. This would preclude the use of the Coke Oven borrow site and the occurrence of the land use impacts associated with that borrow site. Land owners adjacent to the Uravan disposal facility are the BLM and Umetco Minerals Corporation. Land uses surrounding the site include livestock grazing, uranium/vanadium mining, and recreational uses such as hunting and camping. There are no permanent residences within a $5-\mathrm{mi}(8-\mathrm{km})$ radius of the site. Much of the land is held by the BLM and is leased to ranchers for grazing. There are no irrigated farmlands within $5 \mathrm{mi}(8-\mathrm{km})$ of the disposal site because of the lack of an adequate water supply and the general inaccessibility of the area.

If the Coke Oven borrow site were used for the Uravan disposal alternative, approximately $1 \mathrm{mi}(2 \mathrm{~km}$ ) of County Road GG-25 from Colorado State Highway 90 to the borrow site would be improved as it would be for the Dry Flats disposal alternative [e.g., widened to a maximum of $32 \mathrm{ft}(10 \mathrm{~m})$ ]. This improvement would disturb approximately 3 ac ( 1 ha) not already covered by 
the road [1 ac ( $0.5 \mathrm{ha})]$, and the improved road would remain intact as requested by the Montrose County Road Commission. Therefore, this improvement of County Road GG-25 would have similar but considerably fewer land use impacts than the Dry Flats disposal alternative. The improvement of County Road GG-25 and the use of the Coke Oven borrow site for the Uravan disposal alternative would be subject to the same types of ROW. Free Use Permit, and land use agreements that would be required for the Dry Flats disposal alternative.

The proposed remedial action includes implementing supplemental standards for the contamination on approximately 112 ac (45 ha) of BLM-administered land adjacent to the Naturita processing site and west of Colorado State Highway 141 (Area $D$ in Figure 4.1). If the application for supplemental standards were approved, this contamination would not be cleaned up. An application for supplemental standards is based on and includes a radiological and engineering assessment (REA) of the property involved. The REA would be provided to the owner(s) of the involved property, and owner comments would be included in the REA. The NRC and state of Colorado must concur in the REA and application for supplemental standards before the supplemental standards could be implemented. After the remedial action was complete, the property would be certified as meeting the EPA standards, and the public land records for the property would be annotated with the action taken. Annotation of the public land records could involve the attachment of land use restrictions to prevent or minimize future hazards. For example, annotation of the public land records for Area $D$ at the Naturita site might include the recommendation that surface disturbance such as excavation be prohibited in the area.

\subsection{SOCIOECONOMICS}

There would be an average of 54 workers and a maximum of 76 workers during the 36 months of the Dry Flats disposal alternative. The majority of the remedial action consists of earthmoving, so the labor categories in highest demand would be truck drivers and heavy equipment operators. The most truck drivers and heavy equipment operators would be required during relocation of the RRM and placement of the radon barrier and frost protection layer. An estimated maximum of 36 truck drivers and 16 heavy equipment operators would be needed for approximately 10 months of the remedial action.

Experience at other Colorado UMTRA Project sites indicates that 60 to 90 percent of the remedial action workers (an average of 32 to 49 workers for the Dry Flats disposal alternative) are hired from within a 60-mi $(97-\mathrm{km})$ commuting radius of a site (DOE, $1993 \mathrm{~b}$ ). If an adequate labor force was not locally available, remedial action workers might commute daily from nearby communities or less frequently from farther communities such as Montrose and Grand Junction. The remedial action would not be expected to appreciably reduce unemployment in the Naturita-Nucla area. The labor needs for the remedial action would be relatively small and the employment period would be 
relatively short, which would preclude a large influx of permanent workers into the Naturita-Nucla area.

Secondary employment may be generated when money spent on the remedial action is respent and the new expenditures create a demand for new jobs. Secondary employment generally occurs in the services sector. Experience indicates that the Naturita-Nucla area would have an average secondary employment multiplier of 1.8 (i.e., for each remedial action job, 0.8 of a new job would be created) (DOE, 1993b). However, due to the relatively short remedial action period, it is unlikely that any appreciable indirect employment would be created.

A certain number of workers, primarily contractor management personnel, would be expected to relocate to the Naturita-Nucla area for the remedial action. Typically, 15 to 20 management personnel would be expected to relocate during the 36-month remedial action. Some workers with specialized skills (e.g., health physicists) who may not be locally available would be expected to temporarily relocate for shorter time periods. In addition, other workers may temporarily relocate into the area if sufficient workers are not locally available. Workers who temporarily relocate to work on construction projects such as the Naturita remedial action generally do not bring their families with them.

Due to the shortage of available housing in the Naturita-Nucla area, an influx of remedial action workers could create a strain on local housing, especially during peak construction periods. It is anticipated that most, if not all, of the remedial action housing requirements could be satisfied by filling vacancies at trailer and recreational vehicle parks in Naturita and Nucla (Latta, 1993; Crane, 1993). Motels in Naturita could also provide housing for workers. If sufficient housing could not be found in the Naturita-Nucla area, it is anticipated that remedial action workers would commute daily or less frequently from farther communities.

Due to the small number of workers expected to relocate into the Naturita-Nucla area, it is unlikely that the remedial action would have an appreciable adverse effect on community services and facilities. Most of the workers would not be expected to bring families with them, and the maximum effects would occur during peak construction periods that would be of short duration. It is believed that local community services such as utilities and police protection are adequate to accommodate a small, temporary influx of workers (Latta, 1993). The Naturita Middle School and Nucla Elementary School could accommodate a maximum of 65 additional students without providing additional facilities and personnel. Depending on the number and grades of additional high school students, the Nucla High School might have to hire at least one part-time teacher (Hopewell, 1993; Mahaney, 1993; Harrison and Kelly, 1993).

The remedial action would have direct, positive effects on the economies of the Naturita-Nucla area and Montrose County due to wages and salaries paid to remedial action workers and expenditures for equipment, materials, and 
supplies. There would also be secondary, positive benefits to the local economies as the monies from these wages, salaries, and local purchases are recirculated. Direct and secondary expenditures by contractors to the DOE would generate tax revenues that would be available for county and state government use.

The Dry Flats disposal alternative would cost an estimated $\$ 9.8$ million, which includes the costs of labor, equipment purchases and leases, materials and supplies, and miscellaneous purchases. Wages and salaries would total approximately $\$ 3.9$ million. It is assumed that all of the labor and supplies and one-half of the equipment would be available within Montrose County and that the remainder of the equipment would be available elsewhere in the state of Colorado. The cost of the equipment acquired outside of Montrose County is estimated to be $\$ 600,000$. In addition to local, direct expenditures, revenue would be indirectly generated from remedial action money recirculating throughout the economy. Secondary earnings multipliers for similar projects generally range from 1.3 to 1.6 , and earnings multipliers used in previous UMTRA Project studies in Colorado have ranged from 1.5 to 1.7 , depending on the site location. Using an indirect earnings multiplier of 1.66 for the NaturitaNucla area (DOE, 1993b), the Dry Flats disposal alternative would generate approximately $\$ 3.9$ million in direct earnings and $\$ 2.6$ million in indirect earnings.

During the Uravan disposal alternative, the disposal at the Uravan site could be performed by existing employees of that facility. The remedial action at the Naturita processing site and the transportation of the RRM to the Uravan site would be the responsibility of the DOE. Therefore, it is anticipated that the Uravan disposal alternative would require fewer workers than the Dry Flats disposal alternative, even though some additional employees may have to be hired at the Uravan site. This could minimize the influx of workers into the Naturita-Nucla area and the corresponding impacts on housing, community services, and community facilities. As with the Dry Flats disposal alternative, the Uravan disposal alternative would not be expected to appreciably reduce unemployment or create indirect employment in the Naturita-Nucla area.

The cost of the Uravan disposal alternative is not known at this time. However, as with the Dry Flats disposal alternative, the majority of the direct, positive economic effects due to wages and salaries, local purchases, the recirculation of monies, and tax revenues would occur in the Naturita-Nucla area and Montrose County.

\subsection{TRANSPORTATION}

The existing levels of traffic on local highways are low, so the Uravan disposal alternative would result in an appreciable increase in local highway traffic. However, this increase in traffic would be limited in duration due to the shortterm remedial action schedule. The largest number of highway truck trips would still be associated with the transportation of the RRM from the processing site 
to the Uravan site. This would result in an appreciable increase in local highway traffic. It is anticipated that the transportation of the RRM would occur on Colorado State Highway 141, and, as with the Dry Flats disposal alternative, this activity would take an estimated maximum of 300 truck trips per day. This amount of truck traffic would approach or slightly exceed the projected 1994 average daily traffic for this highway and the capacity of this highway at level of service "A." If County Road EE-22 were used for the transportation of the Naturita RRM, the amount of remedial action truck traffic would be reduced on a portion of Colorado State Highway 141. However, it is anticipated that the amount of truck traffic on Colorado State Highway 141 would still approach or slightly exceed the projected 1994 average daily traffic for this highway and the capacity of this highway at level of service "A."

For the Dry Flats alternative, the largest number of highway truck trips would be associated with the transportation of the Naturita RRM from the processing site to the Dry Flats disposal site, a distance of $0.8 \mathrm{mi}(1.3 \mathrm{~km})$ on Colorado State Highway 141 and $2.4 \mathrm{mi}(3.9 \mathrm{~km})$ on Colorado State Highway 90 . This activity would take approximately 12 months and would result in an estimated maximum of 300 truck trips per day on State Highways 141 and 90 . This amount of truck traffic would approach or slightly exceed the projected 1994 average daily traffic for these highways and could approach or slightly exceed the capacities of these highways at level of service "A."

The levels of traffic on Colorado State Highways 90 and 141 are low; therefore, there are no traffic accident statistics that would apply in evaluating accidents due to traffic generated by the proposed remedial action. The UMTRA Project's accident rates for both highway and on-site accidents are well below any accident projections for similar projects. Therefore, the number of traffic accidents due to the remedial action would be expected to be well below that recorded for the lightly traveled state highways that could be used.

The CDOT was consulted regarding mitigative measures for the use of Colorado State Highways 90 and 141 during the Uravan or Dry Flats disposal alternatives. The RAC would limit haulage to 10 hours per day, 5 days per week, unless weather or other delays necessitated weekend work to maintain the remedial action schedule. Trained personnel would be used to control traffic at the processing site to avoid traffic delays in excess of 15 minutes. In addition, a rubber mat would be used to cross haul trucks from the former ore storage area to the processing site to avoid the possible contamination of Colorado State Highway 141. The CDOT would evaluate the need for mitigative measures at the intersection of Colorado State Highways 90 and 141 in response to the anticipated increase in truck traffic due to the remedial action. The RAC would consult with the CDOT throughout the remedial action to determine any necessary mitigative measures for increased traffic due to the remedial action. The transportation of all contaminated materials and borrow materials would be performed in accordance with all applicable DOT and CDOT permits and regulations and any MOUs or other agreements between the DOE, DOT, and CDOT. 
The use of county roads and state highways during the remedial action would affect the conditions of these roads, and some road maintenance could be necessary. County roads used during the remedial action would be maintained by the RAC unless other arrangements were made with the appropriate state or county agencies. The maintenance of any state highways used during the remedial action would be performed by the CDOT under the provisions of a road maintenance agreement between the DOE, CDPHE, and CDOT. These agreements would provide for monetary compensation from the DOE for maintenance of the sections of any state highways affected by the remedial action.

The transportation of contaminated materials and borrow materials between the sites involved in the remedial action would result in increased noise levels along the transportation routes. However, this impact would be temporary (for a maximum of approximately 12 months) and would be limited to weekdays. Noise levels in Colorado are controlled by city, county, state, and federal noise regulations, and the DOE would comply with all applicable noise regulations. 


\subsection{MITIGATIVE MEASURES}

The following mitigative measures were incorporated into the design and approach for the proposed remedial action to reduce the environmental impacts. The various permits required for the remedial action would contain specific mitigative measures to satisfy permit requirements. For example, the Free Use Permit issued by the BLM would identify specific reclamation requirements for the Coke Oven borrow site.

- An Air Pollution Emissions Notice and Emission Permit would be obtained from the state of Colorado prior to beginning the remedial action. This permit would require implementation of a dust control plan that would include measures such as covering haul trucks, treating haul roads, limiting speeds on unpaved haul roads, and stopping work during windy periods. A monitoring plan to ensure that air quality standards are not exceeded would be developed by the RAC and must be approved by the state of Colorado and Montrose County before any ground-disturbing activities are initiated. If the Naturita RRM were removed to the Uravan site, compliance with the applicable air quality standards at the Uravan site would be the responsibility of the owner and operator of the site.

- To prevent off-site contamination during the transportation of contaminated materials, all haul trucks would be monitored and decontaminated prior to entering public roads. All traveled areas would have scheduled monitoring for radioactive contaminants.

- The DOE would mitigate impacts to wetlands as determined by the USACE Section 404 Permit process. This permit process may include mitigation of remedial action impacts to riparian habitat that does not meet the USACE definition of a wetland. Compliance with the applicable regulations for the protection of wetlands at the Uravan site would be the responsibility of the owner and operator of the site.

- All disturbed areas would be reclaimed as soon as possible in accordance with applicable land use authorizations and agreements. Reclamation may include revegetation with plants native to the area and restrictions on grazing use of the reclaimed areas (e.g., fencing) until revegetation is established.

- The DOE would mitigate the temporary and permanent losses of grazing forage and livestock water sources in accordance with land use agreements negotiated with affected grazing lessees and land owners.

- Haul trucks would not travel Colorado State Highways 90 and 141 on weekends and holidays unless weather or other delays necessitated additional work to maintain the remedial action schedule. Trained personnel would control traffic at the processing site to avoid traffic delays.

- The DOE will perform recordation of the Naturita uranium processing site in accordance with the Historic American Engineering Record guidelines as directed by the National Park Service and the SHPO. 
- Cultural resource sites would be avoided whenever possible. If cultural resource sites could not be avoided, the DOE would develop and implement data recovery plans for the cultural resources in consultation with the BLM and SHPO. If necessary, a qualified archaeologist would monitor all surface-disturbing activities to detect cultural resources. Compliance with the applicable regulations for the protection of historical and cultural resources at the Uravan site would be the responsibility of the owner and operator of the Uravan site. 


\subsection{CONSULTATION AND COORDINATION}

The following federal, state, and local agencies, organizations, and individuals have been instrumental in providing information and assessing UMTRA Project impacts on their resources.

Name Contribution

Bureau of Land Management, U.S. Department of the Interior Montrose District and Uncompahgre Basin Resource Area

Alan Belt

Mike Blymer

Robert Carruthers

Rich Fike

Tom Hurshman

Lynn Lewis

Dennis Murphy

Teresa Pfifer

Jim Sazama

Bob Welch
Land use

Threatened and endangered species

Threatened and endangered species

Cultural resources

Land use

Geology and minerals

Soils

Land use

Land use

Flora and fauna and threatened and endangered species

Colorado Department of Employment and Training

Dave Larson

Socioeconomics

Colorado Department of Local Affairs, Division of Local Government

Reid Reynolds

Socioeconomics

Colorado Department of Transportation

Shirley Gilmore

Transportation

Colorado Division of Highways

Roger Gilpin

Larry Meyers

Colorado Division of Wildlife, Colorado Department of Natural Resources

Tom Nesler

Rick Sherman

Threatened and endangered species

Threatened and endangered species
Transportation

Transportation

\section{Colorado Natural Areas Program}

Steve O'Kane Flora and fauna 


Name Contribution

Colorado Natural Heritage Inventory

R. Voight

Flora and fauna

Colorado State Highway Department, Region 5

Dick Langoni Transportation

Montrose County, Land Use Department

Pat Warren Land use

Montrose County Sheriff

Margie Thomson Socioeconomics

Helen Vodopich Socioeconomics

Montrose Job Service

Dan Holiday Socioeconomics

Montrose Memorial Hospital

Kathy Holman Socioeconomics

Montrose West Recreation

John Showalter Land use

Naturita Basin Clinic

Ann Kettle Socioeconomics

State of Colorado, Council of Governments, Region 10

Colleen Hannon Land use 


Name Contribution

Town of Naturita

$\begin{array}{ll}\text { Carolyn Bean } & \text { Land use } \\ \text { Dan Crane } & \text { Socioeconomics } \\ \text { Karen Hall } & \text { Socioeconomics } \\ \text { Marcell Hopkins } & \text { Socioeconomics } \\ \text { Roberta Latta } & \text { Socioeconomics } \\ \text { Leslie Trachsler } & \text { Water use }\end{array}$

\section{U.S. Army Corps of Engineers}

Ken Jacobsen Wetlands

\section{U.S. Fish and Wildlife Service, U.S. Department of the Interior}

John Anderson

LeRoy Carlson

Bob Leachman

Jeffrey Opdycke

Keith Rose

West End School District

Phyllis Harrison

Wayne Hopewell

Shelley Kelly

Constance Mahaney
Threatened and endangered species

Threatened and endangered species

Threatened and endangered species

Threatened and endangered species

Threatened and endangered species
Socioeconomics
Socioeconomics
Socioeconomics
Socioeconomics

The DOE will continue to consult and coordinate with the appropriate agencies and organizations regarding the remedial action at the Naturita site. In addition, the DOE will maintain close communication with involved agencies and organizations and the general public through an established public information program. 


\subsection{REFERENCES}

BFEC (Bendix Field Engineering Corp.), 1985. "Radiologic Characterization of the Naturita, Colorado, Uranium Tailings Remedial Action Site," GJ-32 (85), prepared for the U.S. Department of Energy, Assistant Secretary for Nuclear Energy, Grand Junction Area Office, Colorado.

BLM (Bureau of Land Management), 1985. Record of Decision for San Juan-San Miguel Resource Management Plan and Final Environmental Impact Statement, U.S. Department of the Interior, Bureau of Land Management, Montrose District, Colorado, San Juan Resource Area and Uncompahgre Basin Resource Area.

CAOCC (Colorado Air Quality Control Commission), 1979. "Ambient Air Standards for Metropolitan Denver Air Quality Control Region, State Air Pollution Control Areas and the State of Colorado," Colorado Air Quality Control Commission, Denver, Colorado.

CASA (Complete Archaeological Service Associates), 1993a. "Cultural Resource Planning Inventory, Windblown Contamination Supplemental Standards Area, Naturita UMTRA Project, Montrose County, Colorado," CASA 93-60, prepared by CASA, Cortez, Colorado, for Jacobs Engineering Group Inc., Albuquerque, New Mexico.

CASA (Complete Archaeological Service Associates), 1993b. "Cultural Resource Inventory and Evaluation Testing, Coke Oven Borrow Area, Naturita UMTRA Project, Montrose County, Colorado," Archaeological Report 93-48, prepared by CASA, Cortez, Colorado, for Jacobs Engineering Group Inc., Albuquerque, New Mexico.

CASA (Complete Archaeological Service Associates), 1990a. "Cultural Resource Planning Inventory, Naturita UMTRA Project, Dry Flats Disposal Site and Coke Oven Borrow Area, Montrose County, Colorado," Archaeological Report 90-12, prepared by CASA, Cortez, Colorado, for Jacobs Engineering Group Inc., Albuquerque, New Mexico.

CASA (Complete Archaeological Service Associates), 1990b. "Cultural Resource Planning Inventory, Naturita UMTRA Project, Expanded Coke Oven Borrow Area, Montrose County, Colorado," Archaeological Report 90-71, prepared by CASA, Cortez, Colorado, for MK-Ferguson Company, Albuquerque, New Mexico.

CASA (Complete Archaeological Service Associates), 1989a. "Cultural Resource Inventory, Naturita UMTRA Project, Montrose County, Colorado," Archaeological Report 89-25, prepared by CASA, Cortez, Colorado, for Jacobs Engineering Group Inc., Albuquerque, New Mexico. 
CASA (Complete Archaeological Service Associates), 1989b. "Cultural Resource Inventory, 33 Test Pit Locations, Coke Oven Borrow Site and Dry Flats Disposal Site, Naturita UMTRA Project, Montrose County, Colorado," Archaeological Report 89-37, prepared by CASA, Cortez, Colorado, for Jacobs Engineering Group Inc., Albuquerque, New Mexico.

CDPHE (Colorado Department of Public Health and Environment), 1985. "Colorado Air Quality Data Report 1985," State of Colorado, Department of Public Health and Environment, Denver, Colorado.

Crane, Dan, 1993. UMTRA Project Naturita Citizens Advisory Committee, Naturita, Colorado, personal communication to Dale Jones, Jacobs Engineering Group Inc., Albuquerque, New Mexico, October 4, 1993.

Dames \& Moore, 1978. Environmental Report - Uravan Uranium Project.

DOC (U.S. Department of Commerce), 1991a. 1990 Census of Population and Housing: Summary Population and Housing Characteristics, Colorado, U.S. Department of Commerce, Economics and Statistics Administration, Bureau of the Census.

DOC (U.S. Department of Commerce), 1991b. 1990 Census of Population: General Population Characteristics, Colorado, U.S. Department of Commerce, Economics and Statistics Administration, Bureau of the Census.

DOC (U.S. Department of Commerce), 1991c. 1990 Census of Population and Housing: Summary Social, Economic, and Housing Characteristics, Colorado, U.S. Department of Commerce, Economics and Statistics Administration, Bureau of the Census.

DOC (U.S. Department of Commerce), 1991d. 1990 Census of Population and Housing: General Housing Characteristics, Colorado, U.S. Department of Commerce, Economics and Statistics Administration, Bureau of the Census.

DOE (U.S. Department of Energy), 1993a. "Remedial Action Plan and Site Design for Stabilization of the Inactive Uranium Mill Tailings Site at Naturita, Colorado," preliminary final, DOE/AL/62350-40PF, DOE UMTRA Project Office, Albuquerque Operations Office, Albuquerque, New Mexico.

DOE (U.S. Department of Energy), 1993b. Final Colorado Economic Impact Study on the Uranium Mill Tailings Remedial Action Project in Colorado, UMTRA-DOE/AL400691.0000, DOE UMTRA Project Office, Albuquerque Operations Office, Albuquerque, New Mexico.

DOE (U.S. Department of Energy), 1988a. Comparative Analysis of Disposal Site Alternatives Report for the UMTRA Project Naturita Site Located at Naturita, Colorado, November 1988, DOE UMTRA Project Office, Albuquerque Operations Office, Albuquerque, New Mexico. 
DOE (U.S. Department of Energy), 1988b. Technical Approach Document, Revision 1, UMTRA-DOE/AL-050425.0000, DOE UMTRA Project Office, Albuquerque Operations Office, Albuquerque, New Mexico.

DOE (U.S. Department of Energy), 1986. "Comparative Analysis of Disposal Site Alternatives Report for the UMTRA Project Naturita Site Located at Naturita, Colorado," draft, DOE UMTRA Project Office, Albuquerque Operations Office, Albuquerque, New Mexico.

DOE (U.S. Department of Energy), 1985. Programmatic Environmental Report for Remedial Actions at the UMTRA Project Vicinity Properties, UMTRA-DOE/AL150327.0000, DOE UMTRA Project Office, Albuquerque Operations Office, Albuquerque, New Mexico.

FBDU (Ford, Bacon \& Davis Utah Inc.), 1981. Engineering Assessment of Inactive Uranium Mill Tailings, Naturita Site, Naturita, Colorado, DOENMT-012, FBDU 360-08, UC-70, prepared by FBDU, Salt Lake City, Utah, for the U.S. Department of Energy, UMTRA Project Office, Albuquerque Operations Office, Albuquerque, New Mexico.

Fike, Richard, 1993. Montrose District, Bureau of Land Management, Montrose Colorado, personal communication to Dale Jones, Jacobs Engineering Group Inc., Albuquerque, New Mexico, June 9, 1993.

Hall, Karen, 1993. Ray Motel, Naturita, Colorado, personal communication to Dale Jones, Jacobs Engineering Group Inc., Albuquerque, New Mexico, October 4, 1993.

Harrison, Phyllis, and Shelley Kelly, 1993. Nucla High School, Nucla, Colorado, personal communication to Dale Jones, Jacobs Engineering Group Inc., Albuquerque, New Mexico, October 5, 1993.

Hartmann, James E. 1994. State Historic Preservation Officer, Colorado Historical Society, Denver, Colorado, personal communication to L. A. Woodworth, U.S. Department of Energy, UMTRA Project Office, Albuquerque Operations Office, Albuquerque, New Mexico, May 6, 1994.

Holiday, Dan, 1993. Montrose Job Service, Montrose, Colorado, personal communication to Linda Ulland, Jacobs Engineering Group Inc., Albuquerque, New Mexico, September 16, 1993.

Holman, Kathy, 1993. Montrose Memorial Hospital, Montrose, Colorado, personal communication to Malu Gawthrop-Cooper, Jacobs Engineering Group Inc., Albuquerque, New Mexico, September 16, 1993.

Hopewell, Wayne, 1993. Naturita Middle School, Naturita, Colorado, personal communication to Dale Jones, Jacobs Engineering Group Inc., Albuquerque, New Mexico, October 5, 1993. 
Hopkins, Marcell, 1993. Bunkhouse Motel, Naturita, Colorado, personal communication to Dale Jones, Jacobs Engineering Group Inc., Albuquerque, New Mexico, October 4, 1993.

International Engineering Co., Inc., 1981. Uravan Tailings Reclamation Report.

Jacobsen, Ken, 1992. U.S. Army Corps of Engineers, Grand Junction, Colorado, personal communication to Charles Burt, Jacobs Engineering Group Inc., Albuquerque, New Mexico, October 5, 1992.

Jackson, William L., and Randall P. Julander, 1982. "Runoff and Water Quality from Three Soil Landform Units on Mancos Shale," in Water Resources Bulletin, Vol. 18 , No. 6, by American Water Resources Association.

Kesterke, Alan, 1993. Montrose District, Bureau of Land Management, Montrose, Colorado, personal communication to Mike Abrams, U.S. Department of Energy, UMTRA Project Office, Albuquerque Operations Office, Albuquerque, New Mexico, September 10, 1993.

Kettle, Ann, 1993. Naturita Basin Clinic, Naturita, Colorado, personal communication to Malu Gawthrop-Cooper, Jacobs Engineering Group Inc., Albuquerque, New Mexico, September 16, 1993.

Langoni, Richard, 1993. Colorado Department of Transportation, Region 5-Engineering, Durango, Colorado, personal communication to Dale Jones, Jacobs Engineering Group Inc., Albuquerque, New Mexico, June 18, 1993.

Larson, Dave, 1993. Labor Information Division, Colorado Department of Employment and Training, Denver, Colorado, personal communication to Linda Ulland, Jacobs Engineering Group Inc., Albuquerque, New Mexico, September 15, 1993.

Latta, Roberta, 1993. Hometown Realty, Naturita, Colorado, personal communication to Dale Jones, Jacobs Engineering Group Inc., Albuquerque, New Mexico, September 23, 1993.

Lewis, Lynn, 1993. Uncompahgre Basin Resource Area, Bureau of Land Management, Montrose, Colorado, personal communication to Dale Jones, Jacobs Engineering Group Inc., Albuquerque, New Mexico, June 10, 1993.

Mahaney, Constance, 1993. Nucla Elementary School, Nucla, Colorado, personal communication to Dale Jones, Jacobs Engineering Group Inc., Albuquerque, New Mexico, October 5, 1993.

NAS (National Academy of Sciences), 1980. The Effects on Population of Exposure to Low Levels of Ionizing Radiation, BEIR-III Report, Advisory Committee on Biological Effects of lonizing Radiation, National Research Council, Washington, D.C. 
NGDC/NOAA (National Geophysical Data Center for National Oceanic and Atmospheric Administration), 1989. Dry Flats Site: Epicentral Compilation for Magnitude $M \geq 4$ and Intensity $\mid \geq 1$, Boulder, Colorado.

NOAA (National Oceanic and Atmospheric Administration), 1986. "Annual Climatological Summary for the Years 1976 through 1985, Paradox, Colorado," National Geophysical Data Center, Asheville, North Carolina.

NOAA (National Oceanic and Atmospheric Administration), 1984. "Climatography of the United States No. 20, Montrose, Colorado, for the Period 1951-1980," National Geophysical Data Center, Asheville, North Carolina.

O'Kane, Steve L., 1987. Colorado Natural Areas Program, Denver, Colorado, personal communication to Eloise Mulford, Jacobs Engineering Group Inc., Albuquerque, New Mexico, February 19 and 21, 1987.

O'Kane, Steve L., 1986. Colorado Natural Areas Program, Denver, Colorado, personal communication to Charles Burt, Jacobs Engineering Group Inc., Albuquerque, New Mexico, February 6, 1986.

ORNL (Oak Ridge National Laboratory), 1980. Radiological Survey of Inactive Uranium-Mill Tailings at Naturita, Colorado, ORNL-5454, Oak Ridge National Laboratory, Oak Ridge, Tennessee.

Pfifer, Teresa, 1993. Uncompahgre Basin Resource Area, Bureau of Land Management, Montrose, Colorado, personal communication to Dale Jones, Jacobs Engineering Group Inc., Albuquerque, New Mexico, May 14, 1993.

Pioneer (Pioneer-Uravan, Inc.), 1979. "Environmental Report, San Miguel Mill Project, San Miguel County, Colorado," prepared by Dames and Moore, Denver, Colorado, for Pioneer-Uravan, Inc., available in the DOE UMTRA Project Office, Albuquerque Operations Office, Document Control File No. 11.19.3, Albuquerque, New Mexico.

Reynolds, Reid, 1993. Colorado Department of Local Affairs, Division of Local Government, Denver, Colorado, personal communication to Linda Ulland, Jacobs Engineering Group Inc., Albuquerque, New Mexico, September 16, 1993.

Sazama, Jim, 1994. Uncompahgre Basin Resource Area, Bureau of Land Management, Montrose, Colorado, personal communication to Dale Jones, Jacobs Engineering Group Inc., Albuquerque, New Mexico, July 19, 1994.

Sazama, Jim, 1993. Uncompahgre Basin Resource Area, Bureau of Land Management, Montrose, Colorado, personal communication to Dale Jones, Jacobs Engineering Group Inc., Albuquerque, New Mexico, June 7 and 17 and July 16, 1993. 
Showalter, Jon, 1993. Montrose West Recreation, Nucla, Colorado, personal communication to Dale Jones, Jacobs Engineering Group Inc., Albuquerque, New Mexico, May 26, 1993.

State of Colorado, 1983. "Appendix I of Consent Decree, Remedial Action Plan," State of Colorado vs. Union Carbide Corporation and Umetco Minerals Corporation, Court Citation 83-C-2384.

TAC (Technical Assistance Contractor), 1990. "Naturita Radon Monitoring Pre-Remedial Action Summary, April 1990," unpublished data and analysis prepared by the TAC for the U.S. Department of Energy, UMTRA Project Office, Albuquerque Operations Office, Albuquerque, New Mexico.

TAC (Technical Assistance Contractor), 1989. "Former Pile Characterization," unpublished data and analysis prepared by the TAC for the U.S. Department of Energy, UMTRA Project Office, Albuquerque Operations Office, Albuquerque, New Mexico.

Thomson, Margie, 1993. Communication Center, Montrose County Sheriff, Naturita, Colorado, personal communication to Rebecca de Neri Zagal, Jacobs Engineering Group Inc., Albuquerque, New Mexico, September 16, 1993.

Trachsler, Leslie, 1989. Town of Naturita, Colorado, personal communication to Kevin Lambert, Jacobs Engineering Group Inc., Albuquerque, New Mexico, November $17,1989$.

USGS (U.S. Geological Survey), 1979. Water Resources Data for Colorado, Water Year 1978, Vol. 3, Dolores River Basin \& Green River Basin, Denver, Colorado.

Vodopich, Helen, 1993. Communication Center, Montrose County Sheriff, Naturita, Colorado, personal communication to Dale Jones, Jacobs Engineering Group Inc., Albuquerque, New Mexico, October 4, 1993.

Voight, R. A., 1984. Colorado Natural Heritage Inventory (Colorado Natural Heritage Program), Denver, Colorado, personal communication to Robert Peel, Jacobs Engineering Group Inc., Albuquerque, New Mexico, September 28, 1984.

Warren, Pat, 1993. Montrose County Land Use Department, Montrose, Colorado, personal communication to Dale Jones, Jacobs Engineering Group Inc., Albuquerque, New Mexico, May 20, 1993.

\section{CODE OF FEDERAL REGULATIONS}

40 CFR Part 50, "National Primary and Secondary Ambient Air Quality Standards," Title 40, Code of Federal Regulations, Part 50, U.S. Environmental Protection Agency, Office of the Federal Register, National Archives and Records Administration, Washington, D.C. 
40 CFR Part 141, "National Interim Primary Drinking Water Regulations," Title 40, Code of Federal Regulations, Part 141, U.S. Environmental Protection Agency, Office of the Federal Register, National Archives and Records Administration,

Washington, D.C.

40 CFR Part 192, "Health and Environmental Protection Standards for Uranium and Thorium Mill Tailings," Title 40, Code of Federal Regulations, Part 192, U.S. Environmental Protection Agency, Office of the Federal Register, National Archives and Records Administration, Washington, D.C.

\section{FEDERAL REGISTER}

52 FR 36000, "Standards for Remedial Actions at Inactive Uranium Processing Sites; Proposed Rule," September 24, 1987, Federal Register, Office of the Federal Register, National Archives and Records Administration, Washington, D.C.

\section{DOE ORDERS}

Order 5400.5, Radiation Protection of the Public and the Environment, February 1990, U.S. Department of Energy, Environmental Protection Division, Washington, D.C.

Order 5480.11, Radiation Protection for Occupational Workers, December 1988, U.S. Department of Energy, Health Protection Division, Washington, D.C. 
ATTACHMENT 1

FLOODPLAINS AND WETLANDS ASSESSMENT 


\section{TABLE OF CONTENTS}

Section

Page

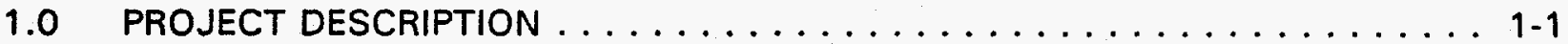

1.1 Introduction ......................... 1-1

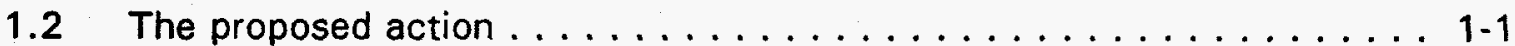

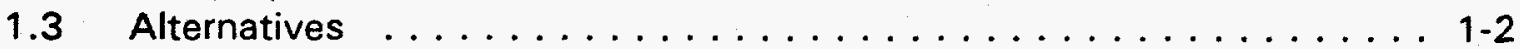

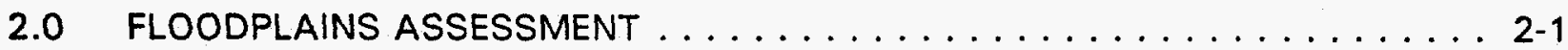

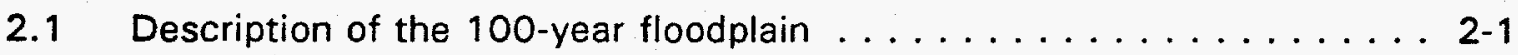

2.2 Floodplain impacts and mitigation ................. 2-1

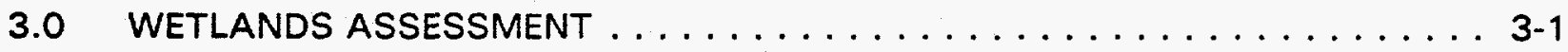

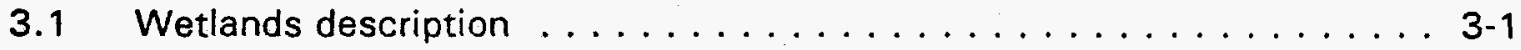

3.2 Wetland impacts and mitigation ................ $3-4$

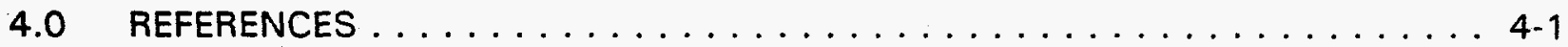




\section{LIST OF FIGURES}

\section{Figure}

Page

2.1 100-year floodplain of the San Miguel River at the Naturita site, Colorado . . . 2-2

3.1 Riparian plant communities at the Naturita site, Colorado . . . . . . . . . 3-2

3.2 Riparian survey along Dry Creek near Naturita, Colorado . . . . . . . . . . . 3-3

\section{LIST OF TABLES}

Table

Page

3.1 Riparian plant communities at the Naturita site, Colorado . . . . . . . 3-5 


\section{LIST OF ACRONYMS AND ABBREVIATIONS}

Acronym

ac

CFR

DOE

EPA

$\mathrm{ft}$

$\mathrm{ft}^{3} / \mathrm{s}$

FWS

ha

$\mathrm{km}$

m

$\mathrm{m}^{3}$

$\mathrm{m}^{3} / \mathrm{s}$

$\mathrm{mi}$

NEPA

NRC

RRM

UMTRCA

USACE

$y d^{3}$

\section{Definition}

acre

Code of Federal Regulations

U.S. Department of Energy

U.S. Environmental Protection Agency

foot

cubic feet per second

Fish and Wildlife Service

hectare

kilometer

meter

cubic meter

cubic meters per second

mile

National Environmental Policy Act of 1969

U.S. Nuclear Regulatory Commission

residual radioactive materials

Uranium Mill Tailings Radiation Control Act of 1978

U.S. Army Corps of Engineers

cubic yard 


\subsection{PROJECT DESCRIPTION}

\subsection{INTRODUCTION}

The Uranium Mill Tailings Radiation Control Act of 1978 (UMTRCA), Public Law 95-604, authorized the U.S. Department of Energy (DOE) to perform remedial action at the Naturita, Colorado, uranium processing site to reduce the potential health effects from the radioactive materials at the site and at vicinity properties associated with the site. The U.S. Environmental Protection Agency (EPA) promulgated standards for remedial actions at inactive uranium processing sites in Title 40, Code of Federal Regulations, Part 192 (40 CFR Part 192). Remedial action at the Naturita site must be performed in accordance with these standards and with the concurrence of the U.S. Nuclear Regulatory Commission (NRC).

In 1979, the DOE established regulations (10 CFR Part 1022) to comply with requirements for the environmental review of floodplains and wetlands. These regulations provide for compliance with Executive Order 11988, Floodplain Management, and Executive Order 11990, Protection of Wetlands, and are designed to be coordinated with the environmental review requirements of the National Environmental Policy Act of 1969 (NEPA). Pursuant to 10 CFR Part 1022 , this assessment describes the impacts of the proposed remedial action on the floodplains and wetlands at the Naturita, Colorado, uranium processing site.

\subsection{THE PROPOSED ACTION}

The designated Naturita uranium processing site encompasses 53 acres (ac) [21 hectares (ha)] on the west bank of the San Miguel River, a perennial tributary of the Dolores River. Contaminated materials cover an estimated 50 ac (20 ha) within the designated site; the contaminated areas are the former tailings area, mill yard, and former ore storage area. An additional 194 ac (79 ha) adjacent to the site have been contaminated by uranium processing activities and wind and water erosion. The estimated volume of residual radioactive materials (RRM) at and adjacent to the Naturita site is 542,400 cubic yards $\left(\mathrm{yd}^{3}\right)$ [414,700 cubic meters $\left.\left(\mathrm{m}^{3}\right)\right]$.

The proposed remedial action for the Naturita processing site is relocation of the RRM to the Uravan disposal site, approximately 13 road miles (mi)

[21 kilometers $(\mathrm{km})]$ to the northwest. At the Uravan disposal site, the RRM would be stabilized and covered with layers of earth and rock. The Uravan site is currently licensed for the disposal of up to 900,000 dry tons $\left(750,000 \mathrm{yd}^{3}\right)$ of Naturita UMTRCA Title I material by the Colorado Department of Public Health and Environment. The remedial action at the processing site would involve the removal of contaminated soils and the disturbance of riparian plant communities within the floodplain of the San Miguel River. After the remedial action, all areas disturbed by the cleanup of the contaminated materials would 
be backfilled with clean fill material, recontoured to promote surface drainage, and revegetated.

An alternate disposal site, Dry Flats, located 6 road $\mathrm{mi}(10 \mathrm{~km})$ to the southeast, has been fully evaluated in this environmental assessment and will serve as a contingency option should legal, technical, or contractual issues preclude the DOE from disposing of the RRM at Uravan. The Dry Flats disposal site is on land administered by the Bureau of Land Management and used primarily for livestock grazing. The final Dry Flats site would cover approximately 57 ac (23 ha), which would be permanently transferred from the BLM to the DOE and restricted from future uses. The remedial action would be conducted by the DOE's UMTRA Project and would be consistent with the EPA standards for inactive (Title I) uranium processing sites.

The remedial action would require the use of earthen materials, gravel, and rock, depending on the disposal site selected by the DOE. Potential sources of earthen materials are existing, privately owned, commercial borrow sites in the vicinity of the processing site and the Coke Oven borrow site. The Coke Oven borrow site is approximately 4 road $\mathrm{mi}(6 \mathrm{~km})$ south of the processing site and approximately 2 road mi $(3 \mathrm{~km})$ west of the Dry Flats disposal site. The sources of gravel and rock are existing, privately owned, commercial quarry sites 22 road $\mathrm{mi}(35 \mathrm{~km})$ northwest of the processing site.

\subsection{ALTERNATIVES}

Stabilization of the RRM in a disposal cell at the designated processing site was evaluated but was found to be technically and environmentally unsuitable. Six other potential disposal sites were also evaluated. Five of these potential sites were found to be technically and environmentally unsuitable and were rejected. None of the remedial action alternatives described above would preclude the need to remove contaminated soils and disturb riparian plant communities within the floodplain of the San Miguel River.

No action at the Naturita processing site would leave the contaminated materials and debris in their present location and condition and would not reduce the potential health effects. The contaminated materials would continue to be exposed to erosion from surface runoff and flood flows from the San Miguel River, and eventual erosion of the contaminated materials could result in the transport of contaminants into the river. The no action alternative would not be consistent with the intent of the UMTRCA and would not result in compliance with the EPA standards.

Supplemental standards are defined in 40 CFR 192.22(a) as "coming as close to meeting the otherwise applicable standards as is reasonable under the circumstances." The bases for applying supplemental standards are limited, long-term health impacts; unlikely human habitation of the area; probable long-term environmental harm; potential risk of injury to workers if remedial action were undertaken; and unrealistically high remedial action costs relative to 
the benefits. The state of Colorado and the NRC must concur in the application of supplemental standards. Some of the contaminated areas at and adjacent to the Naturita site are being considered for exclusion from remedial action by the application of supplemental standards. If supplemental standards were applied to certain areas, the removal of contaminated soils and disturbance of riparian plant communities within the floodplain of the San Miguel River would be reduced. 


\subsection{FLOODPLAINS ASSESSMENT}

\subsection{DESCRIPTION OF THE 100-YEAR FLOODPLAIN}

The principal topographic features affecting the 100-year floodplain at the Naturita site are the high, steep east bank of the San Miguel River and the upper and lower terraces of the mill yard. Water surface profiles for the 100-year flood at the processing site were developed using the U.S. Army Corps of Engineers' (USACE) HEC-2 computer program (USACE, 1982). The peak flow for the 100-year flood was determined to be 10,800 cubic feet per second $\left(\mathrm{ft}^{3} / \mathrm{s}\right)$ [300 cubic meters per second $\left.\left(\mathrm{m}^{3} / \mathrm{s}\right)\right]$ based on peak flows recorded at the U.S. Geological Survey's gaging station on the San Miguel River at Naturita (USGS, 1979). This peak flow would result in maximum water elevations of 5297 feet (ft) [1615 meters (m)] above mean sea level at the mill yard and $5294 \mathrm{ft}(1614 \mathrm{~m})$ above mean sea level at the former tailings pile area. Approximately 31 ac $(13 \mathrm{ha})$ of the mill yard and former tailings area would be inundated to an average maximum depth of $5 \mathrm{ft}(1.5 \mathrm{~m}$ ) (Figure 2.1) (MKE, 1990).

Flooding is not a hazard at the Uravan site. The Naturita RRM disposal area at the Uravan site is approximately $400 \mathrm{ft}(122 \mathrm{~m})$ above the San Miguel River. Flooding is not a hazard at the Dry Flats disposal site or the Coke Oven borrow site. These sites are approximately 1 to 3 air mi $(2$ to $5 \mathrm{~km})$ south of and 200 to $500 \mathrm{ft}(61$ to $152 \mathrm{~m}$ ) above the San Miguel River, the nearest perennial waterway.

The proposed remedial action does not constitute a "critical action" as defined in 10 CFR Part 1022.4(c) and (i); therefore, an analysis of the 500-year floodplain at the Naturita site is not required for this assessment.

\section{$2.2 \quad$ FLOODPLAIN IMPACTS AND MITIGATION}

During the remedial action at the Naturita processing site, approximately 31 ac (13 ha) within the 100-year floodplain would be disturbed with the removal of approximately $263,000 \mathrm{yd}^{3}\left(201,000 \mathrm{~m}^{3}\right)$ of contaminated materials. The average depth of excavation in these areas would be $3 \mathrm{ft}(0.9 \mathrm{~m})$. The removal of contaminated materials from the upper and lower mill yard terraces would. allow the width of the 100-year floodplain to increase slightly, thereby reducing the water depth across the former tailings area. Clean fill material would be backfilled into excavated areas as contaminated materials were removed to minimize any increase in the width of the 100-year floodplain. The remedial action would reduce the radioactive contamination in the 100-year floodplain to levels that comply with the EPA standards.

After completion of the remedial action, the processing site would be restored. All disturbed areas would be recontoured to promote surface drainage and revegetated. The man-made upper and lower mill yard terraces would be 


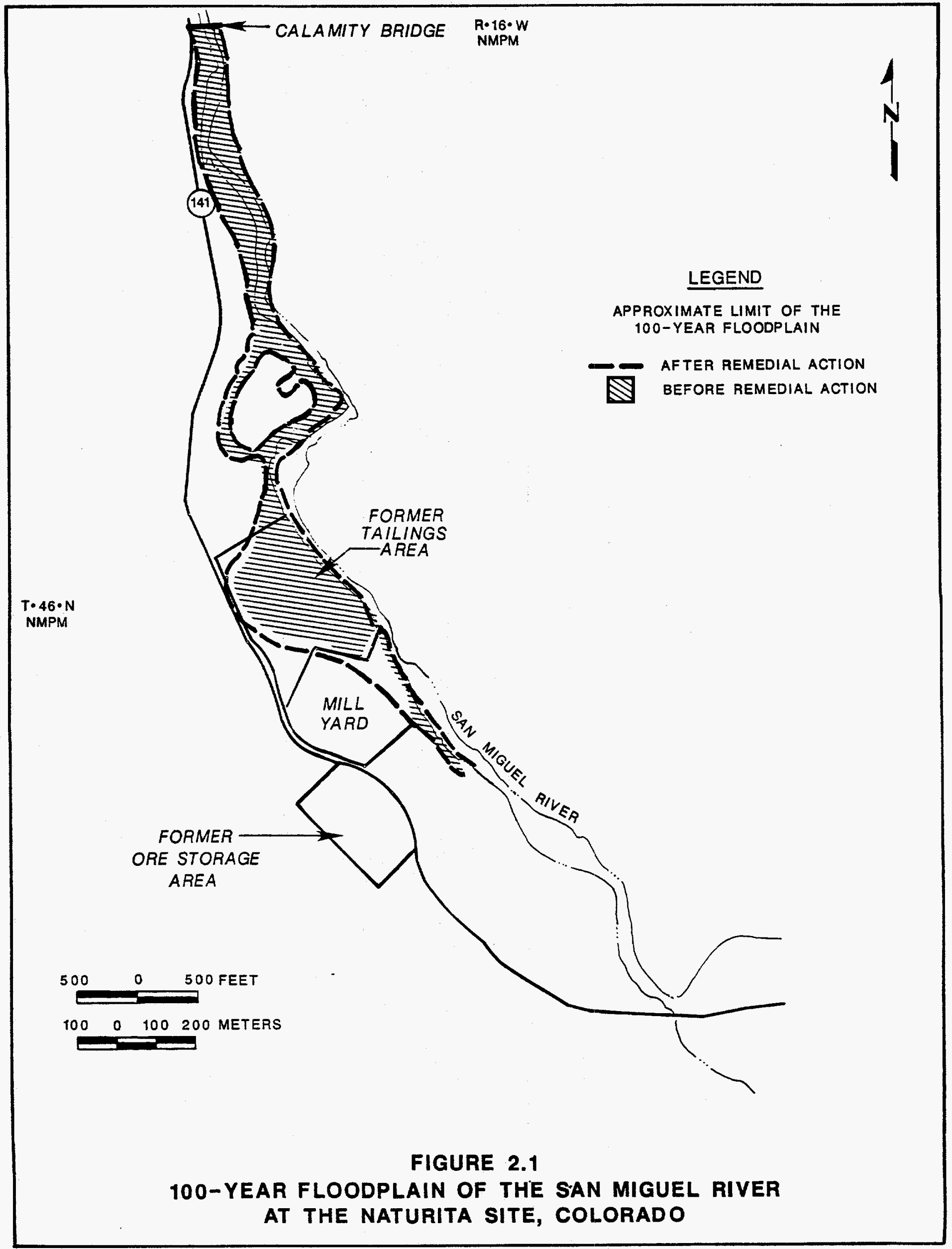


replaced with a gentle slope. This would result in a slight increase in the width of the 100-year floodplain, and approximately 38 ac (15 ha) at the Naturita site (Figure 2.1 ) would be inundated to an average depth of $5 \mathrm{ft}(1.5 \mathrm{~m})$ by a 100 year flood after remedial action.

In the vicinity of the Naturita site, migration of the eastern bank of the San Miguel River is constrained by an outcrop of resistant mudstone of the Jurassic Morrison Formation. This mudstone would not be disturbed by the remedial action. The western bank of the river would be restored after the remedial action, but the man-made terraces in the mill yard would be replaced with a gentle slope. This would result in a slight increase in the width of the 100-year floodplain at the site. The gentle slope of the western bank would not restrict the river's flow, and the clean fill material would not be expected to be more susceptible to erosion than naturally deposited river sediments. Therefore, remedial action would not affect the path or flow regime of the San Miguel River in the vicinity of the Naturita site. 


\subsection{WETLANDS ASSESSMENT}

\subsection{WETLANDS DESCRIPTION}

The riparian areas along the San Miguel River at the Naturita processing site were examined during five field trips to the site from 1986 to 1992 (TAC, $1986 ; 1988 ; 1990 ; 1991$; and 1992). The riparian areas occupy narrow bands along reaches of the river that are flanked by steep hillsides and broader expanses of relatively level ground where the river flows away from the hillsides (Figure 3.1). The vegetation in the narrow bands grows in three distinct zones. The zone closest to the river is the cottonwood/willow seedling plant community and consists of sandy and rocky bars that are flooded frequently. The dominant woody plant species are cottonwood and willow seedlings. Other commonly observed species are salt cedar, yellow sweet-clover, horsetail, sedges, and rushes. The cottonwood/willow sapling zone typically occurs on terraces above the river and is dominated by a dense growth of cottonwood saplings and willow. This zone is flooded much less frequently than the sandy bars, and a deep build-up of soil has taken place. Other woody plant species in this plant community are salt cedar, Russian olive, squawbush, and wild rose. The ground cover is very dense and dominated by grass. The upper zone is dominated by mature cottonwoods that typically grow up to the base of the hillsides and mark the beginning of the upland plant communities. The ages of these stands of cottonwood vary as indicated by size. Some stands are dominated by trees 25 to $35 \mathrm{ft}(8$ to $11 \mathrm{~m})$ tall, while most trees in older stands are 45 to $55 \mathrm{ft}(14$ to $17 \mathrm{~m})$ tall. Within these stands, cottonwood is the only canopy species; willow, salt cedar, squawbush, and rabbitbrush are scattered in the understory. The ground cover is fairly dense, although not as dense as in the cottonwood/willow sapling zone, principally because of reduced penetration of light onto the forest floor.

The plant communities in the broader expanses of the riparian areas are an interspersion of various types (Figure 3.1). Low-lying areas are dominated by willow. Drier ground is typically covered by cottonwood stands of various ages, with willow and other woody species in the understory and a ground cover of grass and herbs. Still drier areas are covered by the upper riparian shrub plant community. This plant community is typically open, and few cottonwoods are present. Riparian shrubs such as willow and squawbush and more upland plant species such as rabbitbrush and big sagebrush grow in fairly dense stands in this plant community. As in most of the riparian areas, there is a dense ground cover of grasses and herbs.

Dry Creek is an intermittent tributary of the San Miguel River and enters the river approximately 1 air mi $(2 \mathrm{~km})$ southeast of the Naturita processing site. Dry Creek passes within 0.5 air mi $(1 \mathrm{~km})$ of the Coke Oven borrow site and within 1 air mi $(2 \mathrm{~km})$ of the Dry Flats disposal site. Dry Creek was surveyed for riparian areas from 1990 to 1993, beginning in the area of the Coke Oven borrow site and proceeding approximately $3 \mathrm{mi}(5 \mathrm{~km}$ ) upstream (Figure 3.2). During the surveys, there were sections that contained water with little or no 


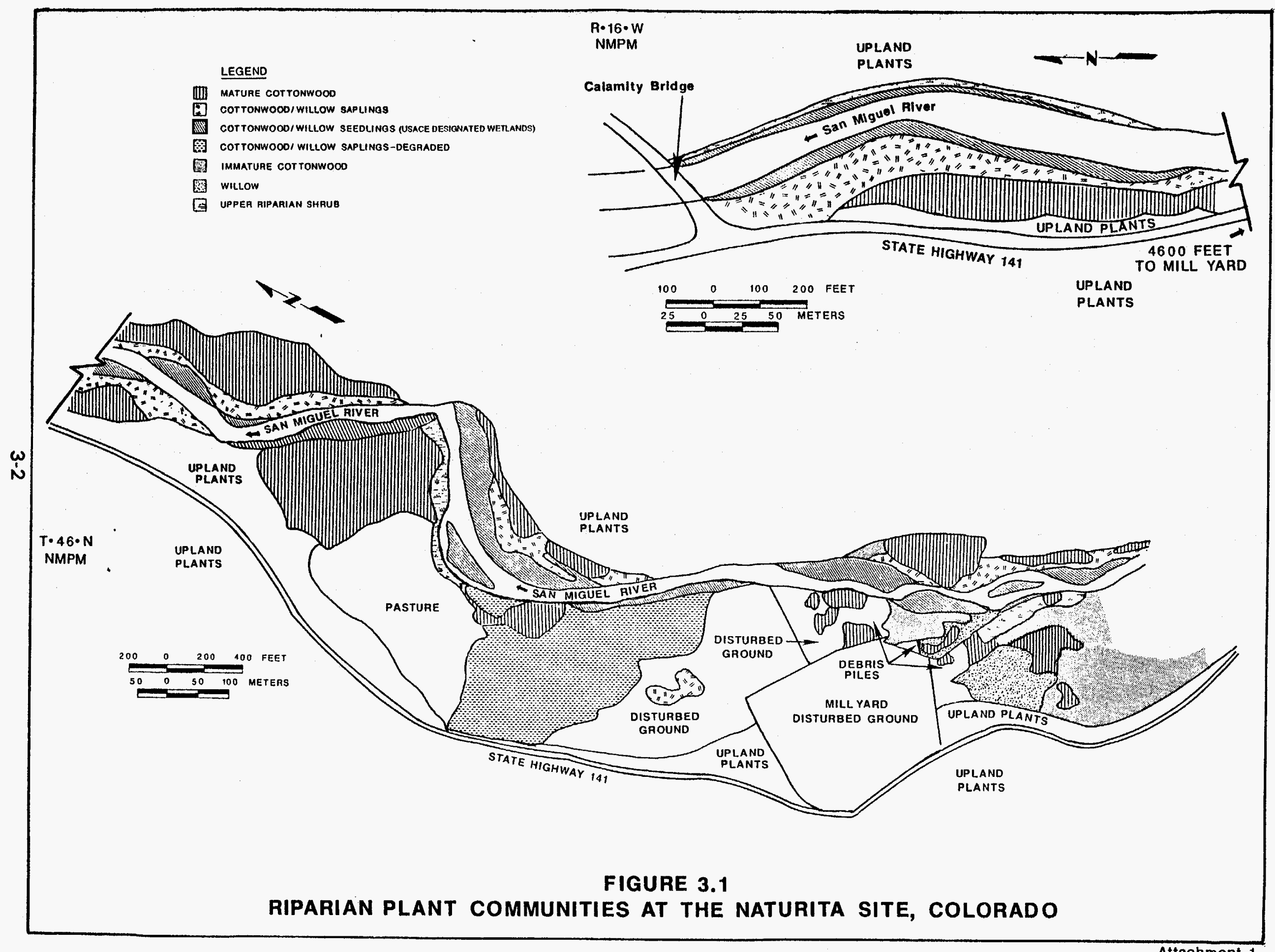




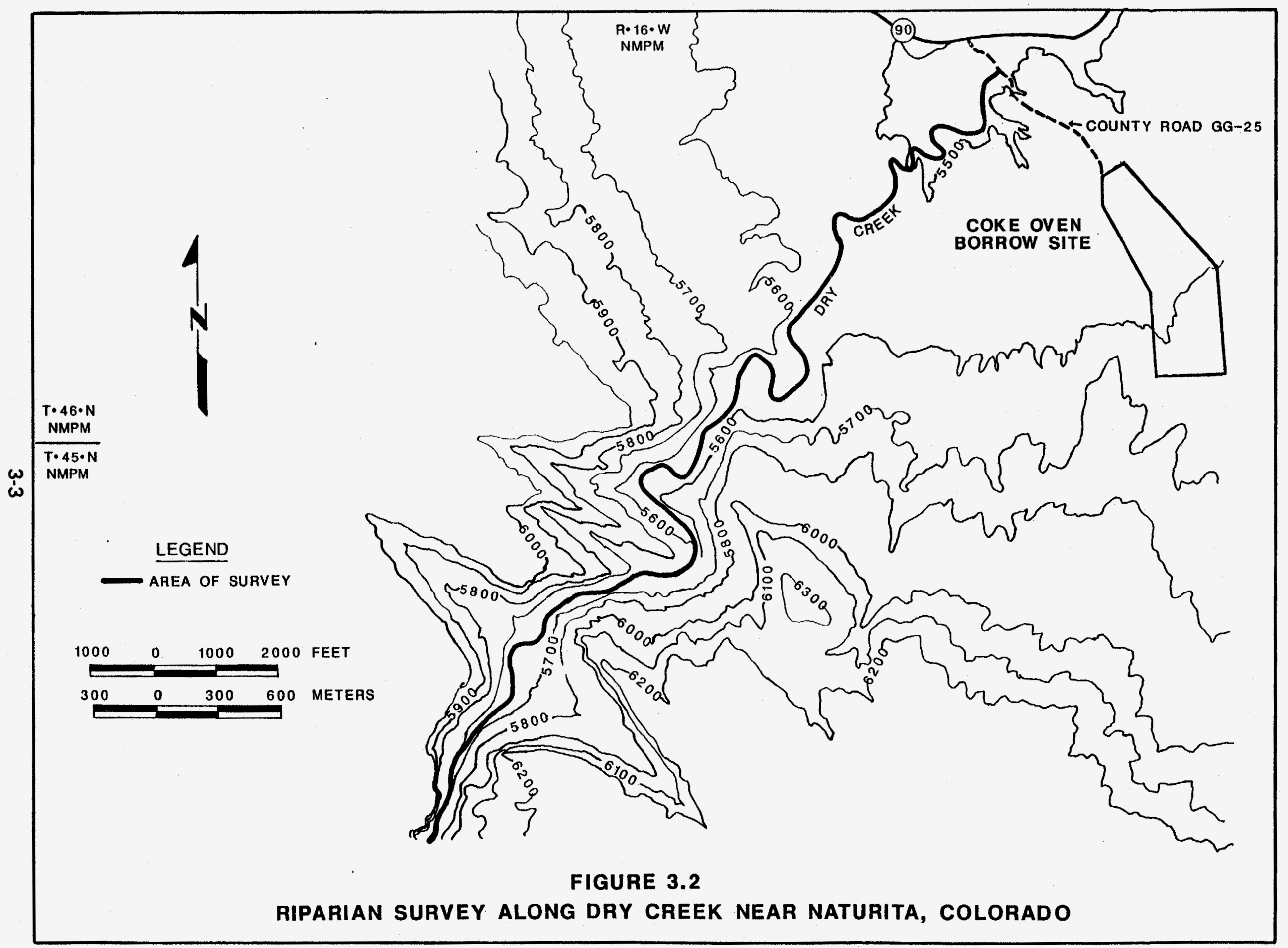


flow interspersed with dry sections. Riparian vegetation growing in narrow bands along the creek is composed mostly of willow and salt cedar. Other woody shrubs such as rabbitbrush, wild rose, and privet were also observed. Widely scattered, solitary, or small groves of mature Fremont cottonwoods were encountered along this otherwise open riparian zone.

During the course of the field work along the San Miguel River and Dry Creek, wildlife were observed as described in Attachment 2, Biological Assessment. Detailed surveys for amphibians and reptiles were not conducted, but their occurrences were noted during the field work. Six species of amphibians and reptiles were observed in the riparian plant communities, and at least five additional species are expected to occur. Bird surveys in the riparian habitat along the San Miguel River were conducted principally during the nesting season. Sixty-four species were recorded, and at least 27 species of birds nest in the riparian habitat along Dry Creek. At least 19 species of mammals may occur in the riparian habitat along the San Miguel River and Dry Creek. Beaver sign was observed along both watercourses. In 1986, there was much fresh beaver sign, and small beaver dams had been constructed in the drainages that run through the dense growth of cottonwoods in the former tailings area. Observations in 1988 revealed very little fresh beaver sign. One active beaver dam was observed along Dry Creek.

In September 1992, the riparian plant communities along the San Miguel River were inspected by a biologist from the USACE. It was determined that the cottonwood/willow seedling plant community was the only plant community that met the USACE definition of a wetland. The other riparian plant communities failed to meet the USACE criteria for jurisdictional wetlands because they are not flooded for sufficient duration during the growing season and they lack hydric soils (Jacobsen, 1992). The riparian plant communities along Dry Creek were not inspected by the USACE, but a small portion of the creek could be affected by the improvement of County Road GG-25 to provide access to the Dry Flats disposal site and Coke Oven borrow site. County Road GG-25 crosses Dry Creek between State Highway 90 and the Coke Oven borrow site (Figure 3.2), and culverts would be installed at this crossing. It is estimated that a maximum of 0.5 ac $(0.2$ ha) of riparian plant communities would be disturbed by this culvert installation, and, for the purpose of this assessment, it was assumed that these riparian plant communities would meet the USACE definition of a wetland.

\subsection{WETLAND IMPACTS AND MITIGATION}

Approximately 47 ac (19 ha) of riparian plant communities have been contaminated along the San Miguel River (Table 3.1). The largest riparian plant community that would be cleared during the remedial action is the 14 ac (6 ha) of degraded cottonwood/willow saplings that developed in the former tailings area after the tailings were removed (Figure 3.1). This area supported a healthy stand of cottonwood saplings and willows in 1986 (TAC, 1986); a subsequent die-off of cottonwoods and willows has produced much open ground and 
contributed to the degraded nature of this plant community (TAC, 1990, 1991, and 1992). Mature [13-ac (5-ha)] and immature [8-ac (3-ha)] cottonwood stands would be the next largest plant communities impacted by remedial action. These stands occur principally at the west end of the processing site area. The remaining plant community types that would be impacted are 7 ac ( $3 \mathrm{ha}$ ) of cottonwood/willow saplings and seedlings along the river, 2 ac (1 ha) of upper riparian shrub, and 3 ac ( 1 ha) of willow in the processing site area. The only riparian plant community that met the USACE definition of a wetland is the 4 ac ( $2 \mathrm{ha}$ ) of cottonwood/willow seedlings next to the river. It is estimated that another 0.5 ac (0.2 ha) of riparian plant communities along Dry Creek could be disturbed by the improvement of County Road GG-25, and it is assumed that these riparian plant communities would also meet the USACE definition of a wetland.

Table 3.1 Riparian plant communities at the Naturita site. Colorado

\begin{tabular}{lcc}
\hline \multicolumn{1}{c}{ Riparian plant community } & Acres & Hectares \\
\hline Mature cottonwood & 13 & 5 \\
Cottonwood/willow saplings & 3 & 1 \\
Cottonwood/willow seedlings & 4 & 2 \\
Immature cottonwood & 8 & 3 \\
Degraded cottonwood/willow saplings & 14 & 6 \\
Upper riparian shrub & 2 & 1 \\
Willow & 3 & 1 \\
\hline Total & 47 & 19 \\
\hline
\end{tabular}

Clearing 47.5 ac (19.2 ha) of riparian plant communities would constitute an unavoidable impact on vegetation and wildife. Riparian plant communities are much more productive in terms of plants and wildlife than the surrounding upland plant communities. For example, quantitative studies of breeding birds indicate that densities are 3 to 10 times higher in the riparian habitats than in the desert shrub habitat (Szaro and Jakle, 1985; Johnson and Carothers, 1982). Data from the riparian habitats along the San Miguel River and Dry Creek support this finding; 65 bird species were observed in the riparian habitats, while 29 were observed in the upland desert shrub habitat.

The clearing of vegetation from the riparian areas would temporarily reduce or prohibit wildlife use. Clearing of this vegetation could destroy less mobile wildife such as small mammals and reptiles and displace larger mammal and birds from the affected areas. The displaced wildlife could be forced to compete with wildlife in other areas for habitat or to use marginal habitat, resulting in a reduced survivorship for the displaced species. The duration of this impact would depend on the types of habitat restoration measures that would be implemented. 
The disturbance of wetlands is regulated by the USACE through its Section 404 Permit process; and the mitigation of remedial action impacts to wetlands would be determined by this process. The DOE would submit a Section 404 Permit application to the USACE for the remedial action activities that would affect wetlands. The USACE would publish a notice of availability for the review of the application. Section 404 Permit applications are usually reviewed by federal agencies such as the EPA and Fish and Wildlife Service (FWS), and this permit process may require that the DOE's permit address mitigation of the remedial action impacts to the 43 ac (17 ha) of riparian plant communities that do not meet the USACE definition of a wetland.

The DOE proposes to apply supplemental standards (Section 1.3) to a contaminated area adjacent to the Naturita processing site and west of the San Miguel River. This area does not contain any riparian habitat. If this application were approved by the NRC and state of Colorado, this area would not be cleaned up. Other areas at and adjacent to the processing site may be considered for supplemental standards, and these areas include those containing riparian plant communities and wetlands. If supplemental standards were applied to these areas, remedial action impacts to the 47.5 ac (19.2 ha) of riparian plant communities and wetlands would be reduced. Supplemental standards are discussed in Sections 3.1, 4.5, 5.1, 5.4, and 5.9 of the environmental assessment. 


\subsection{REFERENCES}

Jacobsen, K., 1992. U.S. Army Corps of Engineers, Grand Junction, Colorado, personal communication to Charles Burt, Jacobs Engineering Group Inc., Albuquerque, New Mexico, October 5, 1992.

Johnson, R. R., and S. W. Carothers, 1982. "Riparian Habitat and Recreation:

Interrelationships and Impacts in the Southwest and Rocky Mountain Region," in Eisenhower Consortium for Western Environmental Forestry Research, Bulletin 12. University of Arizona, Tucson, Arizona.

MKE (Morrison-Knudsen Engineers, Inc.), 1990. "Naturita Site Restoration in Areas Adjacent to the San Miguel River," Calculation No. 17-720-01-00. San Francisco, California.

Szaro, R. C., and M. D. Jakle, 1985. "Avian Use of a Desert Riparian Island and Its Adjacent Scrub Habitat," in The Condor, Vol. 87. pp. 511-519.

TAC (Technical Assistance Contractor), 1992. "Unpublished Field Notes, Naturita, Colorado, Uranium Mill Tailings Site," September 29, 1992, prepared by the TAC. Albuquerque, New Mexico, for the U.S. Department of Energy, UMTRA Project Office, Albuquerque Operations Office, Albuquerque, New Mexico.

TAC (Technical Assistance Contractor), 1991. "Unpublished Field Notes, Naturita, Colorado, Uranium Mill Tailings Site," June 18 through 21, 1991, prepared by the TAC, Albuquerque, New Mexico, for the U.S. Department of Energy, UMTRA Project Office, Albuquerque Operations Office, Albuquerque, New Mexico.

TAC (Technical Assistance Contractor), 1990. "Unpublished Field Report, Naturita, Colorado, Uranium Mill Tailings Site," June 11 through 14, 1990, prepared by the TAC, Albuquerque, New Mexico, for the U.S. Department of Energy, UMTRA Project Office, Albuquerque Operations Office, Albuquerque, New Mexico.

TAC (Technical Assistance Contractor), 1988. "Unpublished Field Notes, Naturita, Colorado, Uranium Mill Tailings Site," November 3, 1988, prepared by the TAC, Albuquerque, New Mexico, for the U.S. Department of Energy, UMTRA Project Office, Albuquerque Operations Office, Albuquerque, New Mexico.

TAC (Technical Assistance Contractor), 1986. "Unpublished Field Notes, Naturita, Colorado, Uranium Mill Tailings Site," June 9 and 11, 1986, prepared by the TAC, Albuquerque, New Mexico, for the U.S. Department of Energy, UMTRA Project Office, Albuquerque Operations Office, Albuquerque, New Mexico. 
USACE (U.S. Army Corps of Engineers), 1982. HEC-2 Water Surface Profile User's Manual, Computer Program 723-X6-L202A, Water Resources Support Center, The Hydrologic Engineering Center, Davis California.

USGS (United States Geological Survey), 1979. Water Resources Data for Colorado, Water Year 1978, Vol. 3, Dolores River Basin \& Green River Basin, USGS, Denver, Colorado.

\section{CODE OF FEDERAL REGULATIONS}

10 CFR Part 1022, "Compliance With Floodplain/Wetlands Environmental Review Requirements," Title 10, Code of Federal Regulations, Part 1022, U.S. Department of Energy, Office of the Federal Register, National Archives and Records Administration, Washington, D.C.

40 CFR Part 192, "Health and Environmental Protection Standards for Uranium and Thorium Mill Tailings," Title 40, Code of Federal Regulations, Part 192, U.S. Environmental Protection Agency, Office of the Federal Register, National Archives and Records Administration, Washington, D.C.

\section{EXECUTIVE ORDERS}

E011988, "Floodplain Management," May 24, 1977, Office of the President, Washington, D.C.

E011990, "Protection of Wetlands," May 24, 1977, Office of the President, Washington, D.C. 
ATTACHMENT 2

BIOLOGICAL ASSESSMENT 


\section{TABLE OF CONTENTS}

Section

Page

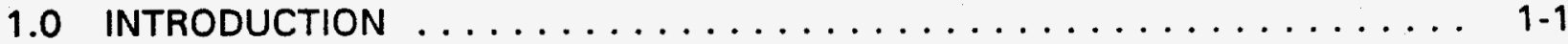

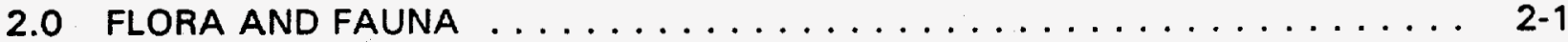

2.1 Naturita processing site . . . . . . . . . . . . . . . . . 2-1

2.2 Dry Flats disposal site and Coke Oven borrow site ............ 2-2

2.3 Impacts to flora and fauna .................... 24

3.0 THREATENED AND ENDANGERED SPECIES $\ldots \ldots \ldots \ldots \ldots \ldots \ldots \ldots \ldots$

3.1 Mammals ........................... $3-1$

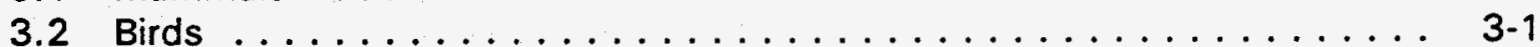

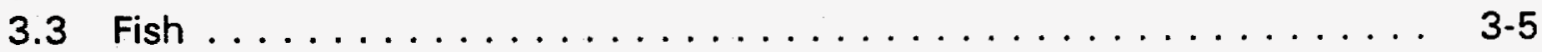

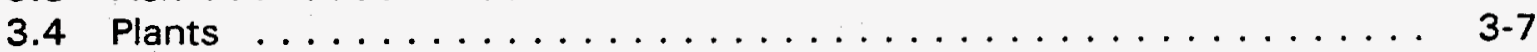

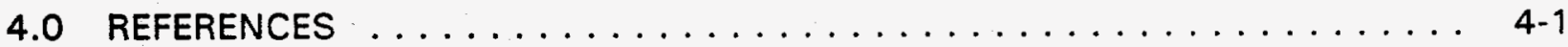

APPENDIX A CORRESPONDENCE WITH THE FISH AND WILDLIFE SERVICE 


\section{LIST OF FIGURES}

\section{Figure}

Page

3.1 Location of the calling willow flycatchers at the Naturita site, Colorado, in 1986

\section{LIST OF TABLES}

\section{Table}

2.1 Plant species observed in the area of the Naturita site, Colorado . . . . . . . 2-7

2.2 Fish species recorded in the San Miguel River at the Naturita site, Colorado .. 2-9

2.3 Amphibians and reptiles observed or expected to occur in the area of the Naturita site, Colorado . . . . . . . . . . . . . . . . . . . . . 2-9

2.4 Bird species observed in the area of the Naturita site, Colorado . . . . . . . . 2-10

2.5 Mammals observed or expected to occur in the area of the Naturita site, Colorado ................................ 2-12 


\section{LIST OF ACRONYMS AND ABBREVIATIONS}

\section{Acronym}

ac

DOE

EA

$\mathrm{ft}$

FR

FWS

ha

$\mathrm{km}$

$\mathrm{m}$

$\mathrm{mi}$

UMTRCA

USACE

\section{Definition}

acre

U.S. Department of Energy

environmental assessment

foot

Federal Register

Fish and Wildlife Service

hectare

kilometer

meter

mile

Uranium Mill Tailings Radiation Control Act of 1978

U.S. Army Corps of Engineers 


\subsection{INTRODUCTION}

Pursuant to the Uranium Mill Tailings Radiation Control Act (UMTRCA) of 1978, the U.S. Department of Energy (DOE) is proposing to conduct remedial action to clean up the residual radioactive materials (RRM) at the Naturita uranium processing site in Colorado. The proposed remedial action is to remove the RRM from the Naturita site to either the Uravan disposal site or the Dry Flats disposal site. To address the potential impacts of the remedial action on threatened and endangered species, the DOE prepared a biological assessment. Informal consultations with the Fish and Wildlife Service (FWS) were initiated in 1986, and the FWS provided a list of the threatened and endangered species that may occur in the Naturita study area. This list was updated by two FWS letters in 1988 and by verbal communication in 1990 (Leachman, 1990). The biological assessment was included in the environmental assessment (EA) of the proposed remedial action that was prepared in 1990.

The 1990 biological assessment provided the DOE's findings on the potential impacts of the proposed remedial action on threatened and endangered species. In a biological opinion dated December 11,1990, the FWS agreed with the DOE's findings but asked the DOE to determine if the proposed remedial action would jeopardize the continued existence of the razorback sucker. In 1991, the DOE responded that the San Miguel River would be used as a source of water for the remedial action, which would deplete water in the Upper Colorado River Basin. This depletion "may affect" the razorback sucker but would not jeopardize the continued existence of the species. The FWS agreed with this determination on February 25, 1991.

In 1993, the design for the Dry Flats disposal alternative was changed. This remedial action would now disturb an estimated total of 380 acres (ac) [153 hectares (ha)]: 133 ac (55 ha) at the processing site, 105 ac (42 ha) at the Dry Flats disposal site, 135 ac (55 ha) at the Coke Oven borrow site, and 8 ac ( $3 \mathrm{ha}$ ) for improving and constructing roads to the disposal site. The FWS was again consulted in 1993 and provided a new list of threatened and endangered species that may occur in the Naturita study area. The EA and the biological assessment have been revised in response to these changes. Copies of all correspondence with the FWS are provided in Appendix A to this biological assessment.

For this biological assessment, the Naturita study area consists of the Naturita processing site, the Dry Flats disposal site, the Coke Oven borrow site, and the associated haul road. The study area is in the Great Basin sagebrush habitat of the Colorado Plateau (Kuchler, 1975). The processing site is in the San Miguel River valley, which is surrounded by steep juniper-covered hillsides. Flat land is confined to the riparian zone along the river. The Dry Flats disposal site and the Coke Oven borrow site are in upland areas dominated by sagebrush and pinon-juniper plant communities. 


\subsection{FLORA AND FAUNA}

Information on the flora and fauna in the Naturita study area was obtained from field reconnaissance surveys (TAC, 1993, 1992, 1991, 1990, 1988, 1986; DOE, 1983), consultations with natural resource personnel from state and federal agencies, and reviews of pertinent literature. Lists of the flora and fauna observed or expected to occur in the major plant community types at the sites are provided in Tables 2.1 through 2.5 , which are presented at the end of this section.

\subsection{NATURITA PROCESSING SITE}

The vegetation at and near the processing site consists of three types: riparian, upland desert shrub, and bare ground with early successional plant species in disturbed areas (Table 2.1). The riparian vegetation growing along the San Miguel River grows in three distinct zones and is described in Attachment 1 , Floodplains and Wetlands Assessment. The upland desert shrub plant community occurs in small elevated areas along the river between the pockets of riparian vegetation. Common shrub species observed are greasewood, big sagebrush, squawbush, rabbitbrush, saltbush, yucca, prickly pear cactus, and Mormon tea. Widely scattered juniper, pinon pine, and Gambel's oak are also in this area. The ground cover is fairly dense and is dominated by grass and herbs.

Land areas have been disturbed in the mill yard and former tailings area. Much of the mill yard is flat, hard-packed gravel with little, if any, soil. As a result, there is much bare ground with very widely dispersed, early successional species such as Russian thistle and white sweet clover. Rabbitbrush is widely scattered in this area. Sloping areas within the mill yard have remnants of native vegetation; the plant species observed are similar to those observed in the upland vegetation growing between the pockets of riparian vegetation along the river. The eastern part of the former tailings area is rocky and largely devoid of vegetation. A dense growth of cottonwood saplings and young willows and salt cedars has developed in the western one-half of this area. Ground cover includes various species of grass and herbaceous species, including goldenrod, poison ivy, and sweet clover.

Bird surveys in the riparian habitats along the San Miguel River were conducted principally during the nesting season. Sixty-four species were recorded. Three nesting bird censuses were taken over a 6-year period along the San Miguel River from Calamity Bridge upriver to the processing site. These censuses showed the yellow warbler as the most common species. This warbler frequented all riparian habitat types. The spotted sandpiper was also common and was most often seen along the river. The western wood-pewee, northern oriole, house finch, and solitary vireo were frequently heard singing in the mature cottonwood stands. Nesting birds indicative of the shrubby riparian habitat were the yellow-breasted chat and blue grosbeak. The great-blue heron and belted kingfisher were occasionally seen fishing in the river but are not known to nest in the site area. Occasional solitary mallards or pairs of mallards 
were observed flying up and down the river, and one brood was heard calling from a dense stand of willow in 1986. The San Miguel River constitutes marginal nesting habitat for waterfowl because of the lack of brood escape cover, especially when the river is low. Nest sites for birds of prey have not been observed along the river, but the prairie falcon (Falco mexicanus) and golden eagle (Aquila chrysaetos) could use the area for foraging. The common barn owl (Tyto alba), long-eared owl (Asio otus), great horned owl (Bubo virginianus), western screech owl (Otus kennicotti), and burrowing owl (Athene cunicularia) could also occur in the area. Large numbers (up to 22) of turkey vultures have been roosting for a number of years in a stand of mature cottonwoods across the river from the processing site.

At least 19 species of mammals may occur in the riparian habitat along the San Miguel River and Dry Creek. Beaver sign was observed along both watercourses. In 1986, there was much fresh beaver sign, and small beaver dams had been constructed in the drainages that run through the dense growth of cottonwoods in the former tailings area. Observations in 1988 revealed very little fresh beaver sign. One active beaver dam was observed along Dry Creek. Mule deer were observed along the river, and their sign (droppings) was common. This area is likely a mule deer winter range but not a critical winter range. There are also year-round resident deer in the area.

Limited fish sampling in the San Miguel River resulted in six species being recorded (Table 2.2). The flannelmouth sucker and rainbow trout were the most common species collected.

\subsection{DRY FLATS DISPOSAL SITE AND COKE OVEN BORROW SITE}

The Dry Flats disposal and Coke Oven borrow sites are in upland areas dominated by sagebrush and pinon-juniper plant communities (Table 2.1). Specific plant species vary somewhat from site to site; however, the fauna at and near the sites are similar.

The Dry Flats disposal site is in the sagebrush plant community with pinonjuniper woods nearby. Areas of sagebrush at and near the site have been cleared, and small, reinvading sagebrush is the most common shrub species. Other widely scattered species are rabbitbrush, broom snakeweed, juniper, prickly pear, yucca, and Mormon tea. There is much bare ground between the woody species, and the ground cover is a sparse growth of grass and herbs. Uncleared sagebrush has a much denser growth of woody plants, with sagebrush by far the most common species. The species in the cleared sagebrush zone also grow in the sagebrush plant community. The low ridges at and around the Dry Flats site are covered with an open growth of pinon-juniper woods. Big sagebrush is the dominant understory shrub; other species of shrubs are the same as those observed in the nearby sagebrush plant community. 
Sagebrush, greasewood, pinon-juniper woods, and riparian plant communities occur in the area of the Coke Oven borrow site. The sagebrush plant community covers an extensive amount of land in the borrow site area. Sagebrush is the most common species; other shrub species include greasewood, rabbitbrush, and four-winged saltbush. Grass and various herbaceous species, including Indian paintbrush and scarlet globe mallow, make up the sparse ground cover. The greasewood-dominated plant community occurs mostly west of Dry Creek. Other species in this plant community are the same as those recorded in the sagebrush plant community. The pinon-juniper woods occur on the ridge south of the Coke Oven site, and the understory and ground cover plant species are similar to those recorded in the sagebrush plant community. Gambel's oak and mountain mahogany are also common in the pinon-juniper woods. The riparian vegetation occurs along Dry Creek approximately 2000 feet $(\mathrm{ft})[610$ meters $(\mathrm{m})]$ to the north and west. The vegetation growing along the border of the creek is dominated by shrubs. Willow is the most common species and grows in dense strips in places. Salt cedar is quite common in places, and large cottonwoods grow individually or in small clumps along the creek. Other species noted along the creek are sagebrush, rabbitbrush, greasewood, rush, bulrush, and yellow sweet clover.

The haul road to the Dry Flats disposal site and Coke Oven borrow site would pass through sagebrush and pinon-juniper plant communities, and the species of plants within these areas are comparable to those observed in similar plant community types described above. The Dry Flats disposal site, the Coke Oven borrow site, and the haul road to these sites would be in similar plant community types, so the following discussion regarding fauna would apply to these sites and road. The collared lizard, sagebrush lizard, and plateau striped whiptail were observed at the Dry Flats site, while these species and the fence lizard, bull snake, and garter snake were observed near the Coke Oven site. An additional eight species would be expected to occur in these areas (Table 2.3).

A total of 30 species of birds were recorded in the upland desert shrub and pinon-juniper plant communities (Table 2.4). The meadowlark and rock wren were common in the desert shrub, while the blue-gray gnatcatcher and the black-throated gray warbler were species observed only in the pinon-juniper woods. The red-tailed and Cooper's hawks were the only birds of prey observed. A red-tailed hawk was observed flying in the area of the Dry Flats site; however, no raptor nests were observed at or near this site. A female Cooper's hawk in immature plumage was observed in a clump of cottonwoods along Dry Creek.

Surveys have shown that at least 27 species of birds nest in the riparian habitats along Dry Creek. The northern oriole, western kingbird, ash-throated flycatcher, and northern mockingbird were common and were most often in the clumps of cottonwoods. The rufous-sided towhee, yellow warbler, and lark sparrow frequented the shrubby riparian habitat. Nest sites for birds of prey were not observed in the riparian habitat along Dry Creek. A Cooper's hawk was flushed from a small grove of cottonwoods in 1986, but a search of the 
area failed to reveal a nest site. The prairie falcon and golden eagle could use the area for foraging. A potential prairie falcon aerie was observed on a ledge of a high cliff at the upper end of the survey area in June 1990, but no falcons were observed. The great horned and burrowing owls could occur in the area of the Dry Flats and Coke Oven sites.

At least 26 species of mammals may occur in the upland habitat at or near the Dry Flats disposal and Coke Oven borrow sites (Table 2.5). Two small towns of Gunnison prairie dogs were observed in the northern portion of the Dry Flats disposal site and at the northwestern corner of the Coke Oven borrow site. Each town contained approximately 20 active burrows. Mule deer sign (droppings) was observed throughout the area. The area likely supports a yearround population of deer, and there may be an increase in deer numbers in the winter. However, judging from the amount of deer sign, it is not a critical deer wintering area. Some elk droppings were observed in the pinon-juniper woods south of the Coke Oven site and likely represent elk that winter in small numbers in this area.

\section{$2.3 \quad$ IMPACTS TO FLORA AND FAUNA}

Flora and fauna would be affected directly and indirectly by remedial action. Direct effects would include the loss of habitat, loss of less mobile wildlife species, and displacement of other wildlife species. Indirect effects would arise from increased fugitive dust, noise levels, and human activity. The duration of the direct effects would depend on the level of restoration, and indirect effects would last for the duration of the remedial action or less.

Remedial action at the Naturita site would disturb approximately 380 ac (153 ha) of land. Most of this land consists of upland sagebrush and pinon-juniper plant communities [292.5 ac (118.4 ha)], followed by riparian vegetation [47.5 ac (19.2 ha)] and previously disturbed ground with little vegetation [40 ac (16 ha)]. The riparian plant communities along the San Miguel River and Dry Creek are productive in terms of flora and fauna and are relatively scarce in the region. Consultation with the U.S. Army Corps of Engineers (USACE) indicated that only 4 ac ( 2 ha) of cottonwood/willow seedlings along the San Miguel River meet the USACE definition of a wetland (Section 3.0 of Attachment 1). The remaining riparian plant communities along the river do not meet the USACE definition of a wetland because they lack the proper hydrological conditions (Jacobsen, 1992). The USACE did not inspect the riparian plant communities along. Dry Creek, but it is assumed that approximately 0.5 ac ( 0.2 ha) of wetland area along Dry Creek could be disturbed by improvement of the haul road to the Dry Flats disposal site and Coke Oven borrow site. The 292.5 ac $(118.4$ ha) of sagebrush and pinon-juniper plant communities represent the second most productive habitat types that would be disturbed. These habitat types are common in the area, and the land to be affected is not in any important wildlife habitat (e.g., critical deer winter range). 
The clearing of vegetation from the riparian areas would temporarily reduce or prohibit wildlife use. The duration of this effect would depend on the level of restoration undertaken. Remedial action would remove not only the vegetation but also some of the soil. This soil could not be stockpiled because it is contaminated and must be incorporated into the disposal cell. Research has shown that the rate of vegetation recovery on mine spoil varies widely. depending on the restoration methods employed (Aldon, 1981; Wagner et al., 1978). The hypothetical maximum effect would result from no restoration except recontouring, which would result in the recovery of the biotic community on land devoid of topsoil. In this case, primary succession [i.e., a sequence of plant communities developing in a newly exposed habitat devoid of life (Ricklefs, 1979/1 would take place and recovery would take years (Evans et al., 1978). However, recent experience has shown that procedures such as fertilization, use of proper seed mixtures, pole planting in riparian habitats, and protection from grazing can enhance successful revegetation [(Richardson et al., 1986; Swenson and Mullins, 1985; York, 1985)]. Prior to any surface disturbance, plans for restoring excavated areas would be developed by the RAC and the DOE in consultation with the appropriate regulatory agency or other authority. In general, these plans would involve backfilling, recontouring, and revegetation. Effects would be mitigated by performing restoration as soon as possible after the completion of surface-disturbing activities.

The effects on game species at the Naturita site are expected to be minimal. The mule deer is a year-round resident at the Naturita processing. Dry Flats disposal, and Coke Oven borrow sites; however, habitat features such as critical winter range do not occur at or near the sites that could be disturbed during remedial action. Parts of the small towns of Gunnison prairie dogs at the Dry Flats disposal and Coke Oven borrow sites could be temporarily disturbed during the remedial action. A limited amount of waterfowl production occurs along the San Miguel River in the site area, but remedial action activities would be expected to have a minimal effect on waterfowl production. The effects on birds of prey at the site would also be expected to be minimal to nonexistent. No large hawks are known to nest in the cottonwood stands that may be affected. The kestrel and certain species of small owls may nest in these areas and be affected. The Cooper's hawk may nest along Dry Creek, but potential nesting sites are well removed from the area of Dry Creek that could be affected by remedial action.

An analysis of possible effects on threatened and endangered species is presented in Section 3.0 of this biological assessment. This analysis indicates that there would be no direct effects on threatened and endangered species and other species of concern except possibly on the southwestern willow flycatcher (Epidonax traillii extimus), flannelmouth sucker (Catastomus latipinnis), and roundtail chub (Gila robusta). The southwestern willow flycatcher was proposed for listing as an endangered species on July 23, 1993 [58 Federal Register (FR) 39495]. This bird species was heard calling along the San Miguel River in 1986; however, this species was not observed or heard along the San Miguel River or Dry Creek in 1990 through 1993. It was therefore determined 
that the southwestern willow flycatcher does not currently nest in the areas that could be affected by remedial action. A survey for this bird species would be conducted again in 1994. If this survey revealed that the southwestern willow flycatcher nests in areas that would be affected by the remedial action, a mitigation plan would be prepared in consultation with the FWS. One possible mitigation measure would be to limit remedial action activities in the habitat of the southwestern willow flycatcher.

Remedial action activities would take place in the 100-year floodplain of the San Miguel River and would have the potential to directly affect the flannelmouth sucker and roundtail chub through alteration of the San Miguel River. However, negative impacts could be minimized by not performing remedial action in the river, recontouring and revegetating disturbed ground as soon as possible, using erosion control measures such as mulch and berms where needed, and possibly implementing supplemental standards to exclude as much area as possible along the river from cleanup activities. It is anticipated that implementation of these measures would result in little, if any, negative impact to these fish. In addition. the removal of contaminated materials that pose a potential ecological risk to the terrestrial and aquatic ecosystems may have a positive impact on the species, along with other species in the terrestrial and aquatic ecosystems.

Water from the San Miguel River would be used for the remedial action le.g., for dust control and equipment washing). This water use would result in a net depletion of water in the upper Colorado River basin that would result in a "may affect" determination for the Colorado squawfish, humpback chub, bonytail chub, and razorback sucker. In addition, it was determined that this depletion would adversely affect the critical habitat of these fish species. These determinations would require formal conferencing with the FWS and would likely result in the payment of a dollar amount per acre-foot of the average annual water withdrawal for the remedial action. It is estimated that the Dry Flats disposal alternative would require an average annual water withdrawal of 86 acre-feet from the San Miguel River. 
Table 2.1 Plant species observed in the area of the Naturita site, Colorado

\begin{tabular}{|c|c|c|c|}
\hline \multirow[b]{2}{*}{ Scientific name } & \multirow[b]{2}{*}{ Common name } & \multicolumn{2}{|c|}{ Habitat } \\
\hline & & Riparian & Upland \\
\hline \multicolumn{4}{|c|}{ TREES AND SHRUBS } \\
\hline Artemesia tridentata & big sagebrush & & $x$ \\
\hline Atriplex canescens & four-wing saltbush & & $x$ \\
\hline Atriplex sp. & saltbush & & $x$ \\
\hline Cercocarpus montanus & mountain mahogany & & $x$ \\
\hline Chrysothamnus nauseosus & golden rabbitbrush & $x$ & $x$ \\
\hline Chrysothamnus viscidiflorus & rabbitbrush & $x$ & $\mathrm{x}$ \\
\hline Clematis ligusticifolia & western virgin's bower & $x$ & \\
\hline Elaeagnus angustifolia & Russian olive & $x$ & \\
\hline Ephedra sp. & Mormon tea & & $x$ \\
\hline Forestiera neomexicana & privet & $x$ & \\
\hline Gutierrezia sarothrae & broom snakeweed & & $x$ \\
\hline Juniperus sp. & juniper & & $x$ \\
\hline Opuntia sp. & prickly pear & $x$ & $x$ \\
\hline Pinus edulis & pinon pine & & $x$ \\
\hline Populus angustifolia & narrowleaf cottonwood & $\mathrm{X}$ & \\
\hline Populus fremontii & Fremont cottonwood & $x$ & \\
\hline Quercus gambelii & Gambel's oak & & $\mathrm{X}$ \\
\hline Rhus radicans & poison ivy & $x$ & \\
\hline Rhus fendleri & squawbush & $x$ & \\
\hline Rosa fendleri & Fendler rose & $\mathrm{x}$ & \\
\hline Salix sp. & willow & $x$ & \\
\hline Salsola kali & Russian thistle & $x$ & $x$ \\
\hline Sarcobatus vermiculatus & greasewood & $x$ & $x$ \\
\hline Shepherdia argentea & silver buffaloberry & $x$ & \\
\hline Tamarix parviflora & salt cedar & $x$ & \\
\hline Yucca baccata & banana yucca & & $x$ \\
\hline Yucca sp. & yucca & & $x$ \\
\hline \multicolumn{4}{|c|}{ FORBS AND HERBS } \\
\hline Asclepias sp. & milkweed & & $x$ \\
\hline Astragalus sp. & milkvetch & & $x$ \\
\hline Castilleja sp. & paintbrush & & $x$ \\
\hline Cirsium sp. & thistle & $x$ & $x$ \\
\hline Cordylanthus wrightii & birdbeak & & $x$ \\
\hline Equisetum arvense & common horsetail & $x$ & \\
\hline Eriogonum racemosum & red-root buckwheat & & $x$ \\
\hline Helianthus annuus & common sunflower & & $x$ \\
\hline Lactura Iudoviciana & western lettuce & & $x$ \\
\hline Leucelene ericoides & baby white aster & & $x$ \\
\hline
\end{tabular}


Table 2.1 Plant species observed in the area of the Naturita site, Colorado (Concluded)

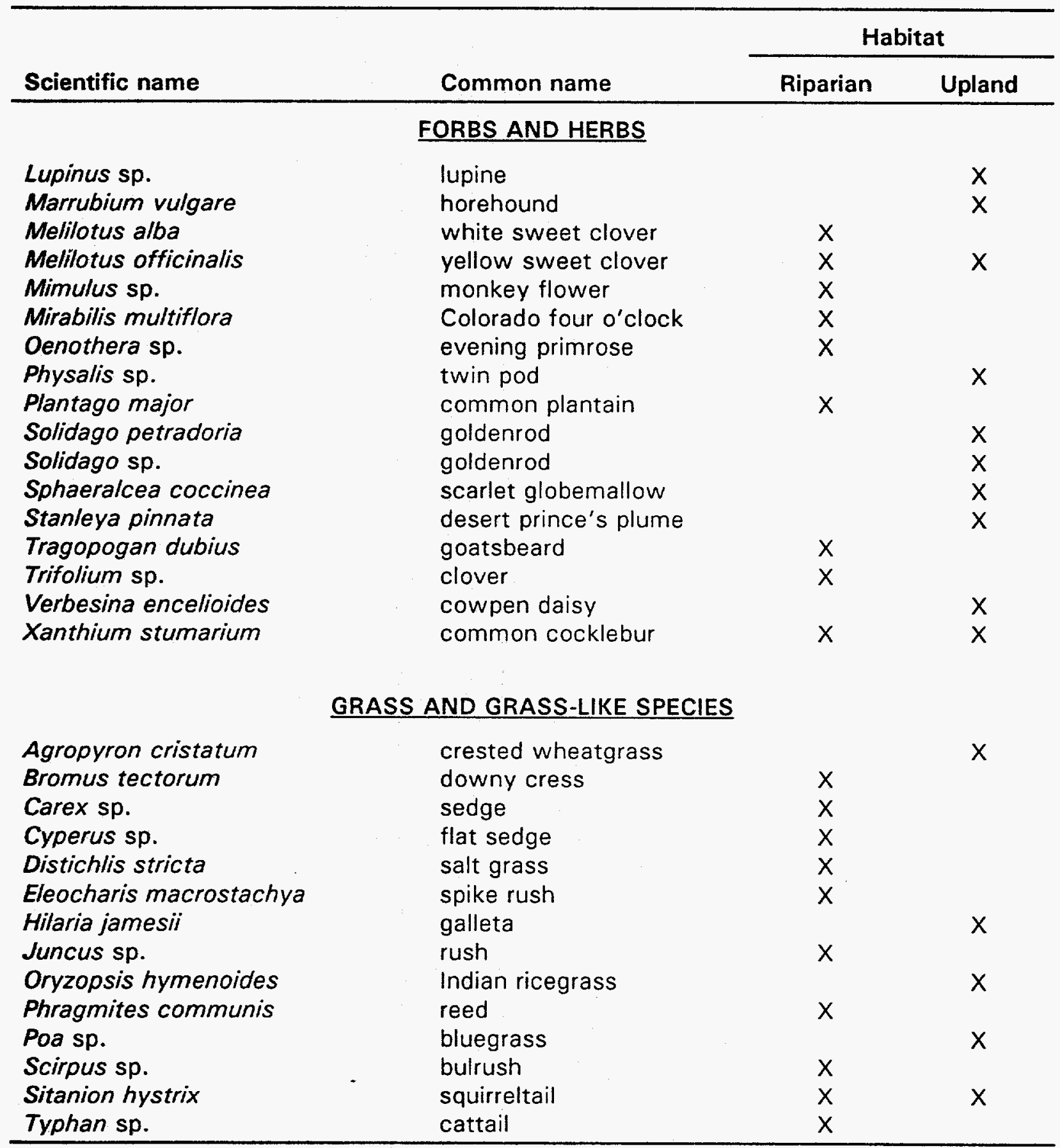

Ref. TAC, 1988, 1986; DOE, 1983. 
Table 2.2 Fish species recorded in the San Miguel River at the Naturita site, Colorado

\begin{tabular}{ll}
\hline Scientific name & Common name \\
\hline Salmo giarderneri & rainbow trout \\
Salmo clarki & cutthroat trout \\
Rhinichthys osculus & speckled dace \\
Catostomus discobolus & bluehead sucker \\
Catostomus latipinnis & flannelmouth sucker \\
Cottus bairdi & mottled sculpin \\
\hline
\end{tabular}

Ref. CDOW, 1977.

Table 2.3 Amphibians and reptiles observed or expected to occur in the area of the Naturita site, Colorado

\begin{tabular}{|c|c|c|c|}
\hline \multirow[b]{2}{*}{ Scientific name } & \multirow[b]{2}{*}{ Common name } & \multicolumn{2}{|c|}{ Habitat } \\
\hline & & Riparian & Upland \\
\hline Ambystoma tigrinum & tiger salamander & $x$ & $x$ \\
\hline Scaphiopus multiplicatus & New Mexico spadefoot & & $x$ \\
\hline Bufo punctatus & red-spotted toad & & $x$ \\
\hline Bufo woodhousil ${ }^{a}$ & Woodhouse's toad & $x$ & \\
\hline Rana pipiens & northern leopard frog & $x$ & \\
\hline Crotaphytus collaris $^{a}$ & collared lizard & & $x$ \\
\hline Phrynosoma douglassii & short-horned lizard & & $x$ \\
\hline Sceloporus graciosus ${ }^{a}$ & sagebrush lizard & & $x$ \\
\hline Sceloporus undulatus ${ }^{a}$ & eastern fence lizard & $x$ & $x$ \\
\hline Urosaurus ornatus & tree lizard & & $x$ \\
\hline Uta stansburiana & side-blotched lizard & & $x$ \\
\hline Cnemidophorus tigris ${ }^{a}$ & western whiptail & $x$ & \\
\hline Cnemidophorus velox & plateau striped whiptail & $x$ & $x$ \\
\hline Elaphe guttata & corn snake & $x$ & \\
\hline Masticophis taeniatus & striped whipsnake & & $x$ \\
\hline Pituophis melanoleucus ${ }^{a}$ & bull snake & $x$ & $x$ \\
\hline Thamnophis elegans ${ }^{a}$ & western terrestrial & & \\
\hline & garter snake & $x$ & $x$ \\
\hline Crotalus viridis & western rattlesnake & $x$ & $x$ \\
\hline Opheodrys vernalis ${ }^{a}$ & smooth green snake & $x$ & \\
\hline
\end{tabular}

aspecies observed at or near the site.

Ref. TAC, 1990, 1988, 1986; Hammerson, 1986; DOE, 1983. 
Table 2.4 Bird species observed in the area of the Naturita site, Colorado

\begin{tabular}{|c|c|c|c|}
\hline \multirow[b]{2}{*}{ Scientific name } & \multirow[b]{2}{*}{ Common name } & \multicolumn{2}{|c|}{ Habitat } \\
\hline & & Riparian & Upland \\
\hline Ardea herodias & great blue heron & $x$ & \\
\hline Anas platyrhynchos & mallard & $x$ & \\
\hline Charadrius vociverus & killdeer & $x$ & \\
\hline Actitis macularia & spotted sandpiper & $x$ & \\
\hline Cathartes aura & turkey vulture & $x$ & $\mathrm{x}$ \\
\hline Accipiter cooperii & Cooper's hawk & $x$ & $x$ \\
\hline Buteo jamaicensii & red-tailed hawk & $x$ & $x$ \\
\hline Falco sparverius & American kestrel & $x$ & $\mathrm{x}$ \\
\hline Phasianus colchicus & ring-necked pheasant & $x$ & \\
\hline Columba livia & rock dove & $x$ & \\
\hline Zenaida macroura & mourning dove & $x$ & $\mathrm{x}$ \\
\hline Chordeiles minor & common nighthawk & $x$ & $x$ \\
\hline Aeronautes saxatalis & white-throated swift & $x$ & \\
\hline Ceryle alcyon & belted kingfisher & $x$ & \\
\hline Selasphorus platycercus & broad-tailed hummingbird & $x$ & \\
\hline Archilochus alexandri & black-chinned hummingbird & $x$ & \\
\hline Colaptes auratus & northern flicker & $x$ & \\
\hline Melanerpes lewis & Lewis woodpecker & $x$ & \\
\hline Sphyrapicus nuchalis & red-naped sapsucker & $x$ & \\
\hline Tyrannus verticalis & western kingbird & $x$ & \\
\hline Myiarchus cinerascens & ash-throated flycatcher & $x$ & \\
\hline Contopus sordidulus & western wood pewee & $x$ & \\
\hline Sayornis saya & Say's phoebe & $x$ & \\
\hline Empidonax wrightii & gray flycatcher & $x$ & \\
\hline Empidonax traillii & willow flycatcher & $x$ & \\
\hline Eremophila alpestris & horned lark & & $x$ \\
\hline Tachycineta thalassina & violet-green swallow & $x$ & \\
\hline Stelgidopteryx serripennis & $\begin{array}{l}\text { northern rough-winged } \\
\text { swallow }\end{array}$ & & \\
\hline Hirundo pyrrhonota & cliff swallow & $\begin{array}{l}x \\
x\end{array}$ & \\
\hline Hirundo rustica & barn swallow & $x$ & \\
\hline Gymnorhinus cyanocephalus & pinon jay & & $x$ \\
\hline Aphelocoma coerulenscens & scrub jay & & $x$ \\
\hline Pica pica & black-billed magpie & $x$ & \\
\hline Corvus brachyrhynchos & American crow & $x$ & \\
\hline Corvus corax & common raven & & $x$ \\
\hline Parus inornatus & house wren & $x$ & \\
\hline Parus atricapillus & black-capped chickadee & $x$ & \\
\hline Troglodytes aedon & plain titmouse & & $\mathrm{x}$ \\
\hline Salpinctes obsoletus & rock wren & & $x$ \\
\hline Catherpes mexicanus & canyon wren & & $x$ \\
\hline
\end{tabular}


Table 2.4 Bird species observed in the area of the Naturita site, Colorado (Concluded)

\begin{tabular}{|c|c|c|c|}
\hline \multirow[b]{2}{*}{ Scientific name } & \multirow[b]{2}{*}{ Common name } & \multicolumn{2}{|c|}{ Habitat } \\
\hline & & Riparian & Upland \\
\hline Polioptila caerulea & blue-gray gnatcatcher & & $x$ \\
\hline Regulus calendula & ruby-crowned kinglet & $x$ & $x$ \\
\hline Sialia mexicana & western bluebird & & $x$ \\
\hline Turdus migratorius & American robin & $x$ & \\
\hline Dumetella carolinensis & gray catbird & $x$ & \\
\hline Minus polyglottos & northern mockingbird & $x$ & $x$ \\
\hline Sturnus vulgaris & European starling & $x$ & \\
\hline Vireo vicinior & gray vireo & & $x$ \\
\hline Vireo solitarius & solitary vireo & $x$ & $x$ \\
\hline Vireo gilvus & warbling vireo & $x$ & \\
\hline Vermivora celata & orange-crowned warbler & $x$ & \\
\hline Dendroica coronata & yellow-rumped warbler & $x$ & \\
\hline Dendroica fusca & blackburnian warbler & $x$ & \\
\hline Dendroica nigrescens & $\begin{array}{l}\text { black-throated gray } \\
\text { warbler }\end{array}$ & & $x$ \\
\hline Dendroica petechia & yellow warbler & $x$ & \\
\hline Icteria virens & yellow-breasted chat & $x$ & \\
\hline Pheucticus melanocephalus & black-headed grosbeak & $x$ & $x$ \\
\hline Guiraca caerulea & blue grosbeak & $x$ & \\
\hline Passerina amoena & lazuli bunting & $x$ & \\
\hline Pipilo erythrophthalmus & rufous-sided towhee & $x$ & $x$ \\
\hline Zonotrichia leucaphrys & white-crowned sparrow & $x$ & $x$ \\
\hline Zonotrichia albicollis & white-throated sparrow & $x$ & $x$ \\
\hline Chondestes grammacus & lark sparrow & $x$ & \\
\hline Amphispiza bilineata & black-throated sparrow & & $x$ \\
\hline Spizella passerina & chipping sparrow & & $x$ \\
\hline Passerculus sandwichensis & savannah sparrow & $x$ & $x$ \\
\hline Melospiza melodia & song sparrow & $x$ & \\
\hline Juneo hyemalis & dark-eyed junco & $x$ & $x$ \\
\hline Sturnella neglecta & western meadowlark & $x$ & $x$ \\
\hline Agelaius phoeniceus & red-winged blackbird & $x$ & \\
\hline Euphagus cyanocephalus & Brewer's blackbird & $x$ & \\
\hline Molothrus after & brown-headed cowbird & $x$ & \\
\hline Quiscalus quiscula & common grackle & $x$ & \\
\hline lcterus galbula & northern oriole & $x$ & \\
\hline Carduelis tristis & American goldfinch & $x$ & \\
\hline Carduelis psaltria & lesser goldfinch & $x$ & \\
\hline Carpodacus mexicanus & house finch & $x$ & $x$ \\
\hline
\end{tabular}

Ref. TAC, 1993, 1992, 1990, 1988, 1986; DOE, 1983. 
Table 2.5 Mammals observed or expected to occur in the area of the Naturita site, Colorado

\begin{tabular}{|c|c|c|c|}
\hline \multirow[b]{2}{*}{ Scientific name } & \multirow[b]{2}{*}{ Common name } & \multicolumn{2}{|c|}{ Habitat } \\
\hline & & Riparian & Upland \\
\hline Sy/vilagus nuttallii & mountain cottontail & $\mathrm{x}$ & \\
\hline Sylvilagus audubonir ${ }^{a}$ & desert cottontail & & $x$ \\
\hline Lepus californicus ${ }^{a}$ & black-tailed jackrabbit & & $x$ \\
\hline Eutamias minimus ${ }^{a}$ & least chipmunk & & $x$ \\
\hline Ammospermophilus leucurus & $\begin{array}{l}\text { white-tailed antelope } \\
\text { ground squirrel }\end{array}$ & & $x$ \\
\hline Spermophilus richardsonii & Richardson's ground & & \\
\hline & squirrel & $x$ & $x$ \\
\hline Spermophilus variegatus & rock squirrel & & $x$ \\
\hline Cynomys leucurus & Gunnison prairie dog & & $x$ \\
\hline Thomomys talpoides & northern pocket gopher & $x$ & $x$ \\
\hline Perognathus flavus & silky pocket mouse & & $x$ \\
\hline Dipodomys ordii & Ord's kangaroo rat & $\mathrm{X}$ & $x$ \\
\hline Castor canadensis ${ }^{a}$ & beaver & $x$ & \\
\hline Peromyscus crinitus & canyon mouse & & $\mathrm{X}$ \\
\hline Peromyscus maniculatus & deer mouse & $x$ & $x$ \\
\hline Peromyscus truei & pinon mouse & & $x$ \\
\hline Onychomys leucogaster & northern grasshopper & & \\
\hline Neotoma lepida & mouse & & $x$ \\
\hline & desert woodrat & & $x$ \\
\hline Ondatra zibethicus & muskrat & $x$ & \\
\hline Zapus princeps & western jumping mouse & $x$ & \\
\hline Erethizon dorsatum & porcupine & $x$ & $x$ \\
\hline Canis latrans ${ }^{a}$ & coyote & $x$ & $x$ \\
\hline Urocyon cinereoargenteus & gray fox & $x$ & $x$ \\
\hline Procyon lotora & raccoon & $x$ & $x$ \\
\hline Mustela frenata & long-tailed weasel & $x$ & $x$ \\
\hline Mustela vison & $\operatorname{mink}$ & $x$ & \\
\hline Taxidea taxus & badger & $x$ & $x$ \\
\hline Spilogale gracilis ${ }^{a}$ & western spotted skunk & $x$ & $x$ \\
\hline Mephitis mephitis & striped skunk & $x$ & $x$ \\
\hline Felis rufus ${ }^{a}$ & bobcat & $x$ & $x$ \\
\hline Cervus elaphus ${ }^{a}$ & elk & & $x$ \\
\hline Odocoileus hemionus ${ }^{a}$ & mule deer & $x$ & $x$ \\
\hline
\end{tabular}

'Species or species' sign observed at or near the site.

Ref. TAC, 1990, 1988, 1986; DOE, 1983; Bernard and Brown, 1978. 


\subsection{THREATENED AND ENDANGERED SPECIES}

This section describes the status of the threatened and endangered species and other species of concern that may occur in the study area (Appendix A). The federally listed threatened and endangered species are the black-footed ferret (Mustela nigripes), bald eagle (Haliaeetus leucocephalus), Colorado squawfish (Ptychocheilus /ucius), bonytail chub (Gila elegans), humpback chub (Gila cypha), and razorback sucker (Xyrauchen texanus). The southwestern willow flycatcher was proposed for listing as an endangered species on July 23, 1993 (58 FR 39495). The federal candidate species are the flannelmouth sucker, roundtail chub, ferruginous hawk (Buteo regalis), loggerhead shrike (Lunius ludovicianus), northern goshawk (Accipiter gentilis), Columbian sharp-tailed grouse (Tympanuchus phasianellus columbianus), white-faced ibis (Plegadis chihn), and Paradox lupine (Lupinus crassus).

\subsection{MAMMALS}

The black-footed ferret is also listed as endangered by the state of Colorado. No critical habitat has been designated. The ferret, primarily nocturnal, is closely associated with prairie dogs throughout its range. The ferret preys on prairie dogs and uses the prairie dog burrows as shelter and den sites. Because of this close association, all active prairie dog colonies are considered potential black-footed ferret habitat (Clark et al., 1984). The potential for the black-footed ferret to occur at and adjacent to the Naturita processing site is low (Carruthers, 1986). No active prairie dog towns were observed during five surveys of the Naturita site (TAC, 1993, 1992, 1990, 1988, 1986). A small, active Gunnison prairie dog town was found in the northern portion of the Dry Flats disposal site in 1988 (TAC, 1988). The area of the Dry Flats disposal and Coke Oven borrow sites was surveyed for prairie dog towns again in 1993. As recommended by the FWS (Appendix A), a 0.5-mile (mi) $[0.8$ kilometer $(\mathrm{km})]$ radius around each site was surveyed, and two small Gunnison prairie dog towns were observed. One of these towns is the small town recorded in 1988 , and the other town is at the northwestern corner of the Coke Oven borrow site. Each town contained approximately 20 active burrows (TAC, 1993). Parts of each prairie dog town could be temporarily disturbed by remedial action activities; however, neither town is big enough to support the black-footed ferret.

\section{$3.2 \quad$ BIRDS}

The bald eagle is also listed as endangered by the state of Colorado. No critical habitat has been designated. The eagle is generally associated with river habitat where suitable perches and viable fisheries are available; large cottonwood trees are used for perching or roosting sites. The eagle feeds mainly on fish; however, carrion, waterfowl, and rabbits may also be consumed, especially during the winter (Woodward-Clyde, 1983). The bald eagle is a locally common winter resident along major rivers and is a rare breeder in western Colorado (CDM and Bio/West, 1983). It is not known to 
nest along the San Miguel River but does hunt along the river during the winter. In addition, a raptor survey conducted by the FWS in the areas of potential impact did not reveal any bald eagle nests (Opdycke, 1987). Although bald eagles have been seen perched in the cottonwoods in the riparian habitat, there are no known, regularly used roost sites along the river in the area of the Naturita processing site. The bald eagle density is generally low (approximately six) along the river in the processing site area, and use in the upland site areas is sporadic (Welch, 1993; Sherman, 1987; Carruthers, 1986). Two winter concentration areas are near the processing site. One is along the San Miguel River 5 to $6 \mathrm{mi}(8$ to $10 \mathrm{~km}$ ) northeast of the site, and the other is along the Dry Creek basin 5 to $6 \mathrm{mi}(8$ to $10 \mathrm{~km}$ ) south of the site (Welch, 1993). The remedial action activities would not affect these two winter concentration areas. Given that winter bald eagle use along the San Miguel River is light in the site area, that there will be two 4-month winter shutdowns of the remedial action, that there are no winter perch or roost sites at or near the site, and that there are numerous cottonwood stands along the river, remedial action activities are not expected to affect the bald eagle.

The willow flycatcher is widely distributed in the United States. There are four subspecies of the willow flycatcher, and the southwestern willow flycatcher (E.t. extimus) occurs in the southwestern United States. The northern boundary of the range of E.t. extimus has not been determined, although it is believed to be in the area of the New Mexico-Colorado state line. E.t. extimus intergrades with the northern subspecies, E.t. adostas. Primarily due to the destruction of riparian habitat, populations of E.t. extimus have declined precipitously, and 500 to 1000 pairs probably exist in the wild (Unitt, 1987). Therefore, the southwestern willow flycatcher has been proposed for listing as an endangered species (58 FR 39495).

The southwestern willow flycatcher generally nests in willows; in recent years, they have begun to nest in salt cedars. The preferred habitat in the southwest is riparian habitat along bodies of water, such as that which occurs along the San Miguel River (Unitt, 1987). Wildlife surveys of the riparian vegetation along the San Miguel River were conducted in June 1986. Two male willow flycatchers (subspecies not determined) were heard calling repeatedly (TAC, 1986). These birds were singing in the dense growth of cottonwoods and willows that grows in the western part of the former tailings area (Figure 3.1). It is possible that these birds were nesting because the willow flycatcher migration was essentially complete and migrating willow flycatchers rarely sing (Unitt, 1987). These observations took place before E.t. extimus was added to the federal candidate species list or proposed for listing by the FWS, so the information necessary to determine if the singing birds were E.t. extimus or E.t. adostas was not obtained. These subspecies are differentiated on the basis of color and wing measurements, which requires that the birds be trapped in mist nets, measured, and compared to published color charts. Field surveys for this species were conducted in June of 1990, 1991, 1993, and 1994 along the San Miguel River and Dry Creek (TAC, 1994, 1993, 1991, 1990). These surveys included approximately $3 \mathrm{mi}(5 \mathrm{~km})$ of the San Miguel River upstream and 


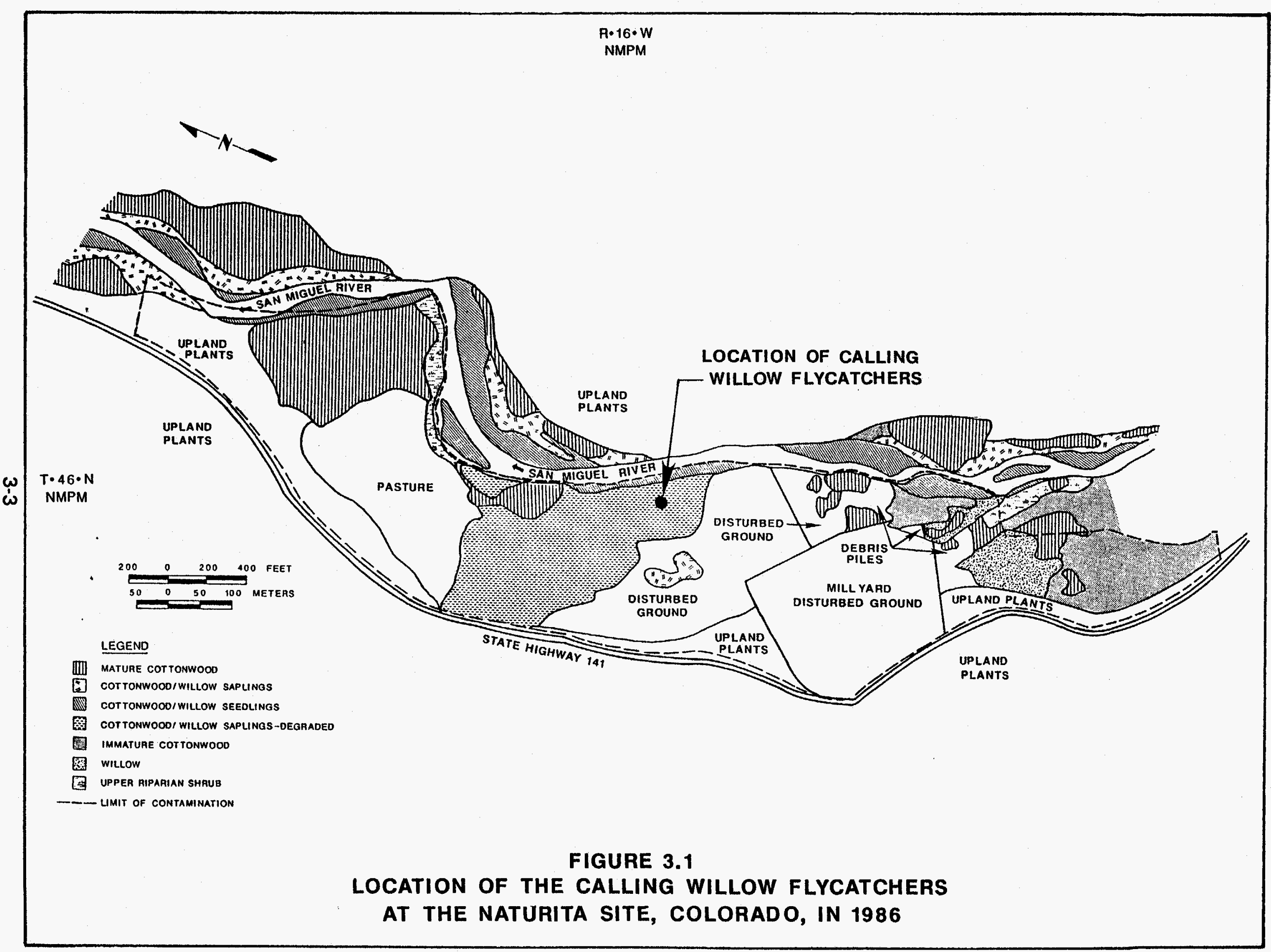


downstream of the Naturita site and $5 \mathrm{mi}(8 \mathrm{~km})$ of Dry Creek beginning at its confluence with the San Miguel River. The southwestern willow flycatcher was not heard or observed in the area of the Naturita site or along Dry Creek. It is not unusual for small, isolated populations of this species to disappear from an area for a year or two and then return (Unitt, 1987). In addition, habitat degradation caused by a die-off of willows and some other riparian plant species was observed in 1990 along the San Miguel River and Dry Creek (TAC, 1990). Drought conditions during the previous 2 years may have been the cause of this die-off.

Based on the surveys for E.t. extimus from 1990 through 1994, it was determined that this bird species does not currently nest along the San Miguel River or Dry Creek and that remedial action would not affect this species or jeopardize its continued existence. However, because potential habitat for this species occurs in the areas that could be affected by remedial action, surveys for this species would be conducted during remedial action. If these surveys resulted in the determination that E.t. extimus nests in areas that would be disturbed during remedial action, formal conferencing with the FWS would be initiated, and a mitigation plan would be prepared. This plan may include such measures as postponing or suspending remedial action in the area of concern until after the nesting season or trapping the birds and moving them.

The ferruginous hawk occurs in semiarid plains and intermountain areas of Colorado and other western states. This species typically nests in junipers, though it will nest on the ground or rock outcrops if tree nesting sites are not available (Schmutz, 1984; Perkins and Lindsey, 1983; Thurow and White, 1983; Smith and Murphy, 1982). Natural resources personnel familiar with the Naturita site indicate that the ferruginous hawk is occasionally seen in the area (Blymer, 1987); however, ground surveys in the area failed to document the occurrence of this species (TAC, 1993, 1992, 1991, 1990, 1988, 1986; DOE, 1983). In addition, the FWS conducted an aerial survey during the 1986 nesting season, and the ferruginous hawk was not observed (Opdycke, 1987). This analysis indicates that this species does not nest at or near the Naturita processing, Dry Flats disposal, and Coke Oven borrow sites. Furthermore, it is doubtful that this species has occurred at the sites during recent years except for an occasional migrant; therefore, remedial action activities would not affect the ferruginous hawk.

The white-faced ibis breeds in colonies in freshwater marshes from eastern Oregon sporadically across to North Dakota and south into parts of Kansas and Colorado. It winters in the southwestern United States and Mexico

(Armbruster, 1983). In western Colorado, the white-faced ibis occurs as an uncommon to common migrant in aquatic and agricultural habitats (Kingery and Graul, 1978). Wildlife surveys of the riparian habitat along the San Miguel River in the area of the processing site and along Dry Creek in the area of the Coke Oven borrow site failed to detect the presence of the white-faced ibis (TAC, 1993, 1992, 1991, 1990, 1988, 1986). Therefore, remedial action activities would not affect the white-faced ibis. 
The loggerhead shrike occurs as a breeding species throughout most of Colorado, including the Naturita site area (Kingery and Graul, 1978). It prefers open country with patches of trees and shrubs, and, in Colorado, nests in desert shrub, short-grass prairie, agricultural lands, and riparian areas (FWS, 1992; Kingery and Graul, 1978). Historically, this species was considered a common to fairly common breeding species in Colorado (Kingery and Graul, 1978) and nearby Utah (Cook, 1984); however, this species has declined steadily over most of its range, including Colorado, in recent years (Robbins et al., 1986; Ehrlich et al., 1988). The loggerhead shrike nests in sagebrush and riparian plant communities, both of which occur at the Naturita site. Wildlife surveys have been conducted at the Naturita site over the last 10 years, and the loggerhead shrike has never been observed (TAC, 1993, 1992, 1991, 1990, 1988, and 1986; DOE, 1983). It is very unlikely that this species has occurred or will occur at or near the Naturita site; therefore, the remedial action would not impact the loggerhead shrike.

The northern goshawk is a year-round resident in northwest Colorado (Kingery and Graul, 1978). In the west, this species nests in mature conifer forests such as those dominated by Douglas fir and ponderosa pine (Call, 1978; Moore and Henny, 1983). The remedial action activities would not take place in conifer woods except for a small amount of pinon-juniper woods at the Dry Flats disposal site; therefore, the remedial action would not impact the northern goshawk.

The Columbian sharp-tailed grouse has been reduced to remnant populations in most of its range and has been extirpated from Oregon, California, and Nevada (Marks and Marks, 1988). Historically, this species occurred in wooded terrain in the Naturita area (Rogers, 1969). In recent years, population levels of the Columbian sharp-tailed grouse have declined because of habitat destruction due to coal strip mining, agriculture, and home site development (Giesen, 1981). Information on the Columbian sharp-tailed grouse indicates that it uses mountain shrub and wooded riparian habitats in the winter (Marks and Marks, 1988), and studies of Columbian sharp-tailed grouse habitat use in Moffat County. Colorado, indicated that this species selected mountain shrub habitat (Giesen, 1987). Based on the historic range of the Columbian sharp-tailed grouse and its preference for mountain shrub habitat, which does not occur at the Naturita site, it is likely that the species does not occur in the Naturita area. Therefore, the remedial action activities would not affect the Columbian sharp-tailed grouse.

\subsection{FISH}

The Colorado squawfish is also listed as endangered by the state of Colorado. This fish is the largest minnow in North America. Its historical range includes the Colorado River and all of the larger tributaries from Wyoming to the Gulf of California, such as the San Miguel River. The Colorado squawfish is now rare and limited to the upper Colorado River basin (Valdez et al., 1982). Although the Colorado squawfish historically occurred in the San Miguel River, its relative 
abundance was rare, as reported by Nolting (1957). Currently, the squawfish does not occur in the San Miguel River, and it is unlikely that this river meets the habitat requirements of this fish (Carruthers, 1986).

The bonytail and humpback chubs are also listed as endangered by the state of Colorado. These fishes were historically distributed throughout the Colorado River basin in main river channels and larger tributaries. The bonytail chub was most common in the open river area of large river channels, while the humpback chub was restricted to swift, deep water areas, mainly in canyons. Historically, the bonytail chub was reported to be abundant in the San Miguel River (Nolting, 1957). The humpback chub may have also occurred in the San Miguel River. Currently, neither chub species occurs in the San Miguel River, and it is unlikely that the river meets the habitat requirements of these fishes (Carruthers, 1986).

The razorback sucker originally occupied $1500 \mathrm{mi}(2414 \mathrm{~km})$ of the Colorado River system. Its current distribution is limited to $600 \mathrm{mi}(965 \mathrm{~km})$, mostly in the upper river basin. All specimens of this fish collected in the upper Colorado River were adults, which suggests a low reproductive rate. Although the habitat preference of this species has not been fully evaluated due to the small number of observations, it appears to prefer backwaters and gravel pits with little or no flow and silt bottoms (Valdez et al., 1982). The razorback sucker may have occurred in the San Miguel River. However, this river is not currently occupied by the razorback sucker, and it is unlikely that the river meets the habitat requirements of this fish (Carruthers, 1986).

Endangered fish species do not occur in the San Miguel River, so remedial action would not have a direct impact on these species. However, remedial action at the Naturita site may have an indirect impact on the endangered fish species. The FWS determined that an upper Colorado basin-wide (which includes the San Miguel River) jeopardy situation has existed since 1978 for the four fish species discussed above (FWS, 1987). Depletion of water within the basin, which includes water required for remedial action, would have a negative impact on these species and would result in a "may affect" determination by the FWS. This determination requires the initiation of formal conferencing with the FWS under the Endangered Species Act. According to the "Recovery Implementation Program for Endangered Fish Species in the Upper Colorado River Basin" (FWS, 1987), water depletion subject to a "may affect" determination would require a one-time contribution to the FWS of a dollar amount per acre-foot of water used based on the average annual water depletion caused by a project. Water from the San Miguel River would be used for the remedial action (e.g., for dust control and equipment washing), and it is estimated that the average annual water requirement for the Dry Flats disposal alternative would be 86 acre-feet. Therefore, this water use would be subject to the one-time monetary contribution to the FWS.

The FWS has designated $2096 \mathrm{mi}(3369 \mathrm{~km})$ of the Colorado River and its tributaries as critical habitat for the endangered fish species. Therefore, the 
withdrawal of water from the San Miguel River for the remedial action would be "an adverse modification of this critical habitat" that would require formal conferencing with the FWS (refer to the FWS letter dated April 20, 1993, in Appendix $A$ of this attachment). The request for formal conferencing for the adverse modification of critical habitat could be made in the same letter requesting formal conferencing for the "may affect" determination. Mitigation for the adverse modification of critical habitat would be accomplished with the mitigation for the "may affect" determination.

The flannelmouth sucker and roundtail chub are indigenous fish of the San Miguel River (CDOW, 1977) and likely occur in the river in the area of the Naturita site. These species have been declining in the lower Colorado River Basin, including the San Miguel River (Nesler, 1992). Remedial action would involve the cleanup of 47 ac (19 ha) of contaminated materials within the 100-year floodplain of the San Miguel River. This activity would have the potential to impact the San Miguel River, including the flannelmouth sucker and roundtail chub. Potential impacts to the river would be reduced by not performing remedial action in the river, recontouring and revegetating cleared areas as soon as possible, and providing erosion control measures such as mulch or berms where needed. In addition, a buffer zone between the river and work areas may be left. In most areas, this buffer zone would contain contaminated materials, and an application for supplemental standards would have to be approved by the NRC and state of Colorado. This supplemental standards application would have to show that leaving the contaminated materials in place is protective of human health and the environment. During the remedial action, measures would be taken to protect the water quality of the San Miguel River, and it is possible that supplemental standards would be applied to contaminated areas along the river. Therefore, it would be unlikely that the remedial action would affect these endangered fish species.

\subsection{PLANTS}

The Paradox lupine is also listed by the state of Colorado as a species of concern. The lupine is a perennial plant with white flowers and narrow leaflets that forms dense mats and flowers in early to late May. The lupine occurs in draws and washes with sparse vegetation between 5000 and $5800 \mathrm{ft}$ $(1524$ and $1768 \mathrm{~m})$ in elevation in the pinon-juniper woodland and sagebrush vegetation types. It grows on clay soils derived from the Mancos Shale Formation in the Naturita-Nucla area (Peterson, 1983; Payson, 1915). The lupine has been found in six locations in Montrose County, Colorado. In the Paradox Valley area, it is found on Quaternary alluvium of the Chinle Formation; in the Naturita area, it occurs on clayey soils of the Mancos Shale Formation. The closest locations to the Naturita site are 1 and $3 \mathrm{mi}(2$ and $5 \mathrm{~km})$ to the northeast across the San Miguel River and to the east, respectively (Peterson, 1983). The lupine is not expected to occur at the Naturita site because soils of the Chinle and Mancos Shale Formations are not present. However, surveys for this species were conducted in the area of the Dry Flats disposal and Coke Oven borrow sites. The results of these surveys indicate 
ATTACHMENT 2

BIOLOGICAL ASSESSMENT

THREATENED AND ENDANGERED SPECIES

that this species does not occur at or near any of the sites that were surveyed (Rose, 1990; Anderson, 1989). 


\subsection{REFERENCES}

Aldon, E. F., 1981. "Long-Term Plant Survival and Density Data from Reclaimed Southwestern Coal Mine Spoils," in The Great Basin Naturalist, Vol. 51, No. 3, pp. 271-273.

Anderson, John, 1989. U.S. Fish and Wildlife Service, Grand Junction, Colorado, personal communication to Charles Burt, Jacobs Engineering Group Inc., Albuquerque, New Mexico, January 31, 1989.

Armbruster, J. S., ed., 1983. "Impact of Coal Surface Mining on 25 Migratory Bird Species of High Federal Interest," U.S. Fish and Wildlife Service, FWS/OBS-83/35, Fort Collins, Colorado.

Bernard, S. R., and K. F. Brown, 1978. "Distribution of Mammals, Reptiles, and Amphibians by BLM Physiographic Regions and A. W. Kuchler's Associations for the Eleven Western States," U.S. Department of the Interior, Bureau of Land Management, Denver, Colorado.

Blymer, Mike, 1987. Uncompahgre Basin Resource Area, U.S. Bureau of Land Management, Montrose, Colorado, personal communication to Eloise Mulford, Jacobs Engineering Group Inc., Albuquerque, New Mexico, February 20, 1987.

Call, M. W., 1978. "Nesting Habitats and Surveying Techniques for Common Western Raptors," Bureau of Land Management, Technical Note TN-316. Denver, Colorado.

Carruthers, Robert V., 1986. Uncompahgre Basin Resource Area, U.S. Bureau of Land Management, Montrose, Colorado, personal communication to Charles Burt, Jacobs Engineering Group Inc., Albuquerque, New Mexico, March 27, 1986.

CDM and Bio/West (Camp, Dresser, \& McKee, Inc. and Bio/West, Inc.), 1983. Biological Assessment Report, Pacific Shale Project, Wheat Ridge, Colorado, and Logan, Utah.

CDOW (Colorado Division of Wildlife), 1977. "San Miguel River \#1 (Fisheries Survey of the San Miguel River)," Code No. 46842, CDOW, Montrose, Colorado.

Clark et al. (T. W. Clark, T. M. Campbell, M. H. Schroeder, and L. Richardson), 1984. "Handbook of Methods for Locating Black-Footed Ferrets," U.S. Bureau of Land Management, Wildlife Technical Bulletin No. 1, Cheyenne, Wyoming.

Cook, A. G., 1984. "Birds of the Desert Region of Uinta County, Utah," Great Basin Naturalist, Vol. 44, No. 4, pp. 584-620.

DOE (U.S. Department of Energy), 1983. "Environmental Assessment of Remedial Actions on the Uranium Mill Tailings at the Naturita site, Montrose County, Colorado," unpublished report, DOE UMTRA Project Office, Albuquerque Operations Office, Albuquerque, New Mexico. 
Ehrlich et al. (P. R. Ehrlich, D. S. Dobkin, and D. Wheye), 1988. The Birders Handbook, Simon and Schuster, Inc., New York.

Evans et al., 1978. (A. K. Evans, E. W. Uhleman, and P. A. Eby), 1978. Atlas of Western Surface-Mined Lands: Coal, Uranium, and Phosphate, U.S. Fish and Wildlife Service, FWS/OBS-78/20, Fort Collins, Colorado.

FWS (Fish and Wildlife Service), 1992. "Loggerhead Shrike, Lunius ludovicianus," FWS, Bismarck, North Dakota.

FWS (Fish and Wildlife Service), 1987. "Recovery Implementation Program for Endangered Fish Species in the Upper Colorado River Basin," FWS, Region 6, Denver, Colorado.

Giesen, K. M., 1987. "Population Characteristics and Habitat Use by Columbian SharpTailed Grouse in Northwest Colorado," Colorado Division of Wildlife, Wildlife Research Report 01-03-045 (W-37-R), Fort Collins, Colorado.

Giesen, K. M., 1981. "Distribution and Status of Mountain Sharp-Tailed Grouse," Colorado Division of Wildlife, Wildlife Research Report W-37-R-34, Fort Collins, Colorado.

Hammerson, G. A., 1986. Amphibians and Reptiles in Colorado, Colorado Division of Wildlife, Department of Natural Resources, Denver, Colorado.

Jacobsen, K., 1992. U.S. Army Corps of Engineers, Grand Junction, Colorado, personal communication to Charles Burt, Jacobs Engineering Group Inc., Albuquerque, New Mexico, October 5, 1992.

Kingery, H. E., and W. D. Graul, ed., 1978. Colorado Bird Distribution Latilong Study, prepared by the Colorado Field Ornithologists, Denver, Colorado, for Colorado Division of Wildlife, Denver, Colorado.

Kuchler, A. W., 1975. "Potential Natural Vegetation of the Conterminous United States," American Geographic Society Special Publication No. 36, New York, New York (Map).

Leachman, Bob, 1990. U.S. Fish and Wildlife Service, Grand Junction, Colorado, personal communication to Charles Burt, Jacobs Engineering Group Inc., Albuquerque, New Mexico, March 5, 1990.

Marks, J. S., and V. S. Marks, 1988. "Winter Habitat Use by Columbian Sharp-Tailed Grouse in Western Idaho," in Journal of Wildlife Management, Vol. 52, No. 4, pp. 743-746.

Moore, K. R., and C. J. Henny, 1983. "Nest Site Characteristics of Three Coexisting Accipiter Hawks in Northeastern Oregon", Raptor Research, Volume 17, Number 3. pp. 65-76. 
Nesler, T., 1992. Colorado Division of Wildlife, Fort Collins, Colorado, personal communication to Charles Burt, Jacobs Engineering Group Inc., Albuquerque, New Mexico, October 19, 1992.

Nolting, D. R., 1957. "The Effects of Uranium Mill Waste Disposal on the Fish Populations and Aquatic Productivity of the Lower San Miguel and Dolores Rivers," Colorado Department of Game and Fish, Montrose, Colorado.

Opdycke, Jeffrey D., 1987. U.S. Fish and Wildlife Service, Grand Junction, Colorado, personal communication to John Themelis, U.S. Department of Energy, UMTRA Project Office, Albuquerque Operations Office, Albuquerque, New Mexico, January $13,1987$.

Payson, E., 1915. "New and Noteworthy Plants from Southwestern Colorado," in Botanical Gazette, Vol. VI, pp. 374-376.

Perkins, M. W., and W. J. Lindsey, 1983. "Nesting Studies of Ferruginous Hawks in the Ely BLM District, Nevada," in North American Bird Bander, Vol. 8, No. 3, pp. 106-107.

Peterson, J. S., 1983. "Status Report for Lupinus crassus Payson," Colorado Natural Areas Program, Denver, Colorado.

Richardson et al. (B. Z. Richardson, S. B. Monsen, and D. M. Bowers), 1986. "Interseeding Selected Shrubs and Herbs on Mine Disturbances in Southeastern Idaho," in Proceedings - Symposium on the Biology of Artemesia and Chrysothamnus, U.S. Forest Service, Intermountain Research Station, General Technical Report INT-200, Ogden, Utah.

Ricklefs, R. E., 1979. Ecology, Second Edition, Chiron Press, New York, New York.

Robbins et al. (C. S. Robbins, D. Bystrak, and P. H. Geissler), 1986. "The Breeding Bird Survey: Its First Fifteen Years, 1965-1979," U.S. Fish and Wildlife Services Resource Publication 157, Washington, D.C.

Rogers, G. E., 1969. "The Sharp-Tailed Grouse in Colorado," Colorado Game, Fish, and Parks, Technical Publication 23, Denver, Colorado.

Rose, Keith L., 1990. U.S. Fish and Wildlife Service, Golden, Colorado, personal communication to Charles Burt, Jacobs Engineering Group Inc., Albuquerque, New Mexico, August 9, 1990.

Schmutz, J. K., 1984. "Ferruginous and Swainson's Hawk Abundance and Distribution in Relation to Land Use in Southeastern Alberta," in Journal of Wildlife Management, Vol. 48, No. 4, pp. 1180-1187. 
Sherman, Rick, 1987. Colorado Division of Wildlife, Montrose, Colorado, personal communication to Eloise Mulford, Jacobs Engineering Group Inc., Albuquerque, New Mexico, March 2, 1987.

Smith, D. G., and J. R. Murphy, 1982. "Nest Site Selection in Raptor Communities of the Eastern Great Basin Desert," in Great Basin Naturalist, Vol. 42, No. 3, pp. 395-404.

Swenson, E. A., and C. L. Mullins, 1985. "Revegetating Riparian Trees in Southwestern Floodplains," in Riparian Ecosystems and Their Management: Reconciling Conflicting Use, U.S. Forest Service, Rocky Mountain Forest and Range Experiment Station, General Technical Report RM-120, Fort Collins, Colorado.

TAC (Technical Assistance Contractor), 1994. "Unpublished Field Notes, Naturita, Colorado, Uranium Mill Tailings Site," June 13 through 17, 1994, prepared by the TAC, Albuquerque, New Mexico, for the U.S. Department of Energy, UMTRA Project Office, Albuquerque Operations Office, Albuquerque, New Mexico.

TAC (Technical Assistance Contractor), 1993. "Unpublished Field Notes, Naturita, Colorado, Uranium Mill Tailings Site," June 29 through July 1, 1993, prepared by the TAC, Albuquerque, New Mexico, for the U.S. Department of Energy, UMTRA Project Office, Albuquerque Operations Office, Albuquerque, New Mexico.

TAC (Technical Assistance Contractor), 1992. "Unpublished Field Notes, Naturita, Colorado, Uranium Mill Tailings Site," September 29, 1992, prepared by the TAC, Albuquerque, New Mexico, for the U.S. Department of Energy, UMTRA Project Office, Albuquerque Operations Office, Albuquerque, New Mexico.

TAC (Technical Assistance Contractor), 1991. "Unpublished Field Notes, Naturita, Colorado, Uranium Mill Tailings Site," June 18 through 21, 1991, prepared by the TAC, Albuquerque, New Mexico, for the U.S. Department of Energy, UMTRA Project Office, Albuquerque Operations Office, Albuquerque, New Mexico.

TAC (Technical Assistance Contractor), 1990. "Unpublished Field Report, Naturita, Colorado, UMTRA Project Site," June 11 through 14, 1990, prepared by the TAC, Albuquerque, New Mexico, for the U.S. Department of Energy, UMTRA Project Office, Albuquerque Operations Office, Albuquerque, New Mexico.

TAC (Technical Assistance Contractor), 1988. "Unpublished Field Notes, Naturita, Colorado, Uranium Mill Tailings Site," November 3, 1988, prepared by the TAC, Albuquerque, New Mexico, for the U.S. Department of Energy, UMTRA Project Office, Albuquerque Operations Office, Albuquerque, New Mexico.

TAC (Technical Assistance Contractor), 1986. "Unpublished Field Notes, Naturita, Colorado, Uranium Mill Tailings Site," June 9 and 11, 1986, prepared by the TAC, Albuquerque, New Mexico, for the U.S. Department of Energy, UMTRA Project Office, Albuquerque Operations Office, Albuquerque, New Mexico. 
Thurow, T. L., and C. M. White, 1983. "Nest Site Relationship Between the Ferruginous Hawk and Swainson's Hawk," in Journal of Field Ornithology, Vol. 54, No. 4, pp. 395-405.

Unitt, P., 1987. "Empidonax traillii extimus: An Endangered Subspecies," in Western Birds, 18:137-162.

Valdez et al. (R. Valdez, P. Mangan, R. Smith, and B. Nilson), 1982. Upper Colorado River Investigation, Rifle, Colorado to Lake Powell, Utah, U.S. Fish and Wildlife Service, Colorado River Fishery Project, Grand Junction, Colorado.

Wagner et al. (W. L. Wagner, W. C. Martin, and E. F. Aldon), 1978. "Natural Succession on Strip-Mined Lands in Northwestern New Mexico," in Reclamation Review, Vol. 1, pp. 67-73.

Welch, Robert, 1993. Uncompahgre Basin Resource Area, Bureau of Land Management, Montrose, Colorado, personal communication to Charles Burt, Jacobs Engineering Group Inc., Albuquerque, New Mexico, May 27, 1993.

Woodward-Clyde (Woodward-Clyde Consultants), 1983. Biological Assessment for Clear Creek Shale Oil Project, Englewood, Colorado.

York, J. C., 1985. "Dormant Stub Planting Techniques," in Riparian Ecosystems and Their Management: Reconciling Conflicting Uses, U.S. Forest Service, Rocky Mountain Forest and Range Experiment Station, General Technical Report RM-120, Fort Collins, Colorado.

\section{FEDERAL REGISTER}

58 FR 39495, "Endangered and Threatened Wildlife and Plants; Proposed Rule to List the Southwestern Willow Flycatcher as Endangered With Critical Habitat," July 23, 1993, Federal Register, Office of the Federal Register, National Archives and Records Administration, Washington, D.C. 
APPENDIX A

CORRESPONDENCE WITH THE FISH AND WILDLIFE SERVICE 


\title{
United States Department of the Interior
}

\author{
FISH AND KTLDLIFE SERVICE \\ ENDANGERED SPECIES OFFICE \\ II 25' \\ DNDEPNDENCE PLAZA \\ SUTTE B-113 \\ GRAYD JUNCTION, COLORADO BISOS \\ TELEPHONE: $300-241-0563$
}

IN RerLY Rere TO:

February 27, 1986

Mr. Dave Lechel

Manager, Environmental Services

Jacobs Engineering Group. Inc.

5301 Central Avenue N.W.. Suite 1700

Albuquerque, N.M. 87108

Dear Mr. Lechel:

We bave received your letter of January 22, 1986, regarding Uranium Mill Tailings Remedial Action (UMTRA) Project plans of Department of Energy for clean-up of uranium tailing sites pear Naturita, Montrose County, Colorado, and pear Slickrock, San Miguel County, Colorado.

We are furnishing you with the following list of rare species which bay be present witbin the area of influence of your project. The lists pertain to both sites with the exception noted below:

\section{Federally Listed Species}

\begin{abstract}
Bald eagle Black-footed ferret Bonytail chub Colorado squawfish Lumpback chub Peregrine falcon
\end{abstract}

Belieeetus leucocephalus

Mustela nixripes

Gile elerans

Ptychocheilus lucius

Gila cyphe

Felco perestinus (Slickrock site only)

Historically, the endangered black-footed ferret (Mustela nigripes) aay have occurred in portio's of southwestern Colorado. Although unconfirmed sight ings of this ramal have occurred in northwestern Colorado, the only known population is in Meeteetse, Hyoniog. Literature docunents a close association between prairie dogs and black-footed ferrets. The standard that is used for deternining possible project effects to bleck-footed ferrets is the disturbance of currently occupied prairie dos habitst. should any of the activities that are part of the above-referenced project result in an impect to prairie dogs, black-footed ferret surveys may be necessary.

If water quality in the Colorado River will be affected by project activities, or if remedial action of any kind results in the consumptive use of water from the upper Colorado River basin, then resulting impacts to the Colorado squawfish (Ptychocheilus lucius), bumpbeck chub (Gile cypha), and bonytail chub (Gile elerans) sust be addressed in your assessment of impects. 
The lead Federal agency for Endangered Species Act (ESA) Section 7

consultation should review their proposed Federal action and determine if the action would affect any listed species. If the deterwination is "may affect" for listed species, the Federal agency must request in writing formal consultation from the Field Supervisor, U.S. Fish and Wildlife Service, Endangered Species Office, 2078 Administration Building, 1745 West 1700 South, Salt Lake City, Utah 84104. At this time, this agency should provide this office a biological assessent and/or any other relevant information was used in making the impact determinations.

We would like to bring to your attention species which are candidates for official listing as threatened or endangered species (Federal Register, Vol. 47. No. 251, December 30, 1982, and Vol. 50, No. 188, September 27, 1985). While these species have no legal protection at present under the Endangered Species Act, they are quite rare and restricted. We believe that it is within the spirit of the ESA to consider project impacts to candidate species at this tine. Additionally, we wish to ane you sware of the presence of Federal candidates shoujd any be proposed or listed prior to the time that all Federal actions related to the project are complete.

\section{Federal Candidate Species}

Ferruginous hawk Grand Junction milkvetch Long billed curlew Paradox lupióne Razorback sucker Swainson's hawk White-faced ibis
Buteo rerlais Astraxelus linifolius Numenius americanus

Lupinus paradox Xyrauchen texanus Buteo Ewainsoni Pleradis chihi

The Paradox lupine is known to occur at one of the Naturita sites. Our staff botanist has recently visited the site and confirmed the presence of this rare plant.

We appreciate your interest in cosserving endangered species. If you require further information on listed species, please contact John Anderson of our Grand Junction, Colorado of fice, telephone 303-241-0563.

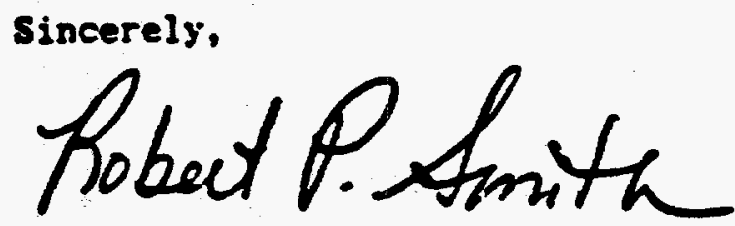

Robert P. Smith

Project Leader 


\section{United States Department of the Interior}

FISH AND WILDLIFE SERVICE

FISH AND WILDLIFE ENHANCEMENT

COLORADO STATE OFFICE

529 25 's Rond, Suite B-113

GRAND JUNCTION, COLORADO 82005

(303) $243-2778$

(FWE)

May 26. 1988

Bill Glover

Manager. Environmental Services

Jacobs Engineering Group. Inc.

5301 Central Avenue N.E.. Suite 1700

Albuquerque, NM 87108

Dear Mr. Glover.

This responds to your April 25, 1988, letter regarding the Uranium Mill Tailings Remedial Action Project at Naturita, Colorado. It appears that federally listed species may occur within the area of influence of the proposal.

\section{Federally Listed Species}

Black-footed ferret
Bald eagle
Colorado squawfish
Humpback chub
Bonytail chub

Black-footed ferret

Baid eagle

Humpback chub

Bonytail chub
Mustelo niaripes

Haliaeetus leucocephalus

Ptychocheilus lucius

Gila cyphe

Gila elegans

Historically, the black-footed ferret was belfeved to occur in portions of the construction work area. Literature documents a close association between prairie dogs and black-footed ferrets. Your pre-construction surveys should determine whether your activities will disturb prairie dog colonies. If so, black-footed ferret surveys may be required.

Wintering bald eagles are cormon throughout colorado and are primarily associated with streans and reservolrs. Project evaluation should determine whether bald eagles occur in the project area and whether impacts will occur to this endangered bird.

None of the federally listed fish species occur in the project area. However, we believe it is appropriate at this time to consider whether the proposed project will result in a depletion of water from the upper Colorado River basin. If so, formal consultation under the Endangered Species Act will be necessary.

The paradox lupine (Lupinus crassus) is a candidate for federal listing and may occur in the project area. While this plant currently receives no protection from the Endangered Species Act, we believe it is within the spirit of the act to consider potential impacts to this plant at this time. 
Section (7c) of the Endangered Species Act requires that the Federal agency proposing a major Federal action significantly affecting the quality of the human environment to conduct and submit to the Service a biological assessment to determine effects of the proposal on listed species. The biological assessment shall be completed within 180 days after the date on which initiated or a time mitually agreed upon between the agency and the Service. The assessment must be completed before physical project modification/alteration begins. If the biological assessment is not begun within 90 days, the species list above should be verified prior to initiation of the assessment.

The lead Federal agency should evaluate the potential impacts of the proposed project and determine if the action may affect any listed species. If a determination is "may affect" for listed species, the Federal agency must request in writing formal consultation from this office and should provide this office with a biological assessment, and any other relevant information used in making impact determinations.

The Fish and Wildife Service can enter into formal Section 7 consultation only with another federal agency or its designee. State, county, or other governmental or private organizations can participate in the consultation process, heip prepare information such as the biological assessment. participate in meetings, etc

The fish and Wildlife Service (Service) regards wetlands and riparian habitats as an important resource, due to their high value for fish and wildlife. On January 13, 1987, we provided Mr. Themelis with a wetland inventory of the Naturita site. These wetlands were defined according to "Classification of Wet lands and Deepwater Habitats of the United States" (Cowardin, et al.. 1977). We recormend that any adverse impacts to wetlands and riparian areas within the project influence be avoided.

If the Service can be of assistance to you in the future please contact this office.

Sincerely,

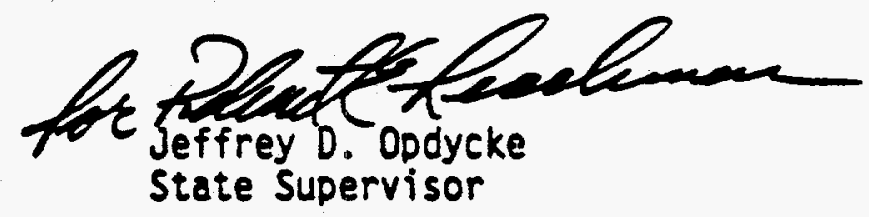

CC: FWS/FWE: SLC Official file Reading file

RELEACHMAN: cjharris Natdoe 
IN Reply Retax TO:

\section{United States Department of the Interior \\ FISH AND WILDLIFE SERVICE \\ COLORADO FIELD OFFICE \\ 730 SIMMS STREET \\ ROOM 292 \\ COLDEN. COLORADO 80401}

(FWE)

December 28, 1988

Charles J. Burt

Environmental Specialist

Jacobs Engineering Group. Inc.

5301 Central Avenue N.E. Suite 1700

Alburquerque, New Mexico 87108

Dear Mr. Burt:

This responds to your November 21,1988 , letter requesting an update of Federally listed species that may be associated with the proposed Uranium Mill-tailings Remedial Action Projects at Slickrock, Naturita, Gunnison and Maybell. Colorado.

We have reviewed the lists provided to Jacobs Engineering. Inc. In 1986 and 1988. The following changes should be made:

1) Naturita site - Delete the Grand Junction milkvetch.

2) Maybell site - Delete the White River penstemon. Add the bonytail chub.

3) Gunnison site - Add the Colorado squawfish, humpback chub. and bonytail chub.

The list for the slickrock site needs no changes.

We appreciate the opportunity to update the species lists for these actions. Please contact Bob Leachman of our Grand Junction office at (303) 243-2773 if there are any questions.

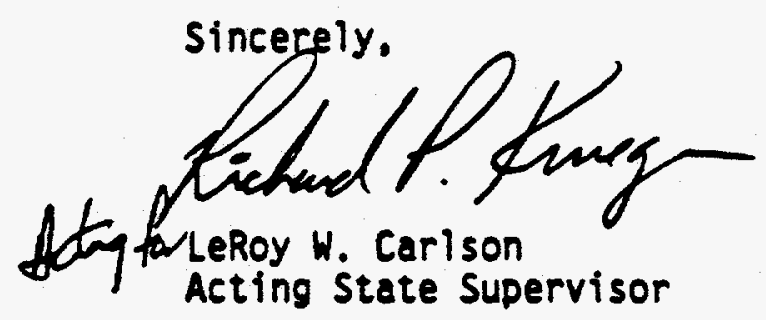

CC: FWS/FWE, Salt Lake City

Official File

Reading File 


\section{UNITED STATES DEPARTMENT OF THE INTERIOR \\ FISH AND WLDLIFE SERVICE \\ FISH AND WILDLIFE ENHANCEMENT \\ Western Colorado Sub-Olfice \\ $52925 \div$ Road, Suite B-113 \\ Grand Junction, CO 81505-6199 \\ FTS 332-0351 \\ COMM (303) 243-2778}

IN REPLY REFER TO:

FWE/CO:DOE:UMTRA:Maybell

Mail Stop 65412 Grand Junction

December 4, 1990

Mr. Mark L. Matthews

Project Manager

Uranium Mill Tailings Remedial Action Project Office

Department of Energy

P.O. Box 5400

Albuquerque, New Mexico 87115

Dear Mr. Matthews:

This responds to your October 4, 1990 and October 16, 1990, letters forwarding Environmental and Biological Assessments for the Maybell and Naturita Remedial Action Projects. Both projects are in Colorado. Our comments for each project are below.

\section{Mavbell Uranium Mill Tailings Site}

This office provided you a draft biological opinion dated November 13, 1990, for remedial action at Maybell, Colorado. This opinion was in response to your October 16 letter to Mr. Lee Carlson of our Golden, Colorado office. We have no further requirements for the Maybell site. We will finalize our draft biological opinion within $\mathbf{3 0}$ days of receipt of acknowledgement that the recommended depletion payment has been made to the National Fish and Wildlife Foundation.

Naturita Uranium Mill Tailings Site

\section{Biological Assessment}

We concur with the biological assessment's conclusion that the proposed project "may affect" federally listed fish. Formal consultation under the Endangered Species Act will, therefore, be required for this project.

We have discussed prairie dog distribution with the Bureau of Land Management in Montrose. It appears that more than 250 acres of prairie dogs may occur within 4.5 
miles of the project site. We suggest you coordinate with the Bureau to ensure your conclusion agrees with their information. Based on the most recent information we have, western Montrose County is occupied by the Gunnisons prairie dog (Cynomys gunnisoni) rather than the white-tailed prairie dog (Cynomys leucurus). This change should be made where appropriate unless your field observations or literature search concludes otherwise.

We appreciate the information you have provided regarding the southwestern willow flycatcher. We have alerted Dr. Jim Sedgewick with the Fish and Wildlife Service's National Ecology Research Center in Fort Collins regarding your proposed surveys. Dr. Sedgewick has conducted extensive research on this species and may be able to assist with the surveys proposed for 1991. He may be reached at FTS 323-5466.

\section{Floodplains and Wetlands Assessment}

We endorse your commitment to restore the wetland that will be effected during project construction. We will anticipate an opportunity to review the proposed revegetation/restoration plan during further coordination.

We have no further comments on the documents sent for our review. Please contact Bob Leachman if there are any questions.

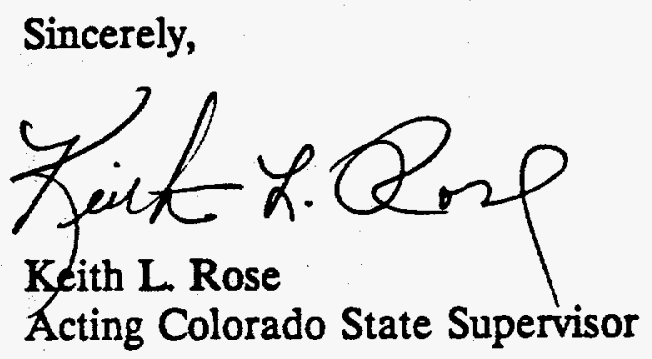

cc: FWS/FWE, Golden

FWS/FWE, Salt Lake City CDOW, Montrose 


$$
\text { DOI/umt/1290-0023 }
$$

\section{UNITED STATES DEPARTMENT OF THE INTERIOR FISH AND WILDLIFE SERVICE \\ FISH AND WILDLIFE ENHANCEMENT \\ Western Colorado Sub-Omice \\ 52925 r Road, Suite B-113 \\ Grand Junction, CO 81505-6199 \\ FTS 332-0351 \\ COMM (303) 243-2778}

IN REPLY REFER TO: FWE/GJ-6-CO-90-F-13

December 11, 1990

Mr. Mark L. Matthews, Project Manager

Uranium Mill Tailings Remedial Action Project Office

Department of Energy

Albuquerque Operations Office

P.O. Box 5400

Albuquerque, NM 87115

Subject: Biological Opinion Regarding Remedial Action at the Naturita, Colorado, Uranium Mill Tailings Site

This responds to your October 1, 1990, letter initiating Section 7 consultation under the Endangered Species Act of 1973, as amended. The Fish and Wildlife Service (Service) has reviewed your biological assessment and concurs with your "may affect" determination for Colorado squawfish (Ptychocheilus lucius), humpback chub (Gila cypha), and bonytail chub (Gila elegans), which are all federally listed as endangered. The fourth species addressed in your biological assessment, the razorback sucker (Xvrauchen texanus) is currently proposed for listing as endangered. It is the Department of Energy's (DOE) responsibility to confer with the Service on any action which is likely to jeopardize the continued existence of any proposed species (50 CFR Part 402.10). Your biological assessment made the determination that the proposed action "may affect" the razorback sucker; however, the regulations require that the DOE determine whether the proposed action is likely to jeopardize the continued existence of the razorback sucker. Please submit your determination to this office for our concurrence.

We concur with your assessment that the proposed action would not affect the bald eagle (Haliaeetus leucocephalus) or black-footed ferret (Mustela nigripes). We appreciate your concern and effort in evaluating impacts the project may have on candidate species. Your report on the willow flycatcher (Empidomax trailii) was very informative and will be used to document the likelyhood of these birds being found in other areas of Colorado in similar habitats. 
This biological opinion addresses impacts of the proposal to Colorado squawfish, humpback chub, and bonytail chub. This opinion has been prepared in accordance with Section 7 of the Endangered Species Act (16 U.S.C. 1531 et seq.) and the Interagency Cooperation Regulations (50 CFR 402).

\section{Biological Opinion}

The depletion of 37 acre-feet of water from the Colorado River basin for the remedial action at the Naturita disposal site, with the inclusion of the Conservation Measures outlined below, is not likely to jeopardize the continued existence of the Colorado squawfish, humpback chub, or bonytail chub.

\section{Project Description}

The DOE proposes to consolidate contaminated uranium mill tailings which are associated with uranium milling activities which occurred adjacent to the city of Naturita, Colorado. These tailings and associated contaminated soil, over 800,000 cubic yards, would be disposed of in an approved contaminant area. DOE estimates 37 acre-feet per year of water will be needed to conduct this remedial action.

\section{Basis for Opinion}

Water depletions in the Upper Colorado River Basin have been recognized as a major source of impact to endangered fish species. Continued water withdrawal has restricted the ability of the Colorado River system to produce flow conditions required by various life stages of the fish. Impoundments and diversions have reduced peak discharges by 50 percent since 1942 while increasing flows by 21 percent in some reaches. These depletions along with a number of other factors have resulted in such drastic reductions in the populations of Colorado squawfish, humpback chub and bonytail chub that the Service has listed these species as endangered and has implemented programs to prevent them from becoming extinct.

\section{COLORADO SQUAWFISH}

The Colorado squawfish evolved as the main predator in the Colorado River system. The diet of Colorado squawfish longer than three or four inches consists almost entirely of other fishes (Vanicek and Kramer 1969). The Colorado squawfish is the largest cyprinid fish (minnow family) native to North America and, during pre-development times, may have grown as large as six feet in length and weighed nearly 100 pounds (Behnke and Benson 1983). These large fish may have been 25-50 years of age.

Based on early fish collection records, archaeological finds and other observations, the Colorado squawfish was once found throughout warm water reaches of the entire Colorado River Basin, including reaches of the upper Colorado River and its major tributaries, the Green River and its major tributaries, and the Gila River system in 
Arizona (Seethaler 1978). Colorado squawfish were apparently never found in colder, headwater areas. Seethaler (1978) indicates that the species was abundant in suitable habitat throughout the entire Colorado River basin prior to the 1850 's. Historically, Colorado squawish have been collected in the upper Colorado River as far upstream as Parachute Creek, Colorado (Kidd 1977).

A marked decline in Colorado squawish populations can be closely correlated with the construction of dams and reservoirs during the 1960 's, the introduction of nonnative fishes, and the removal of water from the Colorado River system. Behnke and Benson (1983) summarized the decline of the natural ecosystem. They pointed out that dams, impoundments, and water use practices are probably the major reasons for drastically modified natural river flows and channel characteristics in the Colorado River Basin. Dams on the mainstem have essentially segmented the river system, blocking Colorado squawfish spawning migrations and drastically changing river characteristics, especially flows and temperatures. In addition, major changes in species composition have occurred due to the introduction of nonnative fishes, many of which have thrived as a result of changes in the natural riverine system (i.e., flow and temperature regimes). The decline of endemic Colorado River fishes seems to be at least partially related to competition or other behavioral interactions with nonnative species, which have perhaps been exacerbated by alterations in the natural fluvial environment.

The Colorado squawfish currently occupies about 1,030 river miles in the Colorado River system ( 25 percent of its original range) and is presently found only in the upper Colorado River Basin above Glen Canyon Dam. It inhabits about 350 miles of the mainstem Green River from its mouth to the mouth of the Yampa River. Its range also extends 140 miles up the Yampa River and 104 miles up the White River, the two major tributaries of the Green River. In the mainstem Colorado River, it is currently found from Lake Powell extending about 201 miles upstream to Palisade, Colorado, and in the lower 33 miles of the Gunnison River, a tributary to the mainstem Colorado River (Tyus et al. 1982). Recent investigation found adult Colorado squawfish inhabit the San Juan River as far upstream as 163.3 miles above Lake Powell.

The life stages that appear to be most critical are from egg fertilization through its first year of life. It has been demonstrated that these phases of Colorado squawfish development are also closely tied to some specific habitat requirements. It is imperative that proper flows and temperatures are provided during these essential life stages. The conservation measures outlined below will help further investigate and meet the habitat requirements of the Colorado squawfish, thus offsetting project-related impacts and the likelihood of jeopardy for the species.

\section{HUMPBACK CHUB}

Humpback chub generally do not make migrational movements in the upper Colorado River and tend to reside throughout the year within a limited reach of river. Humpback chub are found inhabiting narrow, deep canyon areas, and are relatively restricted in 
distribution. They seldom leave their canyon habitat (Service 1982). While humpback chub are still occasionally found dispersed in the Green and Yampa Rivers, the only major populations of humpback chub known to exist in the upper Colorado River basin are located in Black Rocks and Westwater Canyons on the Colorado River. Conservation measures outlined below will contribute to providing proper habitat conditions for humpback chub, thus offsetting the likelihood of jeopardy for the species.

\section{BONYTAIL CHUB}

Little is known about the biological requirements of the bonytail chub, as the species greatly declined in numbers in the upper basin shortly after 1960 . Until recently, the Service considered the species extirpated from the upper basin; however, a recently collected specimen which exhibits many bonytail characteristics could indicate a small, extant population. It is thought that, should this species persist in the Colorado River, the preferred habitat would be larger river reaches in the Colorado River. Conservation measures outlined below will contribute to conservation efforts for the bonytail chub, thus offsetting the likelihood of jeopardy for the species.

\section{Conservation Measures}

On January 21-22, 1988, the Secretary of the Interior, the governors of Wyoming, Colorado, and Utah, and the Administrator of the Western Area Power Administration were cosigners of a Cooperative Agreement to implement the "Recovery Implementation Program for Endangered Fish Species in the Upper Colorado River Basin" (Recovery Program). An objective of the Recovery Program was to identify reasonable and prudent alternatives that would ensure the survival and recovery of the listed species while providing for new water development in the Upper Colorado River Basin.

The following excerpts are pertinent to the consultation because they summarize portions of the Recovery Program that address depletion impacts, Section 7 consultation, and project proponent responsibilities:

"All future Section 7 consultations completed after approval and implementation of this program (establishment of the Implementation Committee, provision of congressional funding, and initiation of the elements) will result in a onetime contribution to be paid to the Service by water project proponents in the amount of $\$ 10.91$ per acre-foot based on the average annual depletion of the project.... This figure will be adjusted annually for inflation.... Concurrently with the completion of the Federal action which initiated the consultation, e.g., ...issuance of a 404 permit, 10 percent of the total contribution will be provided. The balance...will be...due at the time the construction commences...." 
It is important to note that these provisions of the Recovery Program were based on appropriate legal protection of the instream flow needs of the endangered Colorado River fishes. The Recovery Program further states:

"...it is necessary to protect and manage sufficient habitat to support self-sustaining populations of these species. One way to accomplish this is to provide long term protection of the habitat by acquiring or appropriating water rights to ensure instream flows.... Since this program sets in place a mechanism and a commitment to assure that the instream flows are protected under State law, the Service will consider these elements under Section 7 consultation as offsetting project depletion impacts."

Thus, the Service has determined that project depletion impacts, which the Service has consistently maintained are likely to jeopardize the listed fishes, can be offset by (a) the water project proponents one-time contribution to the Recovery Program in the amount of $\$ 10.91$ per acre-foot of the project's average annual depletion, and (b) appropriate legal protection of instream flows pursuant to State law. The Service believes it is essential that protection of instream flows proceed expeditiously, before significant water depletions occur.

With respect to (a) above (i.e., depletion charge), the applicant will make a one-time payment which has been calculated by multiplying the project's average annual depletion ( 37 acre-feet) by the depletion charge in effect at the time payment is made. For fiscal year 1991 (October 1, 1990, to September 30,1991), the depletion charge is $\$ 10.91$ per acre-foot of the average annual depletion which equals a total payment of $\$ 403.67$ for this project. This amount will be adjusted annually for inflation on October 1 of each year based on the previous year's Composite Consumer Price Index. The Service will notify the DOE of any change in the depletion charge by September 1 of each year. Ten percent of the total contribution (\$40.37) or total payment, will be made to the National Fish and Wildlife Foundation (see Appendix A). The balance will be due at the time the construction commences. Fifty percent of the funds will be used for acquisition of water rights to meet the instream flow needs of the endangered fishes (unless otherwise recommended by the Implementation Committee); the balance will be used to support other recovery activities for the Colorado River endangered fishes.

\section{Conclusion}

This concludes our biological opinion on the impacts of proposed remedial action. This opinion was based upon the information described herein. If new information becomes available, new species listed, or should there be any changes in the total average annual amount of water depleted by this project ( 37 acre-feet per year) or any other project change which alters the operation of the project from that which is described in the biological assessment and which may affect any endangered or threatened species in a 
manner or to an extent not considered in this biological opinion (see 50 CFR 402.16), formal Section 7 consultation should be re-initiated. Section 7 consultation must also be re-initiated if there is failure to carry out the Conservation Measures upon which this opinion was based.

Thank you for your interest in conserving endangered species.

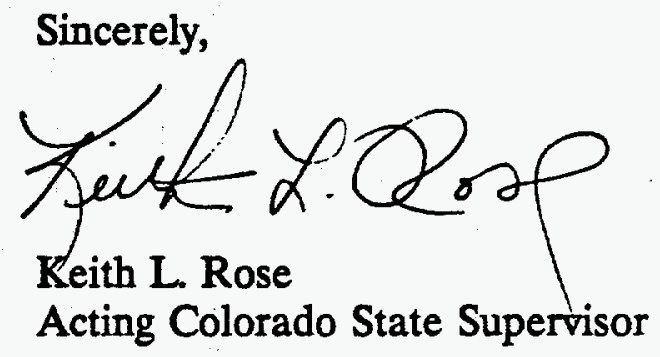
Attachment (Appendix A)
cc: CDOW, Grand Junction
EPA, Denver
FWS/FWE, Denver
FWS/FWE, Grand Junction
FWS/FWE, Salt Lake City
FWS/FWE, Washington, D.C. 


\section{REFERENCES}

Behnke, R.J., and D.E. Benson. 1983. Endangered and threatened fishes of the Upper Colorado River Basin. Ext. Serv. Bull. 503A, Colorado State University, Fort Collins, CO. 38 pp.

Kidd, G. 1977. An investigation of endangered and threatened fish species in upper Colorado River as related to Bureau of Reclamation Projects. Final report, Bureau of Reclamation, Salt Lake City. 36 pp.

Seethaler, K. 1978. Life History and Ecology of the Colorado Squawfish (Ptychocheilus lucius) in the upper Colorado River basin. Thesis, Utah State University, Logan, Utah.

Tyus, H.M., B.D. Burdick, R.A. Valdez, C.M. Haynes, T.A. Lytle, and C.R. Berry. 1982. Fishes of the Upper Colorado River Basin: Distribution, abundance and status. pp. 12-70. In: Miller, W.H., H.M. Tyus and C.A. Carlson, (eds) 1982. Fishes of the Upper Colorado River System: Present and Future. Western Division, American Fisheries Society, Bethesda, MD.

U.S. Fish and Wildife Service (Service. 1982. Colorado River Fishery Project Final Report. Part I (42 pp), Part II (356 pp), and Part III (342 pp). Prepared for the U.S. Bureau of Reclamation, Salt Lake City. April 1982.

U.S. Fish and Wildlife Service, 1987. Recovery Implementation Program for Endangered Fish Species in the Upper Colorado River Basin. U.S. Fish and Wildlife Service, Denver, Colorado. 82 pp.

Vanicek, C.D., and R.H. Kramer. 1969. Life history of the Colorado squawfish Ptychocheilus lucius and the Colorado chub Gila robusta in the Green River in Dinosaur National Monument, 1964-1966. Trans. AFS 98(2):193- 
Cooperative Agreement between

U.S. Department of the Interior

Fish and Wildife Service

and

National Fish and Wildlife Foundation

\section{Background}

Three species of fish that inhabit the Colorado River system have been federally listed as endangered: the Colorado squawfish, humpback chub, and bonytail chub. A fourth, the razorback sucker, is currently a candidate for listing. On January 21-22, 1988, the Governors of Utah, Wyoming, and Colorado, the Administrator of the Western Area Power Administration, and the Secretary of the Interior executed a Cooperative Agreement to implement the "Recovery Implementation Program for Endangered Fish Species in the Upper Colorado River Basin" (Recovery Program). The 15-year Recovery Program outlines an aggressive effort to recover the endangered fishes of the Colorado River in a manner that is consistent with Interstate Compacts and State water rights systems. The signing of the Cooperative Agreement also established an Implementation Committee whose purpose is to oversee the Fish and Wildlife Service's (Service) implementation of the Recovery Program. Members of the Implementation Committee include representatives of the States of Colorado, Wyoming, and Utah, the Service, the Bureau of Reclamation, the Western Area Power Administration, and representatives of the water development interests and environmental groups.

The cost for implementing the Recovery Program is estimated at $\$ 58.5$ million over the 15-year time frame. Contributions by proponents of water projects (Federal, State and private) are expected to provide approximately \$9-10 million of these funds, assuming full Compact development over the next 15 years. Water project proponents will make a one-time contribution to the Service in the amount of $\$ 10$ per acre-foot based on the average annual depletion of projects that complete consultation pursuant to Section $7(a) 2$ of the Endangered Species Act of 1973, as amended. Payment of the contribution will be specified in the biological opinion for each water project which causes a depletion of water from the Upper Colorado River system. Ten percent of the funds will be payable upon completion of the Federal action which initiated the consultation (e.g., issuance of a 404 permit); the balance will be due at the time construction commences or prior to the depletion becoming effective. Funds from these contributions are to be applied equally to flow acquisition and other priority recovery activities, unless otherwise directed by the Implementation committee.

In addition, the Recovery Program has a provision for the donation of funds from private parties, including conservation groups. Private donations would be used for priority recovery activities as agreed to by the donor, the Service, and/or the Implementation Committee.

The role of the National Fish and Wildlife Foundation (Foundation) was identified in the Recovery Program. Section 5.5 indicates that all contributed or donated funds accruing from the Recovery Program, regardless of source, will be placed in an interest bearing account, such as those administered by the Foundation, until such time as they are utilized in accordance with the Implementation Committee's approved annual work plan and budget. 


\section{Purpose and Objectives}

The purpose of this Cooperative Agreement is to establish a mechanism and procedures for (1) the transfer of funds contributed by water project proponents and private donors pursuant to the Recovery Program to the Foundation; and (2) the disbursement of said funds from the Foundation to accomplish Colorado River fishes recovery activities. This Cooperative Agreement will facilitate the accomplishment of recovery activities for the rare Colorado River fishes in an efficient and timely manner.

\section{Authorities}

Fish and Wildlife Coordination Act, 16 U.S.C. Sec. 661 ;

Fish and Wildlife Act of 1956, 16 U.S.C. Sec. 742f(a)(4); and

National Fish and Wildlife Foundation Establishment Act, 16 U.S.C. Sec. $3703(c)(6)$.

IV. Term

This Agreement shall take effect upon execution, with only subsequent contributed and donated funds being transferred to the Foundation, and will remain in effect until completion or termination of the Recovery Program, whichever occurs first. The term of the Cooperative Agreement that implements the Recovery Program is 15 years.

\section{Specific Obligations of the Parties}

To accomplish the purposes and objectives of this Cooperative Agreement, each party agrees to cooperate with the other to fulfill its obligations as herein provided.

\section{A. Service Obligations - The Service will:}

1. When this Agreement takes effect, inform water project proponents and potential private donors of the procedures for contributing funds to the Foundation, pursuant to the Recovery Program. Procedures for payment of the contributed funds will be specified in the Biological Opinion for each water project which causes a depletion of water from the Upper Colorado River system, and the Service is responsible for ensuring that private and State water project proponents make payment to the Foundation.

2. Identify, from the list of projects included in the Implementation Committee's approved annual work plan, those that should be funded by the Foundation with Colorado River contributed and donated funds. Use of these funds will be coordinated by the Service, on behalf of the Implementation Committee, with the Foundation. (Attachment 1 identifies the current process and schedule for development of the annual work plan by the Implementation Committee.)

3. Develop, in coordination with the Implementation Committee, requestsfor-proposals and/or scopes-of-work for work to be funded with Colorado River contributed/donated funds. 
4. Work closely with the Foundation to develop contracts for work to be funded with Colorado River contributed/donated funds.

5. Appoint a technical project officer for all contracts or projects carried out or funded under this Agreement.

6. Appoint an individual who will represent the Service in carrying out its obligations under this Agreement, including authorizing the expenditure of funds by the Foundation.

7. In cases dealing with disbursement of funds for acquiring water rights, provide the Foundation with written direction of the Service's Director or his designee, and a certified resolution of the Implementation Committee recommending allocation of the funds. The resolution will contain the following information:

a. The specific purpose for which the funds are being disbursed.

b. A detailed description of the water right to be acquired.

c. The owner of the water right.

d. The exact or maximum amount to be expended in acquiring the water right.

8. Coordinate and report upon activities of the Foundation with and to the Colorado River Implementation Committee, including providing an annual accounting to the Implementation Committee for all funds maintained, received, and/or expended pursuant to this Agreement.

9. Continue to maintain separate accounts for funds appropriated by Congress for the acquisition of water rights, and contributed/donated funds received prior to the implementation of this Agreement. Use of funds in these accounts will be coordinated by the Service, on behalf of the Implementation Committee, with those maintained by the Foundation under this Agreement.

B. Foundation Obligations - The Foundation will:

1. Serve as the Service's designated agent for accepting and administering contributed and donated funds acquired pursuant to the Recovery Program, and disbursing these funds as approved by the Service and the Implementation Committee.

2. Maintain these funds in a specific account, separate from other Foundation accounts. Interest accruing to this Foundation account will be used for the purpose for which the account was established.

3. Develop and/or issue, in coordination with the Service, contracts for work to be funded with Colorado River contributed/donated funds as identified in the approved Implementation Committee work plan.

4. Appoint an individual who will represent the Foundation in carrying out its obligations under this Agreement. 
5. Solicit and accept private donations to finance and implement recovery activities, including the acquisition of water rights, pursuant to the Recovery Program. This obligation is contingent upon approval of the Foundation's Board of Directors and the Service, and is separate from Congressional appropriations coming to the Service for acquisition of water rights.

6. Appoint a technical project officer for all contracts or projects carried out or funded under this Agreement.

\section{Financial Administration}

1. The Foundation will be reimbursed for actual expenses associated with carrying out its obligations under this Agreement (not to exceed two percent of the funds received each year). The Foundation will provide a quarterly statement which itemizes its expenses. Upon review (which will not exceed 30 days), the Service will authorize the Foundation to debit the contributed fund account to reimburse approved expenses.

2. The Foundation will prepare and submit to the Service a semiannual report by July 15 and December 15 of each year, which itemizes all funds

maintained, deposited, accrued, and disbursed from the account established pursuant to this Agreement.

VII. Project officers

For the Service (and on behalf of the Implementation Committee):

John Hami11, Program Director

Colorado River Endangered

Fishes Recovery Program

U.S. Fish and Wildiife Service

P.0. Box 25486, DFC

Denver, Colorado 80225

(303) 236-7398, FTS 776-7398

For the Foundation:

Whitney Tilt

Project Manager

National Fish and Wildlife

Foundation

18th \& C Streets, NW, Rm 2725

Washington, D.C. 20240

(202) 343-1040, FTS 343-1040

\section{Special Terms and Conditions}

1. The Foundation will, in coordination with the Service, select the most appropriate investment option for the contributed/donated funds. Primary consideration will be given to selecting extremely safe investments with the highest possible yield. Interest and/or dividends accruing to the account shall be available for the purposes for which the funds were contributed or donated.

2. Funds may be dispersed by the Foundation for purposes not included in the Implementation Committee's annual work plan at the written direction of the Service's designated representative for this Agreement and concurrence of the Chairman of the Implementation Committee. 


\section{Amendments}

Amendments to this Agreement may be proposed by either party, and shall become effective only upon being reduced to a written instrument executed by both parties.

\section{Termination}

This Agreement may be terminated by either party upon 90 days written notice to the other. Upon receipt of such written notice, the Foundation will provide an accounting of remaining funds and outstanding contractual obligations of funds. In the case of termination, the Service will make arrangements for transferring the funds administered by the Foundation to another entity, or renegotiate an alternative agreement with the Foundation.

\section{General Provisions}

The U.S. Fish and Wildlife Service General Provisions for Grant and Cooperative Agreements, as attached, shall be applicable to this Agreement.

In witness whereof, each party has caused this Agreement to be executed by an authorized official on the day and year set forth below their signature.

National Fish and Wildi ife

Foundatign

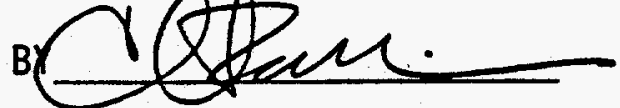

TITLE Excuten Ducitor

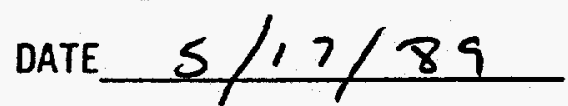

U.S. Fish and Wildlife Service

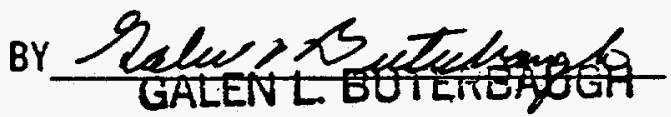

TITLE Regional Direotor

DATE JUN 141989 



\section{Process and Schedule \\ Colorado River Endangered Fishes \\ Annual Work Plan}

December 31 Each Principal Investigator provides a written summary of results of studies and identifies successes, shortcomings and plans for the next year. An oral presentation is provided at the Colorado River annual researcher's meeting in February.

March 15 Chairman of Technical Group sends out a request for preliminary proposals for new projects.

June 15 Technical Group meets to rank existing (ongoing) projects and preliminary proposals for new projects. Each project is ranked based on several factors, including:

a. consistency with the Recovery Program/Plans

b. degree of urgency (to avoid jeopardy)

c. essential for recovery

d. timeliness of study results

e. likelihood of success

f. relationship to other priority work

g. opportunity to do project now

h. quality of proposal

Recommendations are provided to the Management Group on the relative priority of funding existing and new (proposed) projects.

July 15 Management Group considers the recommendations of the Technical Group, determines available funding, and prepares draft work plan. Management Group transmits a draft work plan to Implementation Committee for review.

September 1 Implementation Committee meets to review and approve the annual work plan.

Sept-Dec Cooperators develop and/or issue requests for proposals, scopesof-work, and contracts for projects approved in the Implementation Committee's work plan.

January 31 Implementation Committee meets to review the status of projects contained in their annual work plan. 


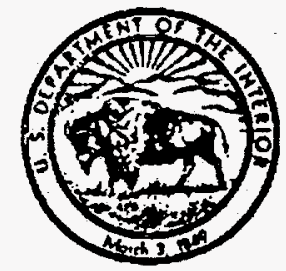

UNITED STATES DEPARTMENT OF THE INTERIOR

FISH AND WILDLIFE SERVICE

FISH AND WILDLIFE ENHANCEMENT

Weatern Colorado Sub-Office

529 251/2 Rand, Suite B-113

FTS 332-0351

Grand Junction, CO 81505-6199

FAX: (303) 245-6933

PHONE: (303) 243-2778

IN REPLY REFER TO:

FWE/CO:DOE:UMTRA

Mail Stop 65412 Grand Junction

February 25, 1991

Mark L. Matthews, Project Manager

Uranium Mill Tailings Remedial Action Project

Department of Energy

P.O. Box 5400

Albuquerque, New Mexico 87115

Dear Mr. Matthews:

This responds to your three letters dated February 7, 1991, regrading remedial action activities at the Gunnison, Maybell, and Naturita Uranium Mill Tailings sites.

Each of the above letters serve as a biological assessment for the razorback sucker (proposed for Federal listing on May 22, 1990), as required under Section 402.12 of 50 CFR 402. We concur with your conclusion that remedial action activity at each of the sites is not likely to jeopardize the continued existence of the razorback sucker. Further action under Section 7 of the Endangered Species Act is, therefore, not necessary for any of the above projects.

We appreciate your attention to endangered species issues. Please contact me if there are any questions.

Sincerely,

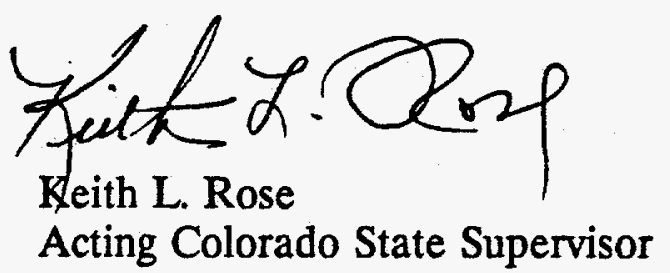

cc: FWS/FWE, Golden

FWS/FWE, Salt Lake City

CDOW, Grand Junction

CDOW, Montrose 
UNITED STATES DEPARTMENT OF THE INTERIOR

FISH AND WILDLIFE SERVICE

ECOLOGICAL SERVICES

Western Colorado Office

529 251/2 Road, Suite B-113

Grand Junction, CO 81505-6199

Phone: (303) 243-2778

FAX (303) 245-6933

IN REPLY REFER TO:

ES/CO:DOE-UMTRA

MS $65412 \mathrm{GJ}$

Apri1 20, 1993

Ms. Linda Ulland, Manager

Environmental Services

Jacobs Engineering Group, Inc.

5301 Central Avenue N.E., Suite 1700

Albuquerque, New Mexico 87108

Subject: Naturita UMTRA Project update

Dear Ms. Ulland:

This responds to your March 15, 1993 request for guidance regarding the need to update the biological assessment for the Naturita Colorado Uranium Mill Tailings Remedial Action (UMTRA) Project. As you state in your letter, the Fish and Wildlife Service provided a biological opinion dated December 11 , 1990 (FWE/GJ-6-C0-90-F-13) regarding this activity. Due to the need to evaluate other alternatives, the conservation measures included in that opinion to protect federally listed fish species were not implemented. Even though the current project description is not changed from that evaluated in the biological opinion, we believe it is necessary to re-evaluate the potential impacts of this project to federally listed and candidate species due to changes in the status of federally listed fish species, and some of the candidate species. Consequently, we are providing you the following list of federally listed and candidate species that may occur within the area of influence of the proposed project.

\section{FEDERALLY LISTED SPECIES}

\author{
Colorado squawfish \\ Humpback chub \\ Bonytail chub \\ Razorback sucker \\ Bald eagle \\ Black-footed ferret
}

Ptychocheilus lucius

Gila cypha

Gila elegans

Xyrauchen texanus

Haliaeetus leucocephalus

Mustela nigripes

We have provided Jacob's Engineering biological details regarding the federally listed fish species on numerous occasions; consequently, we are abbreviating this response. However, you should be advised that critical habitat for the federally listed fish species was proposed for designation on January 24, 1993 (Federal Register V58 No. 18). The proposal identifies 2,094 river miles of the Colorado river and its tributaries that are believed to have the essential biological and physical elements required for the conservation of the federally listed fish. The Fish and Wildlife Service will consider any depletion of water from the upper Colorado River basin as an adverse modification of this critical habitat, a conclusion which will require formal conferencing (50CFR402.10) by the Department of Energy with this 
office. The request for conferencing may be with the same letter requesting formal consultation due to the "may affect" determinations for the federally listed fish resulting from the depletion of water associated with this project.

Bald eagles are common winter visitors to Colorado. Statewide midwinter counts by the Colorado Division of Wildlife in 1990 documented 589 bald eagles at various rivers and reservoirs throughout the state. Bald eagles are commonly found near permanent water bodies such as streams, rivers, 1akes, and reservoirs. Tree height provides bald eagles with visibility and accessibility; diurnal perch trees are therefore usually taller than average, have a diameter of at least 12 inches, and are close to a river or reservoir shoreline (commonly within 33 yards). Winter night roost trees are generally larger than diurnal perches and may be further from a water body or food source. As bald eagles are known to fly up to 18 miles (greater distances may be traveled) from night roosts to feeding areas, they are also frequently seen searching upland habitats for prey or carrion. Over a period of time, bald eagles may be less faithful to wintering sites than breeding sites. Factors influencing their use of particular wintering areas include weather, quantity and concentration of food, availability of alternate locations, and human disturbance.

The Northern States Bald Eagle Recovery Plan classifies essential bald eagle wintering habitat in Colorado as areas that meet one of the following criteria: 1) Locations used annually for two weeks or longer by aduit or immature wintering eagles known (or strongly suspected) to be from nearby breeding areas. 2) Locations used annually by 15 or more eagles for two weeks or longer. 3) Locations used by bald eagles during periods of extremely harsh weather, when suitable feeding areas and night roost sites are limited in number (the minimum two week period of use does not apply to this criterion). Areas that are known to be used annually by bald eagles that do not exactly meet the above criteria may also be important.

We have learned that the proposal to alleviate wind blown contamination near the San Miguel River will consider the removal of cottonwood trees on approximately 40 acres. Your evaluation of impacts should determine whether the removal of the cottonwood trees will impact any of the above described bald eagle wintering habitat requirements. Any impact to essential wintering habitat described above will be considered a negative impact to the bald eagle. The Service would therefore expect the Department of Energy to conclude "may effect" to the bald eagle, and request formal consultation with this office. We encourage continued informal consultation with this office prior to conclusion of "may effect" to the bald eagle. There may be opportunities to incorporate project modifications to protect the bald eagle that would allow termination of the consultation process without the need to formally consult. We also suggest you contact Mr. Jerry Craig with the Colorado Division of Wildlife in Fort Collins (303-484-2836). Mr Craig may have more recent bald eagle inventory data for the project area.

As Jacob's Engineering knows, black-footed ferrets are dependent on prairie dogs. We believe there should be a new inventory of all project 1 ands to determine whether prairie dog colonies occur, and whether they will be 
disturbed by any phase of the project. The prairie dog inventory should occur on all lands within a one/half mile radius of all project feature boundaries.

\section{FEDERAL CANDIDATE SPECIES}

\author{
Ferruginous hawk \\ Loggerhead shrike \\ Northern goshawk \\ Southwestern willow flycatcher \\ White-faced ibis \\ Columbian sharptailed grouse \\ Roundtail chub \\ Flannelmouth sucker \\ Lupinus crassus
}

\author{
Buteo regal is \\ Lanius Iudovicianus \\ Accipiter gentilis \\ Empidomax trailii extimus \\ Plegadis chihi \\ Iympanuchus phasianellus columbianus \\ Gila robusta \\ Catostomus latipinnis \\ Paradox Tupine
}

The ferruginous hawk is the largest buteo in North America and is a category 2 listing candidate. It is a common summer resident of grass lands in Rio Blanco County, occasionally nests in pinon-juniper woodlands, and feeds on small mammals such as prairie dogs and rabbits. Human disturbance near active nest sites can result in nesting failure. A petition to 1 ist the ferruginous hawk was recently determined unwarranted by the Fish and Wildlife Service. However, there is a need to continue monitoring the status of this candidate species.

The loggerhead shrike is a category two listing candidate species. The shrike may be found in a variety of habitats below 6,000 feet elevation, including riparian areas and pinyon-juniper woodlands. The shrike is a fairly common summer resident and spring and fall migrant in Colorado. The loggerhead shrike may feed on large insects, small birds, or mice. The loggerhead shrike has shown significant population declines over much of its range. It has been extirpated from some areas in eastern Colorado, but appears stable in western Colorado. It is a rare to uncommon winter resident in western valleys north to Mesa County and on the southeastern plains north to the southern El Paso County. The loggerhead shrike has also been identified by the Partners in Flight international joint venture as a neotropical migrant worthy of attention.

The northern goshawk is a category two listing candidate. The goshawk is associated with aspen, ponderosa pine, and lodgepole pine between 7,500 and 11,500 feet elevation. Migrants and winter residents are seen on all types of coniferous forest, riparian forest, and occasionally shrublands. Goshawks feed primarily on other birds. The northern goshawk has also been identified by the Partners in Flight international joint venture as a neotropical migrant worthy of attention. Your project activities should be evaluated to determine whether impacts will occur to goshawks or their habitat. Pre-project surveys may be necessary.

The southwestern willow flycatcher is a category two listing candidate. It is a riparian obligate, usually found associated with Fremont cottonwood, Gooding willow, and tamarisk along slow moving watercourses. It is entirely insectivorous. There are no records of this species from Colorado, but it is 
believed to have nested in the southwestern part of the state historically. There are less than 1,000 breeding pairs throughout its range. Habitat destruction and fragmentation are the principal reasons for the species decline and threaten its continued survival. The willow flycatcher winters in Central America, and is therefore considered a neotropical migrant. It has been included in the Partners in Flight international joint venture to conserve neotropical migrants. Dr. James Sedgewick is a recognized species expert, who may be contacted at the National Ecology Research Center in Fort Collins (303-226-9466). Your evaluation of the project should determine whether riparian habitats will be impacted. If activities are planned in riparian habitats, surveys for the willow flycatcher may be warranted. Please contact this office for more details if surveys are desired. We are aware that you have conducted surveys for this species in the past and greatiy appreciate your attention to this bird. We would endorse your proposal to repeat surveys in the project area.

The white-faced ibis is a category two listing candidate. It is found in wet meadows, marsh edges, and reservoir shorelines, mostly below 6,000 feet elevation, but occasionally up to 9,000 feet. Ibis feed on crayfish, frogs, and grasshoppers. The ibis winters in California and Mexico.

The columbian sharptailed grouse is a category two listing candidate. It is a local resident in Routt and eastern Moffat counties, with smaller populations south to Montezuma county. The grouse is associated with shrublands and cultivated fields between 6,000 and 7,500 feet elevation. Populations have declined due to impacts to habitat. This grouse has declined in numbers and distribution throughout its range, and has been extirpated from California, Nevada, and Oregon. Its remaining stronghold is in western Colorado. Grouse are entirely insectivorous. For additional information on the species biology and distribution, contact Clait Braun with the Colorado Division of Wildlife in Fort Collins (303-484-2836).

The roundtail chub is a category 2 listing candidate. It is a native of the Colorado River basin and may reach 18 inches in length and weigh up to two pounds. Historically, it was the most common member of the genus Gila in the Colorado River basin, but has declined in distribution and abundance at some locales in recent years. In Colorado, it is found in the colorado, White, Yampa, Dolores, San Juan, and Gunnison rivers. The roundtail chub is a large river fish, and occupies slow moving waters adjacent to areas of faster water. Young-of-the-year prefer shallow river runs, while juveniles concentrate in river eddies and irrigation ditches. Young feed on small insects and algal films, while adults take both terrestrial and aquatic insects along with filamentous algae. Large chubs will take other fish. Spawning takes place over a gravel substrate in early summer in warm water as spring runoff is subsiding. The chub has declined in the Gunnison River, possibly due to coldwater releases from the Curecanti Project. For more information regarding this species biology and distribution, contact this office, or the Colorado River Fishery Project at 303-245-9319.

The flannelmouth sucker is a category 2 candidate species. It is restricted to larger streams and rivers in the middle and upper Colorado River basin, and is found only on the west slope of Colorado. This fish is found in all 
habitat types including riffles, runs, eddies, and backwaters. It feeds on invertebrates, and spawns in early May to early August. Competition with exotic species and/or cold water releases from reservoirs are reasons for their disappearance from the upper Gunnison River, and could impact their distribution elsewhere. Your project evaluation should include... For additional information regarding this species biology and distribution in Colorado, contact this office, or the Colorado River Fishery Project at 303245-9319.

We are aware that surveys were conducted for the Paradox lupine during preparation of the biological assessment in 1990. You should contact Dr. Lucy Jordan with this office to determine whether additional surveys are needed.

We have provided Jacob's Engineering numerous letters regarding the process required to satisfy section 7 of the Endangered Species Act; consequent7y, we do not believe it is necessary to remind Jacobs' Engineering of these requirements in this letter. However, we do request that Jacob's Engineering consider alternatives to the tentative proposal to remove approximately 40 acres of cottonwood trees from the San Miguel River riparian corridor. Even if there is no potential impact to wintering bald eagles, riparian corridors provide important habitat for numerous other species of wildlife.

Due to the water depletion associated with this project, it appears that formal consultation and conferencing will be required to bring this issue to closure under the requirements of the Endangered Species Act. We appreciate your attention to endangered species issues, and the effort you dedicate to the candidate species that may occur in the area. Please contact me or Bob Leachman if there are any questions.

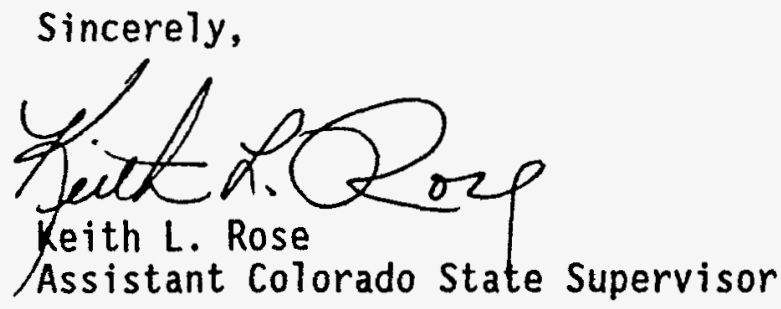

cc: FWS/Ecological Services, Golden

FWS/Ecological Services, Salt Lake City

CDOW, Montrose

BLeachman: natumtra.ltr:041993 